UCRL-ID-134253

\title{
Considerations on the Performance and Fabrication of Candidate Materials for the Yucca Mountain Repository Waste Packages: Highly Corrosion Resistant Nickel-Base and Titanium-Base Alloys
}

\author{
Alfred Goldberg \\ Edward N. Dalder
}

November 30, 1995

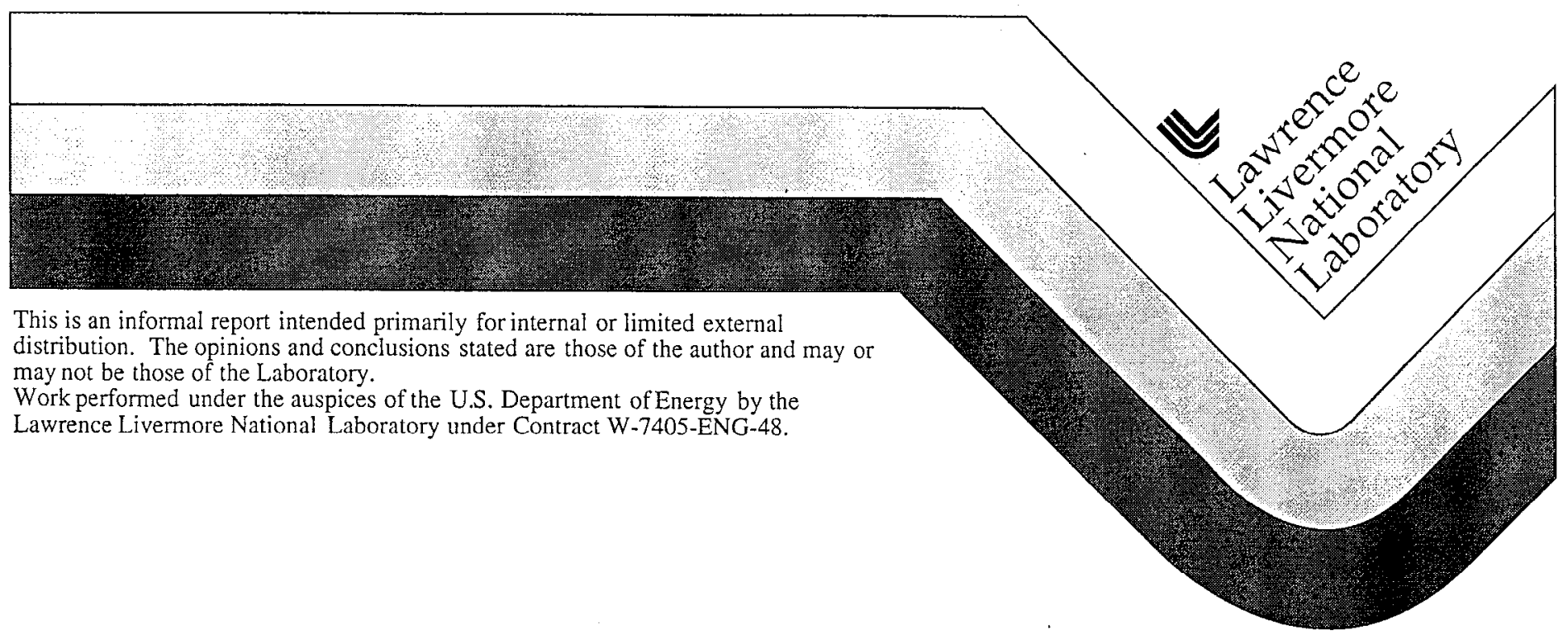




\section{DISCLAIMER}

This document was prepared as an account of work sponsored by an agency of the United States Government. Neither the United States Government nor the University of California nor any of their employees, makes any warranty, express or implied, or assumes any legal liability or responsibility for the accuracy, completeness, or usefulness of any information, apparatus, product, or process disclosed, or represents that its use would not infringe privately owned rights. Reference herein to any specific commercial product, process, or service by trade name, trademark, manufacturer, or otherwise, does not necessarily constitute or imply its endorsement, recommendation, or favoring by the United States Government or the University of California. The views and opinions of authors expressed herein do not necessarily state or reflect those of the United States Government or the University of California, and shall not be used for advertising or product endorsement purposes.

This report has been reproduced directly from the best available copy.

Available to DOE and DOE contractors from the Office of Scientific and Technical Information

P.O. Box 62, Oak Ridge, TN 37831

Prices available from (615) 576-8401, FTS 626-8401

Available to the public from the

National Technical Information Service

U.S. Department of Commerce

5285 Port Royal Rd.,

Springfield, VA 22161 
CONSIDERATIONS ON THE PERFORMANCE AND FABRICATION OF CANDIDATE MATERIALS FOR THE YUCCA MOUNTAIN REPOSITORY WASTE PACKAGES:

HIGHLY CORROSION RESISTANT NICKEL-BASE AND TITANIUM-BASE ALLOYS

\author{
Alfred Goldberg and Edward N. Dalder \\ Lawrence Livermore National Laboratory \\ Livermore, California 94551
}

November 30, 1995 


\section{CONSIDERATIONS ON THE PERFORMANCE AND FABRICATION \\ OF CANDIDATE MATERIAIS FOR THE YUCCA MOUNTAIN REPOSITORY WASTE PACKAGES}

\section{Background}

Among the metallurgical factors that affect the performance of a material in a given environment are alloy composition, alloy segregation, depletion of alloying elements, non-uniform microstructures, precipitation leading to an increase in susceptibility to corrosion as well as decreases in ductility, residual plastic deformation, and residual stresses. Precipitation often occurs preferentially at grain boundaries, causing depletion of critical elements in regions adjacent to these boundaries. Continuous grainboundary precipitates can lead to drops in ductility and toughness. The presence of non-metallic inclusions, if excessive and/or segregated, can also cause embrittlement. Segregation of alloying elements can result in localized galvanic action. Depletion of alloying elements as well as segregation can result in reductions in the concentrations of critical elements below those necessary to resist localized corrosion. Segregation and alloy depletion can also facilitate precipitation that could lead to embrittlement.

Compositional variations can arise from a number of souces, e. g., from the original cast structure, from joining sections made from different heats of the same alloy, from differences between filler metal and base metal, in fusion-welding, and from the cast microstructure in welded joints. Furthermore, depletion of alloying elements to below critical levels may occur in both the heat-affected and fusion zones of a weldment. Compositional variations, resulting from alloy partitioning and/or precipitation can also occur due to some thermal event, e. g., a faulty heat treatment, improper thermal cycles in welding, or elevated-temperature exposures in service.

In an as-fabricated component, compositional variations on a microscopic scale can be eliminated by an appropriate heat treatment, within the limitations of size and time of allowable exposure to the required temperature. By contrast, segregation occurring on a macro or larger scale, such as dendritic and coring segregation and through-thickness compositional gradients, can only be eliminated by a very lengthy, impractical, high-temperature homogenization treatment. In wrought materials, such a condition is 
indicative of insufficient hot deformation in the breakdown of the cast structure and/or of problems in the casting and/or solidification of the original ingot. Improper welding could also lead to such a condition. Residual plastic deformation, that may be present from a forming operation, can be a causative factor in many localizedcorrosion processes. Residual tensile stresses from welding may increase the susceptibility to stress-corrosion cracking and hydrogen-assisted cracking.

\section{Environment}

As a starting basis for the environment, one may consider the water composition from the J-13 Well, which is located near Yucca Mountain, and which draws water from the same tuffaceous rock that was selected for the repository. At the location of the well, this rock is below the water table and, thus, well below the proposed repository level which is to be located in an unsaturated zone about 213 to $426 \mathrm{~m}$ above the water table and about 91 to $366 \mathrm{~m}$ below ground. 1 The water is a sodium bicarbonate groundwater with a $\mathrm{pH}$ in the neutral to slightly alkaline range (Table 1).2 The corresponding $\mathrm{pH}$ at the time of this sampling was 7.41. Electrochemical corrosion measurements and corrosion rates were obtained in J-13 well water for a number of austenitic stainless steels as well as for Alloy 825.3 The results indicated that the corrosion potentials of these materials were insensitive to temperatures up to $90^{\circ} \mathrm{C}$. Furthermore, no significant differences in their corrosion rates were observed up to $100^{\circ} \mathrm{C}$, and with no indication of pitting. On increasing the chloride content of the well water, however, the corrosion potential of these materials became more negative as well as exhibiting enhanced susceptibility to pitting corrosion. Corrosion-rate studies in unmodified J-13 well water at temperatures from 50 to $150^{\circ} \mathrm{C}$ suggest that uniform oxidation and corrosion of $\mathrm{Fe}-\mathrm{Ni}-\mathrm{Cr}$ austenitic alloys will not limit container life in this environment. 1 The container life may be limited, however, for copper-based candidates for the same conditions.

The composition of the well water appeared to be a reasonable approximation to that of the vadose water. ${ }^{4}$ The composition of this water, however, will change with time, depending on the relative rates of dissolution of the rock-constituents. Also, due to the changing heat flux produced by radioactive decay, the various species in the water will undergo significant changes in concentration 
with time. Radiolytic products from gamma radiation will further modify the water composition. In addition, drill, diesel, and hydraulic fluids will be introduced into the repository with sulfides and carbonaceous material, encouraging the growth of microorganisms endemic to the site. Leaching of any engineered concrete or carbonaceous backfill can cause a significant increase in the $\mathrm{pH}$ value. Other constituents that may increase corrosion, such as sulfur, may also leach out from the materials used in engineered structures. Although corrosion tests have been performed in simulated J-13 well water, in view of the significant changes that might occur with time, the reliability of such tests in helping to accurately predict the long-time performance or even relative performance of candidate materials is questionable. For example, the evaporation of water in contact with the container could result in a significant increase in the concentration of the constituents present in any subsequent condensate formed at that location. On evaporation of $95 \%$ of $\mathrm{J}-13$ well water at $90^{\circ} \mathrm{C}$, the $\mathrm{pH}$ increased to 9.5 and the chloride concentration increased to $750 \mathrm{ppm} .{ }^{4}$

The rcliability of the candidate materials to perform in a predictable manner in any given environment depends not only on a knowledge of their performance in that environment, but also on the ability to control, during the production and processing of the materials and the fabrication of the containers, the various factors that may affect such performance. The credibility in predicting the performance of a particular material over the critical time period may be questionable because of the uncertainty in the changing conditions of the repository environment with time. The repository environment will experience numerous physical and chemical modifications due to changes in temperature, moisture content, chemistry, radiolytic products, and microorganisms. These changes will affect the performance of the various candidate materials. Therefore, a conservative approach must be taken in the selection and performance prediction of a material.

The expected performance of some of the candidate materials in the various anticipated environments, especially of the more corrosionresistant materials, is based on limited information frequently extrapolated from the behavior in laboratory tests that are usually performed in only partially-related environments. Performance of similar materials, although often limited, is also used as a guide. Concerns for the performance of high-level radioactive-waste containers, involving the choice of materials, the fabrication and 
closure of the containers, their emplacement and residence in the repository, and the possible environmental changes, have been addressed in some detail by McCright. ${ }^{5}$ With the ultimate goal being the prevention of radionuclide leakage, the performance of any selected material, the corrosion performance would be the major consideration in the overall selection of design, materials, fabrication, and final closure. Corrosion mechanisms, models, and scenarios have been presented that pertain to the various possible environments envisioned for the tuff repository. $1,6,7,8$

With an increase in knowledge of potential changes in the environmental conditions at the Yucca Mountain Site, with the introduction of alternative container designs, and with further evaluation of potential degradation modes, the selection of alternative candidate materials continues to be an evolutionary process. The task of developing procedures and/or recommendations for the fabrication and closure of the containers was initiated in FY86, with the major effort being performed by The Babcock \& Wilcox Co. under an LLNL subcontract.9,10,11 Alloy 825 and 70-30 cupronickel were the only materials of the current candidates that were evaluated in this task. Phase 1 was an engineering and screening study used to identify, assess, and rate a number of potential fabricating and closure processes for the containers. The study was on six candidate materials for a thin-wall container, about $10 \mathrm{~mm}$ thick, that was based on the current design at that time. Phase 2 was to produce and evaluate subscale mock-ups of a waste container as a basis for selecting the optimum fabrication and closure methods. In Phase 3, full-scale prototypes waste containers of the selected material were to be fabricated and sealed. Because of budget reductions, the project was terminated in the early stages of Phase 2 in FY89. Since the termination of this project, studies on the containers have been focused primarily on new container designs along with additional candidate materials, including materials having both more and less corrosion resistance than those which were previously considered.

\section{Current Barrier Options}

The container design for the waste package and the selection of container materials have yet to be finalized. A typical conceptual design that was recently considered proposes a closed metal cylinder about $65 \mathrm{~cm}$ diameter, 300 to $500 \mathrm{~cm}$ long and with a wall thickness 
of about $20 \mathrm{~mm} .{ }^{2}$ This wall thickness assumes the use of a highly corrosion-resistant material. The cylinder (or concentric cylinders if more than one barrier) might be fabricated from rolled-and-welded plate, or it might be cast or extruded. The bottom and top plates would likely be fabricated from rolled-plate and welded to the cylinder(s). All joints except those involved in the final closure could be annealed to relieve any fabrication stresses. Thus the region of final closure is of most concern in assuring the long-term integrity of the waste-package container.

Currently, several design options are being considered. One of these options envisions a metallic multi-barrier container having an outer barrier made from a corrosion-allowance material and an inner barrier consisting of a highly corrosion-resistant material.12 The outer barrier would have an allowable and predictable corrosion rate It would be of sufficient initial thickness, on the order of $102 \mathrm{~mm}$, to assure containment and structural integrity of the waste package as corrosion proceeds during its lifetime service of 10,000 years. The most significant degradation mode assumed for the outer barrier would be that of general corrosion. With a correction factor for pitting, this would allow for a calculated wastage of the material and a prediction of its service life. The corrosion-allowance material, however, must not undergo excessive wastage as it must provide for structural integrity and radiation shielding. The inner barrier would consist of a relatively thin wall, about $20 \mathrm{~mm}$ in thickness, which must be immune to general corrosion as well as highly resistant to both crevice and pitting corrosion. The potential for stress corrosion cracking and/or hydrogen embrittlement of any candidate material must also be evaluated in the final design. In the event that the outer barrier is breached, resulting in infiltration of liquid, it would hehave in an anodic manner to the nobler inner barrier and provide the latter with cathodic protection against corrosion.

A second design option would be to use a moderately corrosionresistant material for the outer barrier in the event that the environment is too aggressive for the corrosion-allowance material. In this option, the moderately corrosion-resistant barrier would be of sufficient thickness to provide the required strength and shielding or, alternatively, would be thinner and protect the heavier corrosionallowance material. 
A third option would use a moderately corrosion-resistant material as an additional barrier between the highly corrosion-resistant and corrosion-allowable barriers. The moderately corrosion-resistant material would have degradation characteristics of both the two other types of materials. As a fourth option, where the environment initially may be especially aggressive over a significantly length of time, it may be desirable to have the outer barrier consist of the highly corrosion-resistant material.

The relative importance of the various properties of a material will depend on the role and location of the corresponding barrier. The properties to be considered include: resistance to oxidation, resistance to uniform corrosion, resistance to localized attack, resistance to environmentally-assisted cracking, phase stability, resistance to mechanical embrittlement, strength, and ductility. Also, the canisters must withstand handling in transportation, emplacement, and retricval, as well as potential damage from falling rocks. It is proposed that the waste packages be emplaced horizontally in the drifts. The use of backfill in these drifts is yet to be decided. The backfill would absorb some of the shock from falling rock, if such an event were to occur. However, in being in contact with the container, the backfill may increase the chances for corrosion. For example, crevice corrosion could occur at contact locations; increased concentration of corrosive species can form in pockets of the backfill; leaching from the backfill material might contain constituents that could increase corrosion rates.

An important criterion in selecting the correct barrier option is the time period over which the container is in contact with water. This period is dependent on the thermal load from the radioactive-waste package. Two extremely different ranges of thermal loads are being considered, referred to as "high-thermal" and "low-thermal" loads, respectively.13,14 In both cases, radioactivity causes the temperature of the container and surroundings to rise above the boiling point of water producing a dry environment shortly after emplacement of the waste package. Vapor-phase corrosion is expected to be the dominant degradation mode during the first part of the containment period. 1 In the low-thermal load case, the temperature of the outer surface of the container will fall below $100^{\circ} \mathrm{C}$ within a relatively short period of time after the emplacement. (With the pressure being at slightly below one atmosphere, the actual boiling point of the water in the repository will be about $96^{\circ} \mathrm{C}$.) This drop in temperature will provide the potential for a wet environment and 
subject the waste package to wet corrosion for almost its life in the repository.

With the high-thermal load case, the corresponding temperature after emplacement is expected not to fall below $100^{\circ} \mathrm{C}$ for over a thousand years, providing a relatively dry environment during this period of time, and wastage is restricted to oxidation or vapor-phase corrosion. A thick outer barrier of carbon or alloy steel would suffice here. The maximum temperature in both cases is expected not to exceed $250^{\circ}$ C. ${ }^{2}$ The different environmental scenarios created by the two extremes in the thermal loads will dictate different material requirements for the two containers. For example, if penetration of the outer barrier occurred under the high-thermal-load conditions, and the temperature had dropped sufficiently to form condensate, radioactivity from the waste material would then have been substantially lowered so that the consequence of radiation leakage would be significantly reduced. Any subsequent breach of the inner, more corrosion-resistant, barrier could be tolerated. Under lowthermal-load conditions, with the earlier condensation of water and the possibility of earlier breaching of the barriers, the higher dose of radiation leakage would be less tolerable as compared to the highthermal-load case. Consequently, of the two scenarios, the more highly corrosion-resistant materials would be required for the lowthermal-load case.

\section{Current Candidate Materials}

The candidate materials currently being considered for the multibarrier containers at the Yucca Mountain repository are listed in Table 2.14 The corrosion-resistant materials consist of high nickelchromium-molybdenum alloys and titanium alloys. The high $\mathrm{Ni}-\mathrm{Cr}$ Mo alloys are separated into two groups, the superaustenitic stainless (Ni-rich) alloys and the Ni-Cr-Mo (Ni-based) alloys, distinguished primarily by their relative nickel and molybdenum contents. The titanium materials consist of Ti-Grade 12 and Ti-Grade 16, with near-alpha and alpha microstructures, respectively. The moderately corrosion-resistant alloys consist of two copper-nickel alloys, nickelbase Monel 400 and copper-base 70-30 cupronickel. Three lowcarbon steels are proposed for the corrosion-allowance materials, two being wrought products and the third a casting grade. One of the wrought products $(21 / 4 \% \mathrm{Cr}-1 \% \mathrm{Mo})$ corresponds to a pressure-vessel steel commonly used for nuclear reactors. Because information on 
some of the candidate materials may be limited, reference will also.. be made to materials of similar or nearly similar compositions to the candidate materials.

Candidate materials must have the best-predicted overall performance and have acceptable properties in the following categories: 1) resistance to possible modes of degradation, 2) fabricability and cost, 3) mechanical strength and toughness, and 4) metallurgical phase stability. ${ }^{1}$ Degradation modes listed are hydrogen embrittlement, hydrogen-induced degradation, uniform oxidation, uniform dissolution, pitting, crevice corrosion, stresscorrosion cracking, radiation-enhanced degradation, and microbiologically induced corrosion.

An expanded summary of the various properties, characteristics, and specifications of the candidate materials was presented in a recent report. 15 Highlights of this summary are presented here. Alloy 825 was proposed as the primary choice for the inner container. The alloy has adequate to excellent corrosion resistance in a number of environments, as well as having desirable mechanical properties, fabricability, and weldability. Alloy G-3, which contains more molybdenum than Alloy 825, was considered as a substitute for this alloy. The high chromium content in both alloys provided excellent resistance to highly oxidizing acidic conditions. In addition, the molybdenum will enhance the resistance to localized corrosion.

Alloys $\mathrm{C}-4$ and $\mathrm{C}-22$, containing concentrations of molybdenum considerably higher than are present in either Alloys 825 or G-3, were identified as alternatives to these two materials. Both Alloys C4 and C-22 have excellent resistance to corrosion, especially to stress-corrosion cracking, in a wide variety of aggressive environments. The two alloys are resistant to grain-boundary precipitation in the weld heal-affected zone. Because of the very low carbon contents and the presence of stabilizing elements, post-weld thermal treatments are not necessary. Wrought forms are usually supplied in the solution-annealed condition.

Two titanium alloys, Ti-Grade 12 and Ti-Grade 16, have outstanding corrosion-resistance, low density and sufficiently high strength, and are considered as a third alternative for the inner container. Owing to its palladium content, Ti-Grade 7 is the most corrosion-resistant titanium alloy available. Because of the Pd content (0.12 to 0.25\%), however, the alloy has a high cost that has limited its availability and 
use. Ti-Grade 16 was developed as a lower-cost substitute having about one-third the amount of $\mathrm{Pd}$ with still excellent corrosion resistance. Ti-Grade 12 contains small amounts of nickel and molybdenum which improve the corrosion resistance over that obtained with unalloyed grades of titanium. As with most titanium alloys, care must be taken to avoid surface contamination and hydrogen pickup during manufacture of the containers.

Average mechanical properties of the candidate corrosion-resistant alloys are given in Table 3. Limited data was available on Ti-Grade 16. Accordingly, properties on Ti-Grade 7 are included in the table, as these are expected to be close to those of Ti-Grade 16 .

For a mostly-dry environment, a low-carbon wrought steel, ASTM A 516, Grade 55, was selected as the primary choice for the outer containment barrier. The composition limits are close to those of AISI 1020. Thus, information on property values which are readily available for the 1020 steel, and that may be lacking for A 516, could be used for the latter material. The steel can be either hot or cold formed. Welding might require preheating, depending on thickness and temperature, as well as stress-relief after welding. A lowcarbon cast steel, such as ASTM A 27, Grade 70-40, was selected as an alternative to ASTM A 516. Castings should be heat treated by either full annealing, normalizing, normalizing and tempering or quenching and tempering. A second alternative candidate for the outer container is the low-carbon $21 / 4 \% \mathrm{Cr}-1 \%$ Mo pressure-vessel steel. This steel has a high degree of microstructural stability and excellent formability and weldability, as well as good resistance to aqueous corrosion and environmental cracking. The steel is used in either as-annealed, as-normalized-and-tempered, or as-quenchedand-tempered condition. A disadvantage of this steel is that it is subject to temper embrittlement in the temperature range of 300 to $600^{\circ} \mathrm{C}$ and, when so affected, is also susceptible to hydrogen embrittlement.

For a mostly-wet environment, Monel Alloy 400 was selected as a substitute for the steels. The alloy has excellent corrosion resistance to many environments, but it can be attacked in oxidizing solutions. It can readily be hot and cold worked; but it must be annealed in a reducing, sulfur-free atmosphere. It is readily machinable and weldable. A second alternative material and one that has been identified for fabricating the outer barrier of the defense high-levelwaste glass-disposal container is Alloy $\mathrm{C} 71500(70 \% \mathrm{Cu}-30 \% \mathrm{Ni}$ or 
cupronickel). The alloy is readily formable and weldable, and has excellent corrosion resistance to seawater and to processing fluids. A wide range of tensile properties is attainable with the $\mathrm{Cu}-\mathrm{Ni}$ alloys in either the annealed-and-cold-worked or heat-treated conditions. The two alloys are considered as being moderately corrosionresistant relative to the environment at the Yucca Mountain Repository.

In this report we will consider in greater detail below the three series of corrosion-resistant materials listed in Table 2. A subsequent report will be prepared to cover the moderately corrosion-resistant and corrosion-allowance materials also shown in this table.

\section{Superaustenitic Stainless and Ni-Cr-Mo Alloys}

The superaustenitic stainless (Ni-rich) steels, may be considered as an extension of the more conventional austenitic stainless steels. The added alloying content, especially nickel, leads to an increase in corrosion resistance. Increased chromium additions improves the corrosion resistance in oxidizing media. 16 The candidate materials selected in this group are Alloy 825 and Alloy G-3. These alloys are highly resistant to chloride-induced stress-corrosion cracking, even in high chloride concentrations. They may be susceptible to pitting and crevice corrosion. 5

The Ni-Cr-Mo (nickel-base) alloys are an extension of the superaustenitic stainless steels and possess further increases in corrosion resistance. Iron has been replaced by additional amounts of nickel and molybdenum. Two candidate materials were selected in this group, Alloys C-22 and C-4. Both groups contain small amounts of strong carbide formers and ultra-low carbon contents to minimize the possibility of sensitization ${ }^{\mathrm{n}}$. Molybdenum, with tungsten to a lesser extent, improves corrosion resistance in reducing media. ${ }^{16}$ The high nickel content increases the resistance to stress-corrosion cracking. The relatively high molybdenum content in the nickelbased alloys reduces the susceptibility to pitting and crevice attack that can occur in aggressive cnvironments with the supcraustenitic stainless alloys. In the most highly aggressive environments, Alloy C-22 appears to be more resistant than Alloy C-4; however, Alloy C4 , in possessing the better phase stability of the two alloys, may be more favorable for use in welding operations. The family of corrosion resistant alloys produced by Haynes International is shown 
in Table 4, which also gives the composition and some of the performance features of the alloys. 17 Also included is Alloy 59 which is relatively new 16 . Comments on the corrosion resistance of Alloy 59 are given in Appendix A.

\section{Phase Stability of Ni-Cr-Mo Alloys}

\subsection{Phase Relationships and Precipitation}

An extensive survey of phase stability and degradation modes of four $\mathrm{Ni}-\mathrm{Cr}-\mathrm{Mo}$ alloys, including Alloys $\mathrm{C}-4$ and $\mathrm{C}-22$, the current candidates, and Alloys C-276 and 625, was presented by Gdowski in 1991.18 The relative phase stability of the alloys was illustrated with reference to isothermal sections at several temperatures of the $\mathrm{Ni}-\mathrm{Cr}-\mathrm{Mo}$ equilibrium phase diagram. Locating the different commercial compositions on the isothermal sections was accomplished by assuming $\mathrm{Ni}, \mathrm{Cr}$, and $\mathrm{Mo}$ equivalents for the remaining elements. These equivalents were proposed by Cieslak et al as follows:

$$
\begin{aligned}
& \mathrm{Mo}_{\text {eq }}=\% \mathrm{Mo}+\% \mathrm{~W} \\
& \mathrm{Cr}_{\text {eq }}=\% \mathrm{Cr} \text {, and } \\
& \mathrm{Ni}_{\mathrm{eq}}=\% \mathrm{Ni}+\% \mathrm{Fe}+\sum \% \mathrm{X}_{\mathrm{i}},
\end{aligned}
$$

where $\Sigma \% \mathrm{X}_{i}$ is the total remaining alloy content not included in the other equivalents; percentages are in wt pct. ${ }^{19}$ The isothermal sections demonstrate the shrinking of the austenite-phase region as the temperature is lowered, with the relative movement of the commercial alloys either towards or into the two- and/or threephase regions containing intermetallic phases.

Figure 1 contains two isothermal Ni-Cr-Mo sections at 1250 and $850^{\circ} \mathrm{C}$, with Alloys C-4, C-22, and C-276 located based on the compositional equivalent values. ${ }^{19} \mathrm{As}$ can be seen, at $1250^{\circ} \mathrm{C}$ all four alloys are within the austenite field. At $850^{\circ} \mathrm{C}$, Alloys $\mathrm{C}-22$ and $\mathrm{C}$ 276 are within a two-phase $(\mu+\gamma)$ region, whereas Alloy C-4 and 625 are shown still to be well within the austenite region. At still lower temperatures, all four alloys have crossed over the austenite-phase boundary. In addition to the $\mu$ phase, and depending on the alloy, three other phases, P, $\sigma$, and, $\delta$ (delta ferrite) can be in equilibrium with the austenite phase. The $\mu, \mathrm{P}$, and $\sigma$ phases are intermetallics, each having a small range of solubility, consisting of different nickel, molybdenum, and chromium contents. The chromium and molybdenum contents, which can be partially substituted for by 
other elements present in the alloy such as tungsten, are significantly higher in these intermetallic phases than in the austenite phase.

Thus, if precipitation of the intermetallics occurs during processing, the austenite will be depleted in these elements.

Precipitation can occur during thermal cycles involved in processing and fabrication. Depending on the extent and morphology of the precipitation, the precipitates may lead to embrittlement, while the depletion in critical alloying elements near the precipitates may lead to a drop in resistance to corrosion. Grain-boundary precipitation will be especially detrimental. In addition to the intermetallics, carbides, containing chromium and/or molybdenum, may also precipitate and likewise lead to a degradation in properties. The types of carbides that form are dependent on the amounts of alloying elements present and the temperature at which they form. It appears that at least some small amounts of carbides are usually present, although in concentrations that may not be harmful. In addition, ordering ${ }^{\mathrm{b}}$ may also occur in these alloys during either slow cooling or on heating below about $600^{\circ} \mathrm{C}$ and cause degradation of properties.

\subsection{Aging Studies on Precipitation and Properties}

Studies on the effects of aging at low and intermediate temperatures in $\mathrm{Ni}-\mathrm{Cr}-\mathrm{Mo}$ alloys were recently reviewed by Gdowski.18 These studies showed that such aging can result in adverse changes in corrosion resistance and in mechanical properties. Of primary concern for the repository are the effects of long-term aging, (300 to 1000 years) at relatively low temperatures (50 to $260^{\circ} \mathrm{C}$ ), for which conditions studies have not be reported.

The studies reviewed by Gdowski were divided into two temperature ranges. Above $600^{\circ} \mathrm{C}$ precipitation of intermetallics and carbides occurs, while below $600^{\circ} \mathrm{C}$ the precipitation is preceded by

\footnotetext{
b Ordering refers to changing from a completely random arrangement of atoms at lattice-sites in the crystal structure between two or more species of atoms, to an ordered arrangement. This results from the attraction of unlike atoms, such that the nearest neighbors of one species are atoms of the second species. The ordered crystal structure may be either the same as or different from the random structure. In certain alloys, this occurs on lowering the temperature below some point (specific to the alloy), with the degree of ordering becoming more extensive as the temperature drops.
} 
segregation of certain elements and ordering in the alloy. Surface and grain-boundary segregation of minor alloying elements and impurity elements occurred on aging both above and below $600^{\circ} \mathrm{C}$. In the review, details on the sequences of aging and aging products are described for each alloy. Temperature-time-transformation (TTT) curves are presented for some of the aging products for Alloys C, C276 , and $\mathrm{C}-4$ for temperatures ranging down to near $500^{\circ} \mathrm{C}$.

Aging studies performed below about $500^{\circ} \mathrm{C}$, and as low as $100^{\circ} \mathrm{C}$, were performed on cold-worked Alloy C-276. Cold working accelerates the aging phenomena. Aging of the cold-worked alloy for one hour at temperatures ranging from 100 to $900^{\circ} \mathrm{C}$ developed significant differences in surface-impurity concentrations at the different aging temperatures. Other studies on aging with Alloy C276 indicated that surface segregation may cause it to become susceptible to hydrogen embrittlement. Effects of aging for times up to 8000 hours at $540^{\circ} \mathrm{C}$ on mill-annealed Alloys C-4 and C-276 were also presented in the review. ${ }^{18}$ Both alloys showed increase of about $100 \%$ in the yield strengths and about 40 to $45 \%$ in the ultimate tensile strengths. The corresponding decreases in tensile ductility elongation were from 62 to $34 \%$ for Alloy C-4 and from 65 to $28 \%$ for Alloy C276. Samples aged for the 8000-hour period were evaluated for corrosion resistance in boiling $50 \%$ sulfuric acid containing $42 \mathrm{~g} / \mathrm{l}$ ferric sulfate. The corrosion rate for C-276 increased from $5.7 \mathrm{~mm} / \mathrm{yr}$ for the mill-annealed condition to 67.5 $\mathrm{mm} / \mathrm{yr}$ for the aged condition; the corresponding values for Alloy C4 were 3.3 and $5.4 \mathrm{~mm} / \mathrm{yr}$, respectively. In contrast to the behavior of Alloy C-276, Alloy $\mathrm{C}-4$ showed virtually no detrimental effect on corrosion resistance due to aging.

A number of aging studies had been performed on Alloy $C$, indicating that minor alloying elements, especially silicon and carbon, accelerated the aging process, thereby increasing its susceptibility to embrittlement and corrosion. To reduce the aging kinetics for the precipitation of intermetallics and carbides, Alloy C-276 was developed as a modification of Alloy- $C$, wherein the maximum limits for carbon and silicon were reduced. Alloy C-276 was still readily susceptible to precipitation of the mu phase ${ }^{c}$ at high temperatures. For example, only six minutes at $900^{\circ} \mathrm{C}$ were required to precipitate sufficient $\mu$ phase to significantly alter the corrosion rate.20 This lack of stability of the austenite phase was attributed to the

c The mu phase is based on the crystal structure of $\mathrm{Fe}_{3} \mathrm{Mo}_{2}$. 
presence of tungsten which later was either reduced or eliminated. An electron theory of stability of alloy phases predicted that by eliminating tungsten, precipitation from the austenite phase would be greatly reduced. 21

Alloys C-4 and C-22 are modifications of Alloy C-276. In both alloys, the precipitation kinetics were further reduced relative to $\mathrm{C}-276$, with $\mathrm{C}-4$ being the least susceptible to microstructural changes. Thus, of the two candidates, Alloys C-4 and C-22, Alloy C4 , having the greater phase stability, would be more amenable to fusion-welding processes where avoidance and/or elimination of brittle precipitates can be a problem. Relative to C-276, tungsten is reduced in $\mathrm{C}-22$ and is eliminated in $\mathrm{C}-4$. The iron content is somewhat reduced, while the maximum carbon content is equally reduced in both alloys.

Reduction in both tungsten and iron, as well as in the carbon content, resulted in increasing the aging time for sensitization to occur in these alloys. To counteract tendencies for sensitization, titanium instead of vanadium is added to Alloy $\mathrm{C}-4$ as a carbide stabilizer. These compositional modifications, including maintaining a low silicon content $(0.08 \% \mathrm{max})$, eliminated the precipitation of intermetallics and significantly reduced the formation of carbides. The result was to greatly reduce the susceptibility to corrosion as depicted by corrosion tests performed on Alloys C-4 and C-276 following exposure period of up to 100 hours over the temperature range of 600 to $1000^{\circ} \mathrm{C} .18$

The effects of aging at relatively low temperatures on mechanical properties and corrosion have been evaluated for Alloys C-4, C-22, and $\mathrm{C}-276$ for times somewhat more relevant to repository performance. 22 Samples were exposed for 10,000 hours at 260 , 340 , and $425^{\circ} \mathrm{C}$. Corrosion rates were measured using ASTM G-28, Methods $A$ and $B,{ }^{d}$ with exposures of 24 hours for both methods Aged samples were compared with the original mill-annealed conditions. Charpy impact ${ }^{\mathrm{e}}$ and tensile-yield properties were reported. The

\footnotetext{
d Method A consists of exposure to a boiling solution of $42 \mathrm{~g} / \mathrm{l}$ of $\mathrm{Fe}_{2}\left(\mathrm{SO}_{4}\right)_{3}$ in $50 \%$ $\mathrm{H}_{2} \mathrm{SO}_{4}$. Method $\mathrm{B}$ consists of exposure to a boiling solution of $23 \% \mathrm{H}_{2} \mathrm{SO}_{4}-1.2 \% \mathrm{HCl}$ $1 \% \mathrm{FeCl}_{3}-1 \% \mathrm{CuCl}_{2}$.

e Charpy impact tests are used to evaluate notch toughness. Small bar samples, notched on one face are fixed in a guide (in an impact testing machine) and
} 
authors conclude that there is no long-term, low-temperature aging effect on either mechanical properties or corrosion resistance on these three alloys.

These studies were later extended to include higher aging temperatures and longer aging times. 20 Samples that were aged for 20,000 hours at 260,340 , and $425^{\circ} \mathrm{C}$ did not show any changes in the above properties. Additional aging at $425^{\circ} \mathrm{C}$ did result in an increase in strength and a drop in ductility, but, no change in the corrosion rate. Corrosion rates did not increase until after at least an aging period of over 38,000 hours at $482^{\circ} \mathrm{C}$. On aging at $425^{\circ} \mathrm{C}$ for up to 20,000 hours, Alloy $\mathrm{C}-22$ gave the lowest corrosion rate when corrosion tested according to ASTM G-28, Methods A and B; Alloy C4 had significantly the highest corrosion rates using ASTM G-28 B, while Alloys $\mathrm{C}-4$ and $\mathrm{C}-276$ gave similar corrosion rates using ASTM G-28 A. Exposure of Alloy C-276 for over 53,000 hours at $538^{\circ} \mathrm{C}$ resulted in a significant drop in toughness and an increase in corrosion rate from 4.3 to $102 \mathrm{~mm}$ per year. This was attributed to grain-boundary precipitation of $\mathrm{M}_{6} \mathrm{C}$. An ordered $\mathrm{A}_{2} \mathrm{~B}$ phase ${ }^{\mathrm{f}}$, which is believed to be $\mathrm{Ni}_{2}(\mathrm{Cr}, \mathrm{Mo})$, was also detected and can account for a slight increase in the corrosion rate. The formation of this phase was the only change that was observed in Alloy $\mathrm{C}-4$ following exposure at $538^{\circ} \mathrm{C}$ for nearly 46,000 hours. The exposed alloy showed only a moderate increase in corrosion rate, namely, from 3.2.to $10.2 \mathrm{~mm}$ per year. 20 Extrapolating their observations, the authors predicted that at $260^{\circ} \mathrm{C}$ it would require 400,000 years to develop the ordered $\mathrm{A}_{2} \mathrm{~B}$ phase and still longer to precipitate the carbide phase. As a result of their aging studies, the authors conclude that of the three alloys, $\mathrm{C}-22$ is the best as a radioactivewaste-container material.

\section{Comments on the Corrosion Resistance of Candidate $\mathrm{Ni}-\mathrm{Cr}-\mathrm{Mo}$ Alloys}

Alloys $\mathrm{C}-4$ and $\mathrm{C}-22$ have exceptionally high resistance to corrosion in both reducing and oxidizing media for a wide variety of corrosive environments. Both are highly resistant to pitting and crevice corrosion and to stress-corrosion cracking. ${ }^{23,24}$ The claim is made

impacted on the face opposite the notch. The notch can be V-shaped, Ushaped, or key-hole shaped.

${ }^{f}$ In the formula $\mathrm{A}_{2} \mathrm{~B}, \mathrm{~A}$ refers to the host element, such as $\mathrm{Ni}$ in this case, and $\mathrm{B}$ to one or more alloying elements. 
that Alloy $\mathrm{C}-22$ has the best overall corrosion resistance of all $\mathrm{Ni}-$ Cr-Mo alloys available.23 The superiority of Alloy C-22 was illustrated by comparing corrosion rates of Alloys C-22, C-276, C-4, and 625 for a number of different aggressive media. The data from one of the examples (Table 5) show that Alloy C-22 is superior in all cases, with Alloy $\mathrm{C}-276$ being next best and $\mathrm{C}-4$ being third best.23 The same order of merit was shown for the "critical pitting temperatures" (above 150, 150, 140, and $90^{\circ} \mathrm{C}$ ) and "critical crevicecorrosion temperatures" ${ }^{\mathrm{g}}\left(102,80,50\right.$, and $\left.50^{\circ} \mathrm{C}\right)$. The test solution consisted of $4 \% \mathrm{NaCl}+0.1 \% \mathrm{Fe}_{2}\left(\mathrm{SO}_{4}\right)_{3}+0.01 \mathrm{M} \mathrm{HCl}$ with an acidity of $\mathrm{pH} 2$. It is assumed that the test materials were in the annealed condition. Because of the greater susceptibility of Alloy C-276 to precipitation than of Alloy $\mathrm{C}-4$, it is expected that Alloy $\mathrm{C}-4$ will exhibit better corrosion resistance than Alloy C-276 on exposure of the as-welded conditions in these media.

The benign nature of welding on the resistance to corrosion for Alloy $\mathrm{C}-4$ is illustrated in Table 6 , where the corrosion rates of the aswelded, annealed, and aged conditions are compared for eight different test media.24 Both alloys, being highly resistant to the formation of grain-boundary precipitates in the weld heat-affected zone, are suitable for service in the as-welded condition in most corrosive environments. Intermetallic precipitates associated with other $\mathrm{Ni}-\mathrm{Cr}$-Mo alloys that form in the range of 650 to $1100^{\circ} \mathrm{C}$ have not been detected in Alloy $\mathrm{C}-4$. Fine particles of $\mathrm{M}_{6} \mathrm{C}$ carbides can form, but their damaging effect is minimal. More detailed discussions on the relative corrosion resistance of $\mathrm{Ni}-\mathrm{Cr}-\mathrm{Mo}$ alloys are presented in Appendix A.

\section{Technical Information and Fabrication Guidelines on Corrosion-Resistant Ni-Cr-Mo Alloys}

Technical information and fabrication guidelines for a number of corrosion-resistant $\mathrm{Ni}-\mathrm{Cr}$-Mo alloys are available in publications provided by Haynes International 23,24,25 and the Nickel Development Institute 26 . The following presentation is largely based on the information provided in these publications. Some of this

\footnotetext{
$g$ The critical pitting and crevice-corrosion temperatures refer to the maximum temperature in each case at which no evidence of either corrosive action occurs under the test conditions studied. Typically, tests are performed at increasing temperatures in intervals of $5^{\circ} \mathrm{C}$ until a temperature is reached where evidence of corrosive activity is seen.
} 
information was also presented in a recent LLNL report. ${ }^{15}$ The focus here will be on Alloys C-4 and C-22.

Wrought forms of the $\mathrm{Ni}$-Cr-Mo corrosion-resistant alloys are furnished in the solution-heat-treated condition unless otherwise specified. The alloys can be rolled, forged, hot upset, impact extruded, and cold formed. They are available in the form of sheet, strip, plate, bar, wire, billet, tubing, and covered electrodes. Although the alloys tend to work harden rapidly, they can be successfully deep-drawn, spun, press-formed, and punched.

\subsection{Heat Treatment}

In general, the only heat treatment that is acceptable for these alloys is a solution anneal. The solution-anneal heat treatments of Alloys $\mathrm{C}-4$ and $\mathrm{C}-22$ are performed by soaking at temperatures of 1066 and $1121^{\circ} \mathrm{C}$, respectively, followed by rapid cooling. Water quenching is the preferred method; however, rapid air-cooling can be used on sections thinner than $9.5 \mathrm{~mm}$ (3/8 inch). The solution anneal will place the alloys in the optimum condition with respect to mechanical properties and corrosion resistance. Following all hotforming and most cold-forming operations, a solution anneal should be done to restore these properties. Stress-relief temperatures commonly used for iron-based materials and some nickel-based alloys are not to be used, as heating to such intermediate temperatures will promote detrimental precipitation. The effects of cold working from various forming operations can be eliminated by holding a minimum of 5 to 10 minutes, depending on gage size, at the solution-anneal temperature. The holding time should be started when the entire section is at the proper temperature.

The following precautions are to be taken in heat treating:

- Remove any grease, graphite, paints, and all other foreign materials from surfaces. Avoid imbedding iron particles if wire brushing is used in the cleaning.

- Avoid any possibility of carburization; use neutral to slightly oxidizing atmosphere. Reducing atmospheres must not be used in order to prevent the possibility of carbon or hydrogen contamination.

\subsection{Hot Working/Forming}


Characteristics of the Ni-Cr-Mo alloys that must be considered during hot-working operations include relatively low melting temperatures, high hot strength, high strain-rate sensitivity, low thermal conductivity, relatively high strain-hardening coefficients, and a rapid increase in strength with a drop in temperature in the hot-working range. The alloys have a relatively narrow hot-working range with start-to-finish temperatures of $1177^{\circ} \mathrm{C}$ down to $954^{\circ} \mathrm{C}$ for Alloy C-4 and $1232^{\circ} \mathrm{C}$ to $954^{\circ} \mathrm{C}$ for Alloy C-22. Because of this, moderate reductions per pass with frequent reheating is recommended. Care must be taken during hot working to avoid excessive adiabatic heating, as well as excessive loss of heat, by controlling the rate of billet or ingot reduction. Care must also be taken to avoid furnace overheating. In addition, the original cast structure must be completely refined during the breakdown stage, that is, before the final hot-rolling or hot-forging operation. Following hot working, the alloys must be solution annealed for optimum corrosion resistance. The furnace atmosphere must be sulfur-free and slightly oxidizing.

\subsubsection{Forging}

The following guidelines are recommended for forging:

- Soak billets or ingots at least 12 minutes per $\mathrm{cm}$ of thickness at forging temperature. Do not raise the furnace temperature above the forging-temperature range.

- Use a calibrated optical pyrometer to verify temperature.

- Avoid direct flame impingement on the stock.

- Turn stock frequently to present the cooler side to the furnace atmosphere and heat source.

- Forge immediately following withdrawal from the furnace.

- Use reductions of between 25 and $40 \%$ per pass, which are sufficient to maintain as much internal heat as possible, thus reducing the number of reheatings and minimizing grain growth.

- Avoid making radical changes in the cross-sectional shape during the initial reduction stages.

- Condition (remove) cracks or tears developed during forging. This can usually be done at intermediate stages between forging sessions.

- Limit hot-upsetting to stock with aspect ratios (length to diameter) no greater than three to one (3:1), with the temperature in the upper end of the hot-working range. 


\subsubsection{Hot Rolling}

The guidelines listed for forging are generally applicable for hotrolling operations with the following additions and modifications:

- Use moderate reductions of 15 to $20 \%$ in area per pass.

- Use rolling speeds of 6100 to 9100 surface $\mathrm{cm}$ per minute.

- Use frequent reheats to maintain temperature of the stock in the hot-working range.

- Soak workpiece thoroughly at the hot-working temperature before starting the rolling operations.

\subsubsection{Other Hot-Forming Operations}

The forming of plate into components such as dished heads is normally done by cold pressing or spinning with intermediate anneals. The shaping of large sizes and heavy sections, will require hot forming. The following additional guidelines are recommended for such hot forming operations:

- Set furnace temperature intermediate between the solution-anneal and finish forging temperatures $\left(1066^{\circ} \mathrm{C}\right.$ and $954^{\circ} \mathrm{C}$ for Alloy $\mathrm{C}-4 ; 1121^{\circ} \mathrm{C}$ and $954^{\circ} \mathrm{C}$ for Alloy $\mathrm{C}-22$ ).

- Do not allow the temperature to drop below the lower hotworking temperature during hot forming.

- Avoid excessive surface chilling of the component by using preheated dies.

\subsection{Cold Working/Forming}

Cold working is the preferable method of forming these alloys. 25 Depending on the severity of the deformation, the alloys may require a number of intermediate forming stages to produce the final shape. For mild forming operations, the mill-annnealed condition, which is a solution anneal, will generally have sufficient ductility without having the need for intermediate heat treatments. Where required, intermediate as well as final anneals should be performed at the solution-annealing temperature. Critical cold reductions in the range of about 2 to $10 \%$ must be avoided if solution annealing is specified. This precaution is to avoid the possibility of abnormal grain growth during subsequent annealing. The presence of cold work does not affect either uniform or pitting corrosion, but, heavy residual cold work can increase the susceptibility to stresscorrosion cracking in certain environments. ${ }^{25}$ Lubrication during 
forming is important and various lubricants are recommended, depending on the type and severity of the cold-working operation. Care must be taken to remove the lubricants or other foreign materials from the surface of the formed part prior to annealing, otherwise the mechanical and corrosion properties will be adversely affected. Lubricants that contain lead, zinc, or sulfur must be avoided as these elements tend to embrittle the Ni-Cr-Mo alloys.

The following guidelines are recommended for cold-working operations:

- Avoid reductions in the range of 2 to $10 \%$ if the reduction is to be followed by a solution anneal, otherwise abnormal grain growth may occur on such annealing.

- Solution anneal components with outer-fiber strains greater than about 7 to $10 \%$.

- Perform a series of successive forming operations with intermediate anneals when relatively severe cold deformation is required to form the part; otherwise, cracking may occur.

- Remove scale by pickling or by mechanical means following an anneal prior to the next forming operation .

- Lubricate with lard oil or castor oil for mild forming operations. These oils are easily removable.

- Lubricate with metallic soaps, chlorinated oils, or sulfochlorinated oils for relatively severe forming operations. If sulfochlorinated oils are used, carefully clean workpiece in a degreaser or alkaline cleaner.

- Avoid lubricants that contain either white lead, zinc compounds, or molybdenum disulfide as they are difficult to remove, and they will embrittle the alloy during subsequent heat treatment.

\subsubsection{Cold Spinning}

Spinning can be performed cold if excessive deformation is not required. There are two basic forms of spinning. In manual spinning, no appreciable thinning of the metal occurs. In power (shear) spinning, the metal is thinned as a result of the shear forces. The control of quality, including freedom from wrinkles and scratches as well as dimensional accuracy, is largely dependent on operator skill. The main parameters that should be considered are speed, feed rate, lubrication, alloy, strain-hardening characteristics, tool material, tool design, tool finish, and machine power. Lubrication must be 
used in all spinning operations. During continuous operation, temperature changes of the mandrel and spinning tool may necessitate adjustment of pressure, speed, and feed. Mandrels must be hard, wear resistant, and fatigue resistant, and should have a finish no rougher than $1.27 \mu \mathrm{m}$ (50 microinches) and preferably 0.38 to $0.76 \mu \mathrm{m}$ (15 to 30 microinches).

For cold-spinning operations, the following additional guidelines and modifications apply:

- Make trial runs to determine speed and feed rate.

- Apply lubricant to the blank prior to loading in the machine.

- Add additional lubricants as needed during the operation.

- Flood workpiece and tools during spinning with coolant such as an emulsion of soluble oil in water.

- Do not use chlorinated or sulfurized lubricants, as spinning may burnish the lubricant into the surface, with embrittlement on subsequent heat treatment.

\subsection{Machining and Grinding}

According to Haynes International, the Ni-Cr-Mo corrosion-resistant alloys are considered as being moderate to difficult to machine.25 They work harden rapidly on machining, generate high heat during cutting, and may weld to the cutting-tool surface. Because of their high shear strength, they offer high resistance to metal removal. The alloys can be machined using conventional production methods at satisfactory rates. The alloys can be cut using any conventional plasma-arc-cutting system. Grinding wheels and corresponding coolants or lubricants recommended for different types of grinding operations are listed in Table 7. Recommended tool types and corresponding coolants for different machining operations are listed in Tables 8 and 9.

Guidelines on machining of $\mathrm{Ni}-\mathrm{Cr}$-Mo alloys are:

- Plasma-cut workpiece using a mixture of argon and hydrogen gases.

- Substitute nitrogen for hydrogen gas with a slight deterioration of cut quality.

- Avoid use of shop air or any oxygen bearing gases.

- Grind finish when very close tolerances are required.

- Use rigid machine, overpowered as much as possible.

- Maintain workpiece and tool held rigid and minimize tool overhang. 
- Maintain tools sharp at all times; sharpen at regular intervals.

- Use carbide-tipped tools for most operations; high-speed tools can be used, giving lower production rates.

- Use positive rake angles for most machining operations.

- Use heavy, constant feeds to maintain positive cutting action.

- Use soluble oils lubricants, especially when using carbide tooling.

\subsection{Welding}

Welding guidelines, which are presented here for the welding of NiCr-Mo alloys, are largely taken from information provided by Haynes International 25 and the Nickel Development Institute 26. Welding processes that are commonly used with these corrosion-resistant alloys are gas tungsten-arc, gas metal-arc, and shielded metal-arc welding. Other welding procedures such as plasma-arc, resistance, friction, laser-beam, and electron-beam welding can also be used with these alloys. These methods are being used with increasing frequency. 26 Plasma-arc cutting is commonly used to cut plate and to make weld-joint preparations.

Oxyacetylene welding and submerged arc welding are not to be used. The first method has a high possibility of carbon pickup from the flame. The second method can result in hot cracking, chromium loss, silicon pickup, and excessive heat input. Oxyacetylene cutting should not be used.

A table showing the relative merits of a number of welding processes that had been considered for closure of containers for the Yucca Mountain Repository is reproduced as Table 10.9 At that time, of the nickel-rich alloys, only Alloy 825 was a candidate. The need to adapt any of the selected processes for remote-control (hot cell) operations is an important consideration. Two of the methods, gas metal-arc welding and shielded metal-arc welding, that are recommended for welding of nickel-based alloys were not included in that evaluation. The relative merits in using these two methods as well as the gas tungsten arc welding method are presented in Table 11. The contents are based on information provided in bulletins published by Haynes International 25,26

Liquid nickel-based alloys have relatively high viscosities, leading to defects associated with lack of fusion and shallow penetration in 
multipass weld joints. To ensure sound welds with proper weldbead junctions, care must be taken with joint design and weld-bead placement. The welding arc and filler metal must be manipulated so as to place the molten metal where it is needed. Although a weave technique is recommended to manipulate the viscous liquid-weld metal, wide welding-weave beads are not recommended. Stringerbead torch-welding techniques, with some electrode manipulation, are preferred. The alloys have a tendency to crater-crack; therefore, grinding of starts and stops is necessary. Butt welds should be fullpenetration welds to produce full strength and optimum performance in corrosive environments. Fillet welds need not be full-penetration welds as long as the sides and ends are welded closed to seal off voids, which favor the development of crevice corrosion.

Cleanliness is important in the welding of these alloys. 27 Embedded iron, which may arise in using iron-containing abrasives, can lead to localized corrosion. Contamination by grease, oil, corrosion products, and low melting-point elements such as lead and sulfur can lead to severe cracking problems. ${ }^{25}$ Examples and sources of contaminating elements are listed in Table 12.26

Guidelines for welding of Ni-Cr-Mo alloys are:

- Control heat input in low to moderate range for the joint design being welded.

- Avoid wide welding weave beads.

- Use gas tungsten arc welding for depositing root pass in square butt or single vee joints.

- Make groove openings wide enough to allow proper torch or electrode manipulation and proper placement of the weld bead. This is necessary because of the high viscosity and low penetration of the liquid nickel-based weld metal.

- Use stringer bead torch/welding techniques with some electrode manipulation.

- Design joints and place weld beads to assure that sound welds with proper weld-bead tie-ins are achieved.

- Grind starts and stops to deter crater cracking.

- Take necessary steps to maintain cleanliness.

- Do not use oxyacetylene welding or submerged arc welding.

- Grind all thermally cut surfaces to bright, shiny metal prior to welding.

- Thoroughly clean welding surfaces and adjacent regions with appropriate solvent to remove all foreign matter prior to welding. 
- Preheat to room temperature to avoid condensation if taken from a cold environment.

- Maintain interpass temperatures below $93^{\circ} \mathrm{C}$.

- Wire-brush with stainless steel brushes between passes. If present, remove slag by chipping/grinding prior to wire brushing. If oxygen- or carbon dioxide-shielding gases are used, apply a light grind prior to wire brushing.

- Use fixturing/clamping and balance weld passes about the neutral axis (where possible) to minimize distortion.

- Avoid making concave-shaped root-pass weld beads, as this leads to cracking of the root pass.

- Use backing gas (100\% argon) for the root pass when using either gas tungsten-arc or gas metal-arc welding.

- Store exposed shielded-metal arc process electrodes in ovens at 120 to $200^{\circ} \mathrm{C}$ to drive off moisture from the electrodecoating.

- Do not use wash passes or cosmetic welds because of the risk of weld cracking or reduced corrosion resistance.

- Prevent entrainment of air into the protective gas shield.

- Avoid stress relieving in the range of 500 to $700^{\circ} \mathrm{C}$; if a stress-relief is required, use a solution heat-treatment.

In comparing the tensile properties of as-welded weldments with the base metals of Alloys C-4 and C-22, only minor differences are observed between the ultimate tensile values. By contrast, the welding often results in a significant increase in the yield strengths and a corresponding drop in ductility. ${ }^{23,24}$ Some examples of this are shown in Table 13.

\subsubsection{Weld Cracking}

The claim is made that cracking is rare during the normal fabrication of these Ni-Cr-Mo alloys. ${ }^{25}$ Fabrication cracking can include hot cracking, stress cracking, and cracking related to heat treatment. Because of the complex and transient temperaturedistributions developed during fusion welding, it is inevitable that stresses are created. These stresses, together with strainintolerant microstructures that are temporarily present during solidification, and improperly shaped weld deposits, such as concave and tear-drop shapes, can lead to hot cracking. Hot cracking is generally confined to the fusion zone, but occasionally it can occur in the heat-affected zone. Excessive welding current with constrained welds can lead to hot cracking. An understanding of hot 
cracking in terms of the solidification microstructures, the corresponding segregation, and the intermetallics formed in the fusion zone was presented by Cieslak et al.19,21 Hot-cracking tests were performed on autogenous gas-tungsten-arc welds of Alloys C4, C-22, and C-276, 21 as well as of Inconel Alloys 625 and 718.19 Alloy $\mathrm{C}-4$ showed the least sensitivity to hot cracking followed by Alloys C-22 and C-276 in that order, but, with little difference between the latter two alloys. Terminal molybdenum-rich phases were associated with the cracks in Alloys $\mathrm{C}-22$ and $\mathrm{C}-276$ and nickel-rich phases in Alloys 625 and 718. No terminal phases were observed for Alloy C-4, while Alloy 718 had the largest fraction of terminal solidification constituents. Alloy C-4 was also reported as having a better resistance to hot cracking than Alloy 59.16 The dominant intermetallic phases in naturally-cooled weld-metals of Alloys C-22, C-276, and 625 are Mo-rich $\sigma$, Mo-rich P, and Nb-rich Laves structures, respectively. Alloy $\mathrm{C}-4$ did not contain any intermetallics.

\subsubsection{Weld Filler Metal}

The selection of welding filler material is a critical issue in the design of a corrosion-resistant weldment. In a review article on $\mathrm{Ni}$ Cr-Mo welding consumables, Stephenson points out some of the problems encountered in the solidification of the weld metal. 28 Alloy depletion and dendritic/coring segregation ${ }^{\mathrm{h}}$ are two of the common microstructural occurrences that take place in the fusion zone. The degree of segregation (with reference to compositional variation) is decreased with an increase in heat input as observed with Alloy 625. However, the fraction of the interdendritic phase increased and the dendritic microstructure became coarser. The coarser structure, associated with the higher heat inputs were found to become more susceptible to corrosion. In using overalloyed filler

\footnotetext{
h In the solidification of an alloy, the composition of the solid freezing out from the liquid is continuously changing, at first being rich in those elements that raise the freezing point of the liquid, then becoming more and more enriched with those elements that lower the freezing point of the liquid as solidification continues. Therefore, composition gradients (segregation) develop as the molten alloy solidifies. Generally, the solidification occurs preferentially along specific crystallographic directions producing a christmas-tree-like (dendritic) pattern, which is revealed on etching due to the compositional gradients within the individual dendritic branches. The regions between the branches consists of the final liquid to solidify. The terms "coring" and "dendritic" are used interchangeably with the former term generally used where the segregation has a cored-like appearance.
} 
metals ${ }^{i}$, high weld-heat inputs can result in unmixed fused parent metal at the fusion boundaries. If the unmixed region is sufficiently segregated, it may become corrosion-prone. Low weld-heat inputs and low interpass temperatures will diminish these tendancies.

The problems related to segregation can partially be compensated for by the use of an overalloyed filler metal. Based on the Haynes International "Suggested Filler Metal Selection Guide," however, Alloy C-22 filler weld metal (AWS Number ERNiCrMo-10) is suggested for use in the welding of Alloy C-22. Either weld filler metal of Alloy C-22 or C-4 (AWS Number ERNiCrMo-7) is suggested for the joining of Alloy C-4 components. 25 The corresponding AWS Numbers for the shielded metal arc welding electrodes are ENiCrMo10 and EniCrMo-7, respectively. Haynes International states that Alloy $\mathrm{C}-22$ is the best alloy to use as a universal weld filler metal to resist corrosion of weldments[II]

Garner evaluated the relative effect of chromium content on the corrosion resistance of welded and unwelded alloys by investigating the influence of microstructural changes caused by autogenous (without filler metal) welding on the critical pitting temperature and critical pitting potential in $10 \% \mathrm{FeCl}_{3}$ at a $\mathrm{pH}$ of about 1.0.29 Studies were performed on $316 \mathrm{~L}$ and $317 \mathrm{~L}$ stainless steels with the former steel modified with various molybdenum contents up to about 5\% Mo. Both critical values were lower for the welded areas than for the unwelded areas, with the differences between the two regions increasing with an increase in the molybdenum content. As expected, both of the critical values increased with an increase in molybdenum, which supports the beneficial role of increased molybdenum in suppressing localized corrosion.

\subsubsection{Comparison of Weld Metal and Base Metal Mechanical Properties}

Differences in tensile properties between the as-welded condition and the base metal for Alloys $\mathrm{C}-4$ and $\mathrm{C}-22$ are shown in Table 13.23,24 Alloy G-3, which can be considered to be within the family of corrosion-resistant $\mathrm{Ni}-\mathrm{Cr}-\mathrm{Mo}$ alloys, is included in the table. ${ }^{30}$ The tensile strength is virtually unaffected by the welding, whereas there

i Overalloyed refers to enrichment in the filler metal of one or more of the critical alloying elements in concentrations greater than contained in the base metal. 
is a significant increase in the yield strength and decrease in the elongation. The weldment samples had their tensile axis transverse to the welds. The all-weld filler metals give still higher as-welded yield strengths and slight increases in tensile strength compared to the values of the corresponding wrought metals, depending upon the welding method used. For example, Alloy C-22 and G-3 filler metals gave yield strengths ranging from $496 \mathrm{MPa}$ to $524 \mathrm{Mla}$ and $441 \mathrm{MPa}$ to $469 \mathrm{MPa}$, respectively. The elongations of the filler metals generally fell below the values for the base-metal specimens. ${ }^{23,30}$

\section{Comments on the Corrosion Resistance of Candidate Superaustenitic Stainless Alloys}

\subsection{Alloy G-3 (INCO Alloy G-3)}

Alloy G-3 was developed as a substitute for Alloy G. It was first produced by Cabot Corporation (now Haynes International, Inc.) and was known as Hastelloy Alloy G-3. Its production was subsequently discontinued, being replaced by the more corrosion-resistant and costlier Alloy G-30. The alloy was then reintroduced by INCO Alloys International as INCO Alloy G-3. The information presented here on Alloy G-3 is based largely on bulletins published by both organizations. 30,31

Alloy G-3 (Table 2) is similar in composition to Alloy $G$ with the exception of changes in the concentration of two elements. The molybdenum content was increased from a range of 5.50 to $7.50 \%$ to 6.0 to $8.0 \%$, while the maximum allowable carbon content was decreased from 0.05 to $0.015 \%$. These modifications were made to improve the alloy's resistance to localized corrosion and to decrease the susceptibility of the alloy to sensitzation, making it more ammenable to the use of weldments in corrosive environments. The molybdenum provides improved resistance to pitting and crevice corrosion, especially in oxidizing media, while the presence of copper ( 1.25 to $2.5 \%$ ), as well as the high nickel content, enhances the corrosion resistance in reducing media. The high nickel content also provides the alloy with exceptional resistance to stress-corrosion cracking in chloride-containing environments. The extra low carbon content minimizes the susceptibility to intergranular corrosion that can result from exposure to elevated temperatures.

Alloy G-3 will withstand the corrosive effects of both oxidizing and reducing media, and can handle both acid and alkaline solutions. It 
has excellent resistance to mixed acids, contaminated nitric acid, and flue gases. It has outstanding resistance to hot sulfuric and phosphoric acids. The alloy is resistant to stress-corrosion cracking based on U-bend tests made in boiling $\left(155^{\circ} \mathrm{C}\right) \mathrm{MgCl}_{2} \cdot 6 \mathrm{H}_{2} \mathrm{O}$ solution (ASTM G-30 and G-36) .

The decreased susceptibility to various forms of localized corrosion obtained by lowering the carbon content is illustrated in Figure 2, in which the test results of Alloys G and G-3 are compared. ${ }^{31}$ Both alloys were exposed to testing according to ASTM G-28, Method A. The significance of the results is that Alloy G-3 is expected to be significantly more corrosion resistant in the heat-affected zone than would be Alloy G.

The resistance to localized corrosion of Alloy G-3 compared to other corrosion-resistant alloys, as inferred by the relative pitting and crevice-corrosion temperatures, can be deduced from Table 14.30 These two temperatures for Alloy G-3 are considerably higher than the corresponding temperatures for Alloy 825. Tests were performed in an acidic ( $\mathrm{pH} 2)$, oxidizing $\mathrm{NaCl}-\mathrm{HCl}$ solution $(4 \% \mathrm{NaCl}+$ $\left.0.1 \% \mathrm{Fe}_{2}\left(\mathrm{SO}_{4}\right)_{3}+0.01 \mathrm{M} \mathrm{HCl}\right)$.

\subsection{Alloy 825 (Incoloy 825)}

According to Inco Alloys International,32 Alloy 825 has a high level of corrosion resistance. In both reducing and oxidizing environments, the alloy resists general corrosion, pitting, crevice corrosion, intergranular corrosion, and stress-corrosion. It has a high resistance to cracking in chloride environments. It is highly resistant to most alkali solutions and most organic acids, and it has good resistance to general corrosion, pitting, and to crevice corrosion in sea water. It has good resistance to wet sulfur dioxide and to many sulfurous acid solutions. Alloy 825 , however, is subject to biological fouling in continuous sea-water immersion. It is not resistant to oxidizing acid chlorides such as cupric or ferric chloride, nor to wet chlorine and hypochlorite solutions except in dilute solutions. It is only moderately resistant to hydrofluric acid and to solutions of fluoride salts. The alloy is susceptible to being sensitized to intergranular corrosion if the titanium carbides are

\footnotetext{
j ASTM G-30 describes procedures for making and using U-bend samples for the evaluation of stress-corrosion cracking (SCC) in metals. ASTM G-36 describes the procedure for evaluating SCC in a boiling magnesium chloride solution.
} 
destabilized on exposure to temperatures in the range of about 650 to $760^{\circ} \mathrm{C}$, as during welding or in service. Also, exposures to temperatures above $540^{\circ} \mathrm{C}$ can result in the precipitation of embrittling phases that may significantly lower the ductility and impact strength of the alloy. 32 In reviewing the literature published on Alloy 825, Strum et al noted that the corrosion rate for this alloy did not increase as a result of welding. ${ }^{33}$ Welded samples and solution-annealed samples were exposed to a large number of different environments, but for short periods of time (4 to 168 hours).

\section{Technical Information and Fabrication Guidlines on Candidate Superaustenitic Stainless Alloys}

\subsection{Alloy G-3 (INCO Alloy G-3)}

Information on heat treatments, fabrication, and machining on Alloy G-3 appears to be limited to two brief bulletins. 30,31 The alloy is available in a wide range of wrought mill forms including rod, bar, plate, sheet, strip, and tubular products. The mill products are generally supplied in the solution-annealed condition. Solution annealing consists of heating to between 1150 and $1175^{\circ} \mathrm{C}$ and followed by either water quenching or rapidly cooling in air.

The alloy is readily fabricated by all the common methods. It can be readily both hot and cold worked. Forming operations are performed by standard procedures used for nickel alloys. The alloy is machinable using cither carbide or high-speed-steel tools. The carbide tools are recommended for high cutting speeds and heavy feeds. Tools should have positive rake angles and should be operated with continuous cutting to avoid work hardening of the workpiece surface. As with other austenitic materials, the alloy work hardens rapidly.

Alloy G-3 has good weldability and does not need any post-heat treatment for restoring corrosion resistance. The alloy can be readily welded by gas metal-arc welding (GMAW), gas tungsten-arc welding (GTAW), and shielded metal-arc welding (SMAW). INCO welding electrode G-3 and filler metal G-3 are recommended for use with SMAW and with both GMAW and GTAW, respectively Typical mechanical properties reported for welded 1/2-inch to 3/4-inch $(12.7-$ to $19.1-\mathrm{mm})$ thick plate are shown in Table 13.30 
It should be noted that although data specifically on Alloy G-3 is very limited, the information available on other nickel-base corrosion-resistant alloys should also be applicable here. For example, the operations, guidelines, and precautions presented in the discussions on Alloy 825 would be applicable to Alloy G-3.

\subsection{Alloy 825}

Much of the technical and fabrication data given in the following is based on information provided in the Inco Alloys International ${ }^{34,35}$ and Nickel Development Institute 26 bulletins. Whereas the technical and fabrication information made available by Haynes International was generally applicable to all their corrosion-resistant $\mathrm{Ni}-\mathrm{Cr}-\mathrm{Mo}$ alloys, similar information presented by Inco Alloys International covered a wide range of nickel-based alloys, in many cases having quite different characteristics. Therefore, at times the information was questionable as to its relevance to Alloy 825 when extracting information from the general discussions on their alloys. Such questionable information is not included here. The precautions and guidelines specified for the fabrication and especially for the cleaning and heating of the corrosion-resistant Hastelloys would also be applicable here.

Alloy 825 has excellent fabricability and weldability and is readily machinable by conventional means. The alloy is available as rounds, flats, forging stock, pipe, tube, plate, sheet, strip, and wire. In all forms, the alloy is furnished in the solution heat-treated condition.

\subsubsection{Heat Treatment}

Solution annealing (stabilization) of Alloy 825 is performed in the temperature range of 927 to $982^{\circ} \mathrm{C}$ with the optimum stabilization being obtained at about $940^{\circ} \mathrm{C}$. The optimum combination of softness and fine-grain structure as required for deep-drawing operations, without any loss in corrosion resistance, is obtained on heating to the upper limit of this temperature range. Fast cooling, ranging from rapid air cooling up to a water quench depending on section size, is necessary to prevent sensitization to corrosion. Unstabilized material can become sensitized on exposure to the temperature range between 650 and $760^{\circ} \mathrm{C}$. Exposures to temperatures above $540^{\circ} \mathrm{C}$ can result in the formation of brittle phases that may significantly lower ductility and impact strength. 
Depending on the initial microstructure, degree of cold work, and the annealing time, recrystallization can be achieved above about $650^{\circ} \mathrm{C}$. For example, $20 \%$ cold reduction of fine-grain sheet requires about 15 minutes at $800^{\circ} \mathrm{C}$ for complete recrystallization. Above $1010^{\circ} \mathrm{C}$, rapid grain growth occurs due to the dissolution of finely dispersed carbides. For work-hardened, carbide-stabilized nickel alloys, stress relief is usually done in the range of 480 to $870^{\circ} \mathrm{C}$. Stress equalization is usually performed in the range of 260 to $370^{\circ} \mathrm{C}$.

The metal must be thoroughly cleaned of all foreign substances, such as lubricants, storage and shop soil, paints, crayon markings, pickling liquids, and slag, prior to heating. Low-melting elements that embrittle the alloy are present in many of these substances. The workpiece should be protected during heating. Contact with any refractory materials (hearth or surrounding dust) must be avoided. Low-sulfur fuels must be used if heating fuels, rather than electrical heating, are used. The atmosphere must be sulfur-free and slightly reducing to neutral with care to avoid any intrusion of oxidizing conditions. A reducing atmosphere containing at least 2\% carbon monoxide is recommended. Nickel alloys form an adherent oxide film on air cooling which is difficult to remove. Therefore, the alloy should be cooled under a protective atmosphere or, if at faster cooling rates, in a reducing quench bath. 35

\subsubsection{Hot Working/Forming}

The hot-working range for Alloy 825 is specified as $1175^{\circ} \mathrm{C}$ down to $870^{\circ} \mathrm{C}$. Heavy reductions should be done above $1010^{\circ} \mathrm{C}$; light reductions between 1010 and $870^{\circ} \mathrm{C}$ and between 650 and $540^{\circ} \mathrm{C}$ The range between 870 and $650^{\circ} \mathrm{C}$ is to be avoided. To ensure maximum corrosion resistance, some reduction must be made in the range of 980 to $870^{\circ} \mathrm{C}$ during the final hot-working stagc. Heavy sections may become sensitized during cooling from the hot-working temperature and be subject to intergranular corrosion. Thus, care must be taken to cool at a rate equal to or faster than air cooling, depending on section size. If the material is to be welded or subjected to further thermal treatment and subsequently exposed to an environment that may cause intergranular corrosion, the hot-working operation should be followed by a stabilizing anneal. The original cast structure must be completely removed during the breakdown stage of the ingot. 
The Inconels and Incoloys require considerably higher hot-forming pressures (about double) compared to the pressures needed for austenitic stainless steels, as well as requiring more powerful equipment. Cabon-steel forging dies are adequate for production of small parts. Alloy-steel dies are recommended for large or intricate parts or for long runs. Only sulfur-free lubricants such as colloidal graphite, which are used to facilitate removal of the workpiece from the forging die, are to be used. To avoid chilling of the workpiece, tools and dies should be preheated to about $260^{\circ} \mathrm{C}$. Excessively heavy forging should be avoided in order to prevent adiabatic ${ }^{k}$ overheating into the range of rapid grain growth.

\subsubsection{Cold Working/Forming}

In the annealed condition, Alloy 825 has excellent ductility and is adaptable to virtually all methods of cold fabrication. The high work-hardening characteristics (similar to austenitic stainless steels) combined with high ductility provides for a wide working range between the yield and ultimate values (Table 3) before cracking or tearing occurs.

To minimize the tendency towards galling, heavy-duty lubricants are recommended for most cold-forming operations. Unsaturated or polar fatty-acids oils and vegetable oils are suggested for less severe operations and, even when diluted, they are good lubricants for moderate deep-drawing operations. Ordinary petroleum greases and phosphates are normally not used in forming the high nickel alloys. Light-bodied mineral oils and water-based lubricants can be used only in light forming operations.

For severe deformations; sulfur- or chlorine-bearing lubricants are recommended. The sulfur and chlorine form compounds on the abraided deforming surfaces that increase the effectivness of the lubricant. The compounds only form if sufficient heat is generated, as in heavy deformations or high-speed forming. These lubricants must not be used if the sulfur or chlorine cannot be completely removed after forming. Sulfur can embrittle the metal on exposure to elevated temperatures. Chlorine will cause the metal to become susceptible to pitting. Metallic coatings can be used as lubricants in

" The term "adiabatic heating" refers to heat generated during the deformation of the workpiece which is retained in the workpiece, and raises its temperature. 
severe cold-forning operations, but only when they can be properly removed after forming.

The sulfur- and chlorine-bearing lubricants should not be used in spinning, as this operation tends to burnish the lubricant into the metal surface. Similarly, molybdenum disulfide generally should not be used. Solid lubricants such as bar soap and beeswax are readily applied in spinning operations by holding the lubricant against the rotating workpiece.

Pigmented lubricants containing low melting compounds such as lead carbonate (white lead), zinc oxide, or other metallic compounds, must be avoided, as these compounds can cause embrittlement if not removed before heat treatment.

The high strain-rate sensitivity and frictional characteristics of the alloy dictate that all cold-forming operations, exclusive of highenergy-rate operations, be performed at relatively low speeds. Because of their galling tendencies on high nickel-bearing alloys, water-hardening tool steels should not be used in the cold forming operations. Oil-hardening steels offer some improvement. The highly alloyed air-hardening tool steels perform well. Carbide dies provide the maximum length of service, but they cannot withstand the high tensile and impact loads encountered in the forming of large parts. Soft die materials such as aluminum bronze will give superior surface finishes, but have a short service life. Nonmetallic die materials such as hardwood, synthetic rubbers, and plastics work well in light forming operations.

The nickel-based alloys can be drawn into any shape that is feasible with deep-drawing steel. For simple shapes, dies and tools designed for steel or copper-based alloys can be used. For complex shapes minor dimentional modifications of the dies may have to be made. Because of their higher mechanical properties compared to deepdrawing steel, less wall thinning occurs requiring an increase in die clearance. The rapid work hardening will also generally require an increase in the punch and die-ring radii.

During the various mechanical operations, either hot or cold, small particles of iron may become entrapped in the workpiece. The particles may become so embedded in the surface that they cannot be removed by the methods normally used to remove other foreign matter. Since the iron particles can become sites for localized 
corrosion it is imperative that these particles be removed. Several different alternative chemical tests are suggested in order to detect the presence of any entrapped iron, as well as methods for its removal. 35 For example, applying a solution of $1 \% \mathrm{NaCl}$ for from 12 to 24 hours will develop rust spots identifying the presnce of the particles. The iron can then be removed by applying a cold solution of $\mathrm{HCl}$ and $\mathrm{FeCl}_{3}$, and followed by rinsing The detection, removal and cleaning processes are repeated until all the particles are removed.

\subsubsection{Machining and Grinding}

The discussion on machining is based primarily on information given in the bulletin on machining of nickel-based alloys. ${ }^{36}$ The alloys are separated into several different groupings with Alloy 825 in Group C, the group that contains most of the Incoloy alloys. Alloy 825 normally has optimum machining characteristics in the annealed condition, 32 although, in general, the alloys in Group $\mathrm{C}$ are best machined in the cold-drawn or cold-drawn-and-stress-relieved conditions. It can readily be machined by any of the standard methods used for iron-based alloys. Because of the tendency to work harden rapidly, it is best to use heavy equipment, with cutting tools large and heavy enough to withstand the load and to quickly dissipate the generated heat. To minimize the effect of work hardening, use sharp cutting tools with positive rake angles, which cut rather than push the metal. The correct side- and end-relief angles must be used to provide the proper clearance between the tool flank and the workpiece. Feed rates and cut depths must be sufficient to prevent burnishing or glazing. To minimize distortion and to maxmize dimentional stability, it is best to rough out the material slightly oversize, stress relieve, and finish to size.

Virtually any lubricant or coolant can be used, and in some cases none at all. Sulfurized mineral oils can be used with some precautions. Sulfur improves the lubricity, antiweld properties, and chip-forming action. If the oil and workpiece become too hot, a brown sulfur stain will appear on the workpiece. The stain must be removed prior to any heat treatment as the sulfur will cause intergranular attack. Exposure in the cleaning solution should be limited as prolonged exposures in some of the acid-cleaning solutions can result in intergranular corrosion. The sulfurized oils should also be avoided for high-spced opcrations using ccmented carbide tooling. At the high temperatures that develop, the sulfur can embrittle the 
cobalt or nickel matrix of the carbide tools. Nevertheless, cemented carbide tools are recommended for most operations involving uninterrupted cuts. Water-based coolants are preferred for high speed operations. For slow operations, such as drilling or boring, heavy lubricants with rich mixtures of chemical coolants are recommended. For simple turning operations, a spray-mist coolant is adequate. Some chemical activity is desired between the coolant and workpiece surface for most machining operations, and this is obtained through proprietary compounds added to the coolant by the manufacturer.

It is important that steady feed rates are used in drilling. If the drill is allowed to dwell, it will cause excessive work hardening of the metal at the bottom of the hole. This will make it more difficult to resume drilling and may result in failure of the drill. Heavy-duty high-speed drills with a heavy web are recommended. Cutting action with drills larger than $3 / 4$ inch $(19 \mathrm{~mm})$ in diameter can be improved by grinding several small grooves through the lip and extending back along the lip clearance. Gun drills are used for deep holes up to 2.5 inches $(63.5 \mathrm{~mm})$ diameter, with highly sulfurized-oil coolant. If reaming is required, the speed should be $2 / 3$ of the speed used for drilling the same material, but not so high as to cause chatter. Lack of rigidity, misalignment, and dull tools can also contribute to chatter.

In cold cutting heavy sections, it is best to use circular saws with insert teeth. An example is given for a 1.1 meter-diameter blade with 56 inserted high-speed teeth, which are ground and set in a specific manner. ${ }^{36}$ The cutting is done at a saw speed of 7.6 meters per minute with a feed rate of $8.5 \mathrm{~mm}$ per minute. Sulfurized oil is used as the cutting fluid, with the usual precaution of its complete removal prior to subsequent heat treatment. Cutting-off operations can be done using a hand or power hacksaw, with high-speed-steel blades and the power hacksaw operating at 60 strokes per minute. Band sawing can also be used; high-speed-steel saws with flexible backs and as-tempered by the manufacturer are recommended. The workpiece for both band saws and hacksaws should be flooded with cutting fluid. In abrasive cutting, dry cutting can be used for sections up to $25.4 \mathrm{~mm}$ thick. Aluminum oxide resinoid-bonded wheels are recommended. Wet cutting is preferred for thicknesses over $25.4 \mathrm{~mm}$. Here, the use of water containing a rust inhibitor is satisfactory. Surface speeds should be between $1,524 \mathrm{~mm}$ and 
$1676 \mathrm{~mm}$ per minute with a feed rate being the maximum permitted by the machine.

Grinding methods used for the high nickel alloys are similar to those used for steels. When only a small amount of metal is to be removed, the finishing operation may be done using rough and final fine grinds. Allowing the part to cool to ambient temperature after rough grinds allows redistribution of internal stresses, and any residual distortions can be corrected in the final grinding operations. Wet grinding is preferred, and the use of aluminum oxide wheels is recommended. Grinding pressure should be great enough to cause slight wheel breakdown.

Surface grinding is best performed with coarse (40-60) grit. Low wheel contact and low pressure will help to prevent distortion. Reciprocating tables are preferred, as they have less wheel contact, generate less heat, and cause less distortion than do rotary tables.

Crush-form grinding (using shaped wheels) is best done with vitrified-bonded, medium-grade aluminum oxide wheels having medium-to-open structures. A high-grade grinding oil should be used with continuous filtering throughout all operations.

\subsubsection{Welding}

Much of the material in this section is based on information presented in references 26,34 , and 37 . Although different techniques than those used for other materials may be required, all conventional processes can be used for welding Alloy 825. The welding procedures are similar to those used for austenitic stainless steels. The thermal expansion characteristics of Alloy 825 are closer to carbon steels than to the stainless steels. This results in less distortion and lower residual stress in the superaustenitic stainless alloys than in the conventional stainless steels when using comparable welding methods. Preheating is usually not required except for the prevention of condensation on cold metal. Post-weld heating is also generally not required. Surfaces must be cleaned of all foreign matter before welding. Common contaminating elements and their possible sources are listed in Table 12 .

The molten metal of the superaustenitic stainless alloys is considerably less fluid than that of carbon steels and somewhat less fluid than that of the conventional stainless steels. Weld penetration 
is therefore more sluggish. Unlike carbon-steel weld metal, nickelalloy weld metal does not spread. To spread the metal, it is often necessary to weave the electrode slightly, the amount of weave being dependent on the joint design and electrode type. The weave should not be wider than three times the core-wire diameter. Full penetration is important to avoid potential sites for crevice corrosion and possible loss of strength in butt and vee joints. To compensate for the lower fluidity, nickel-alloy joints have a wider bevel, narrower root face, and wider root opening than is used for carbon steels. The joint opening must be sufficient to permit the torch, electrode, or filler metal to extend to the bottom of the joint.

Choice of welding process will influence the weld-joint dimensions. For example, a spray-arc gas-metal-arc weld has a deeper penetration weld bead than other arc-welding processes so that thicker root faces may be used. Unless both sides of a joint can be welded, a backup material should be used wherever possible in welding plate or sheet. This will decrease the chance of crevices, voids, and excessive oxidation. The use of a backing protective gas is mandatory. The backing material should not be fused to the weld metal and should be removed after the welding. Copper is recommended as a backing material. Because of its high thermal conductivity and chilling effect, the copper will not be melted. Joints not held in fixtures must be tack-welded to maintain a uniform gap and alignment along the entire length with the first two beads made at the two extremities of a joint. The shape of the tack (or spot) bead should not cause a defect in the final weld. The bead shape is best controlled by using the gas tungsten-are weld process. The beads should then be wire brushed and, if necessary, contour ground; also, any cracks or craters should be ground out. Where either welding on both sides or backing plates cannot be used, the gas tungsten-arc weld process, which provides the best underbead contour, should be used. For material over $9.5 \mathrm{~mm}$ thick, a double-U or $\mathrm{V}$ joint is preferred. To resist axial stresses, butt joints are preferred over lap or corner joints.

The choice of the welding process should be based on 1) thickness of metal to be joined, 2) design of the component, 3) design of the joint, 4) position of the joint, 5) need for fixtures or jigs, 6) special shop or field conditions, and 7) type of service exposure.

Shielded metal-arc, gas tungsten-arc, gas metal-arc and submergedarc welding processes are the main joining methods in use for the superaustenitic stainless alloys. Plasma-arc, electron-beam, and 
laser welding process are being used with increasing frequency. Although resistance welding is not mentioned in the Inco bulletin on welding, ${ }^{34}$ in the Alloy Digests on the Carlson and Allegheny Ludlum alloys (Alloy C825 and AL 825 Alloy) equivalent to the Inco Alloy 825 , resistance welding is also indicated as one of the common methods used for these alloys.

The shielded metal-arc welding process is used when the shapes and quantities do not justify the use of automatic welding. The fillerwire electrode is covered with a flux that decomposes and forms into a gaseous envelope that protects the molten metal from the environment. The same techniques for arc starting and stopping used for low-hydrogen carbon-steel electrodes are applicable for welding nickel alloys. The arc should be struck at a point in the joint that will be remelted. The arc should not be abruptly extinguished, as this is likely to cause a large weld crater. For control of the weld puddle, it is necessary to maintain a short arc length. The correct amount of weave and electrode manipulation depend upon the joint design, welding position and electrode type. This should be determined with practice runs. Under correct welding conditions, excessive spatter should not occur. If excessive spatter occurs, it may be caused by one of the following factors: 1) excessive arc length, 2) excessive current, 3) incorrect polarity, 4) excessive moisture in the electrode coating, or 5) magnetic arc blow. The problem can be readily corrected, with the corrective measures the same as those used for steels.

In the gas metal-arc welding process, the arc is established between a consumable, bare-wire electrode and the workpiece. This process has several advantages over the shielded metal-arc and gas tungsten-arc processes, namely. 1) faster welding speeds, 2) no slag, minimizing post-weld cleanup, 3) ease of automation, and 4) good transfer of elements across the arc. It has, however, more weldparameters to control, making it more complex and more expensive than the other two processes. The type of metal transfer used in the gas metal-arc welding process has a profound influence on the process characteristics, and guidelines can differ for the different arc-transfer modes. The three most frequently used modes for welding the nickel-based alloys are the spray-arc, the shortcircuiting-arc, and the pulsed-arc modes.

The spray-arc mode is characterized by high deposit rates and high heat inputs. It is generally limited to the flat position. The short- 
circuiting-arc mode provides a low heat input and minimizes distortion in thin gauge materials. It has limitations when used on multiple-pass, thick joints. The process can be prone to lack-offusion defects. The weld beads tend to be convex, which would necessitate grinding each bead to assure full penetration to the side walls. The process is most useful for single-pass welding. The pulsed-arc mode is considered as an excellent compromise between the other two modes.

The shielding gas for all three modes normally contains at least 97.5\% inert gas: argon, helium, or a mixture of the two. Some mixtures may also contain up to $2.5 \% \mathrm{CO}_{2}$ which may present additional work in the welding of chromium-rich stabilized alloys such as Alloy 825. The oxides of aluminum, titanium, and chromium that form are very refractory and tightly adherent, and must be removed by careful grinding between passes.

The gas tungsten-arc welding process is widely used and is well suited for welding nickel alloys. Argon is the preferable protective gas, with helium or mixtures of the two gases also being acceptable. When extinguishing the arc, the size of the weld pool should be gradually decreased, otherwise crater cracking is likely to occur as the weld solidifies. Proper arc-stopping practice is especially important in the root pass of welds that are welded only from one side. Ample shielding is recommended to protect both the weld puddle and the root side. The filler metal should be kept within the inert-gas envelope during welding. In some welds, inadequate filler can result in a concave bead that has a tendency for centerline cracking. Uneven melting of filler metal along with fast solidification rates can cause segregated spots of melted base metal and filler metal, respectively. Experience has shown that at least half of the fusion zone should consist of melted and re-solidified welding consumables.

Although the submerged-arc welding process is not recommended for use with the Ni-Cr-Mo alloys (for example, Alloys C-4 and C-22), this process is useful for joining thick sections of other nickel-based alloys. Inconel filler metal 625 , which is one of the filler metals recommended for use with Alloy 825, is used with the submergedarc process. Reference to the use of this process specifically for Alloy 825 could not be found. Nevertheless, because of its many advantages and its use with other nickel alloys such as Inconel 625 and Monel 400, as well as its possible use with Alloy 825, the process 
is discussed here. Submerged-arc welding provides high deposition rates, thick beads, stable arc, and smooth as-welded surfaces. It is important to use the proper type and amount of flux. Only enough flux to prevent arc brcakthrough should be used. Excessive flux can cause a deformed bead surface. Poor weld contour, flux entrapment, weld cracking, and inclusions can result when the wrong flux is used. Fluxes should be stored in a dry area, as they are subject to moisture pickup. Absorbed moisture can be eliminated by baking at about $400^{\circ} \mathrm{C}$, followed by holding at 120 to $150^{\circ} \mathrm{C}$ until being ready to weld. The recommended filler metals are the same as the filler metals or electrode wires used for gas metal-arc and gas tungsten-arc welding. Slag entrapment is avoided with proper joint design and proper placement of the beads. Slag (solidified residue from the flux) must be removed from the weld bead, which may be inconvenient in multiple-pass welding. Beads should be placed so as to provide an open or reasonably wide root area for the next bead, with the beads having a slightly convex contour. The chemical composition remains virtually constant through the deposited metal with no accumulation of flux components. In addition to protecting the molten metal from atmospheric contaminants and providing arc stability, flux components contribute important additions to the weld metal.

Guidelines and precautions in the welding of Alloy 825 are:

- Remove all foreign material from surface, including any embedded particles, slag, and surfacc oxides, cspccially in the weld-zone areas.

- Remove all oxides and dross from thermal cutting before welding, as the oxides of chromium and titanium, having high melting points, will not be fused by the weld metal and will be entrapped as defects.

- Remove moisture from metal surface, as moisture can cause porosity in the weld metal. If the base metal is cold (below $3^{\circ} \mathrm{C}$ ), preheat the area surrounding the weld zone to about $20^{\circ} \mathrm{C}$ to prevent condensation.

- Avoid flat or convex beads. Make all beads with slightly convex contours.

- Design the bottoms and attachments of containers for complete and free drainage to avoid crevice corrosion.

- Use backing material on the back side of a weld, where possible.

- Use tack welds for maintaining alignment when joints are not held in fixtures 
- Design and space joints to facilitate full penetration of weld metal.

- Use gas tungsten-arc weld process for root pass when joints cannot be welded from both sides.

- Avoid uneven melting of filler metal.

\subsubsection{Weld-Filler Metals and Electrodes}

Incoloy welding electrodes 112 (AWS A.5. 11 ENiCrMo-3), 122(AWS A 5.11 ENiCrMo-10), and 135 (DIN 1736 EL-NiCr28Mo) are recommended for the shielded metal-arc welding process. 38 Electrode 112 has relatively high strength (Table 15$)^{38}$ with exceptional corrosion resistance, including resistance to pitting and crevice corrosion. Electrode 122 is designed to offer protęction against preferential weld-metal corrosion when used to welding molybdenum-containing nickel alloys. Electrode 135 has good resistance to pitting and general corrosion, especially in reducing environments such as phosphoric and sulfuric acids. As seen from Table 16,38 electrode 122 has a much higher molybdenum content than electrode 135 , while electrode 112 has a molybdenum content intermediate between the two. Electrodes 112 and 122 have about the same chromium content, which is significantly lower than that contained in electrode 135 (21 versus 28\%). Other significant differences are in the carbon content and in the presence or absence of carbide stabilizers. The three electrodes can be operated in all welding positions.

Inconel filler metals 65 (AWS A5. 14 ERNiFeCr-1) 622 (AWS A 5.14 ERNiCrMo-10), and 625 (AWS A5. 14 ERNiCrMo-3) are recommended for the gas metal-arc and gas tungsten-arc welding processes. 38 Filler metal 65 is considered as highly corrosion resistant, especially in reducing environments. Filler metal 122 provides good resistance to pitting and crevice corrosion and offers protection against preferential weld-metal corrosion when used for joining molybdenum-containing nickel alloys. It is useful for joining many dissimilar metals. Filler metal 625 is considered as having exceptional corrosion resistance, including resistance to localized attack such as pitting and crevice corrosion. The main differences in composition are in the molybdenum content and in the carbide stabilizers (Table 16). 
For Alloy 825, in applications requiring the highest resistance to pitting, use Inconel welding electrode 112 and Inconel filler metal 625 , and use a stabilizing anneal following the welding. In general, the use of highly alloyed fillers to match the corrosion resistance of the base metal is recommended, and pre- or post-weld heating is usually required. The use of a maximum interpass temperature of $150^{\circ} \mathrm{C}$, with an arc length as short as possible, is also recommended.

\subsubsection{Additional Comments on Welding}

A note of precaution is made with respect to the welding of thick sections. In reviewing the bulletins containing information on Alloy 825 and published by Inco Alloys International,32,34,35,38 data on properties of weldments were given without any reference to thickness. In a private communication reported by Strum et al, Lingenfelter noted that gas metal-arc and gas tungsten-arc weldments of Alloy 825 using filler metal 65 or electrode 135 exhibited microfissuring. 33 This was with reference to $25.4-\mathrm{mm}$ thick butt joints. He further noted that such austenitic alloys will frequently have adequate cracking resistance to produce crack-free welds up to $6.4 \mathrm{~mm}$ or perhaps $12.7 \mathrm{~mm}$ thick. The problem with the greater thicknesses arises due to the higher levels of restraint imposed by the added thickness. The authors note that there is very little information available on hot cracking of Alloy 825. They suggest the possible use of friction welding since this does not involve melting; the hot cracking occurs during the solidification process.

\section{Titanium}

\subsection{Comments on Corrosion}

Commercially pure titanium, such as Ti-Grade 2, has excellent corrosion resistance in most aqueous salt solutions, including chlorides, hypochlorites, sulfides, sulfates, nitrates, and phosphates. The metal, however, is not especially resistant to nonoxidizing media, such as $\mathrm{HCl}$ and $\mathrm{H}_{2} \mathrm{SO}_{4}$. It has limited resistance to hot concentrated solutions of $\mathrm{AlCl}_{3}, \mathrm{CaCl}_{2}, \mathrm{MgCl}_{2}$, and $\mathrm{ZnCl}_{2}$. On hydrolizing, these salts form non-oxidizing acid solutions, and tend to pit the metal at high temperatures and high salt concentrations. Bomberger stated that unalloyed titanium should not be used in uninhibited acid-chloride solutions at high temperatures, and that 
crevices should be avoided even in hot neutral chloride solutions. 39 He further stated that only corrosion-resistant titanium alloys should be used whenever crevices cannot be avoided or when used in uninhibited nonoxidizing acid solutions.

A small addition of a noble metal (Pd, Pt, or $\mathrm{Ru}$ ) to Ti-Grade 2 greatly improves its corrosion resistance in non-oxidizing media without detracting from its corrosion resistance in oxidizing media. The addition of the noble metal also significantly increases the resistance to localized corrosion. The noble metal deposits on and enriches the surface of the alloy as it starts to corrode, reducing the hydrogen-evolution overvoltage. An example of the effect of small additions of a noble metal on reducing the corrosion resistance is illustrated in Figure $3^{40}$ for exposure to boiling $\mathrm{HCl}$ solutions. The enhanced resistance imparted by the noble metal led to the development of several new alloys containing small amounts of either palladium or platinum, of which Ti-Grade $7(0.12$ to $0.25 \%$ $\mathrm{Pd}$ ) became the most popular. However, the use of this alloy is limited because of its high cost.

To obtain a cheaper alloy that would be acceptable as a substitute for Grade 7 in most applications, Ti-Grade 12 (Ti-0.8Ni-0.3Mo) was developed (Table 2). It has similar, although somewhat inferior, corrosion properties to those of Grade 7.41 A number of different mechanisms have been proposed to explain the passivation role of nickel, which is present in the passive film. 41 Most recently, some new alloys were developed containing additions of palladium. 40,42 One of these is Ti-Grade 16 , which consists essentially of $0.05 \% \mathrm{Pd}$ added to Ti-Grade 7 (Table 2). The corrosion resistance of Grade 16 is close to that of Grade 7, but with a significant reduction in cost Table 17.40 .

According to Schutz et al, the addition of nickel to unalloyed titanium improves its resistance to general corrosion in hot reducing acids as well as to chloride-crevice corrosion. ${ }^{43}$ The addition of molybdenum enhances resistance to general corrosion in hot reducing-acid media, but with less potency than that of nickel. Limitations imposed by weldability, ductility and formability, together with various types of corrosion studies, led to the composition for Ti-Grade 12. The immunity of the alloy to crevice attack and pitting in near-neutral saturated brine up to $232^{\circ} \mathrm{C}$ demonstrated its improvement over the commercially pure (C.P.) grades of titanium. It is clear that, although 
the additions of nickel and molybdenum to titanium greatly improved the performance of titanium in many corrosive environments, in the more severe environments, the corrosion resistance of Ti-Grade 12 does not meet the corrosion resistance of either Ti-Grade 16 or 7 .

The relative resistance to crevice corrosion of Grade 12 (containing $\mathrm{Ni}$ and Mo) versus that of Grades 7 and 16 (both containing Pd) in naturally-aerated, saturated $\mathrm{NaCl}$ brine over a range of temperature and $\mathrm{pH}$ values is shown in Figure 4.40 The authors lump together the alloys containing the noble metals ( $\mathrm{Pd}$ and $\mathrm{Ru}$ ), irrespective of the amounts of these clements present, indicating the commonality in the superior behavior of these alloys relative to that of the C.P. titanium grades (Ti-Grades 1 and 2) and Ti-Grade 12. The relative merits of Ti-grades 7,12 , and 16 , reported by RMI Titanium Company, are shown in Table 18.44

Gdowski and Ahluwalia noted that Ti-Grade 7 and the two candidate materials, Ti-Grades 12 and 16 (Table 2), are likely to be very resistant to crevice corrosion under the conditions currently expected at the Yucca Mountain repository. 45 They also state that although Grade 7 has the highest resistance to crevice corrosion, it is not a candidate material because of its relatively high cost.

To evaluate the weldability of the more corrosion-resistant titanium alloys, comparisons of corrosion rates in boiling $\mathrm{HCl}$ at several different concentrations were made between the as-received base metals, weldments, and base metals that were heated to different temperatures and air cooled (simulation of heat-affected zones). Differences in the corrosion rates between the different conditions for Grade 16 and, especially, for Grade 7 were very slight (Figure 5). ${ }^{42}$ Additional comments on the corrosion of titanium and its alloys are presented in Appendix A.

\subsection{Microstructure}

On heating, pure titanium undergoes a transformation at $885^{\circ} \mathrm{C}$ from an hexagonal close-packed crystal structure, referred to as the alpha $(\alpha)$ phase, to a body-centered cubic crystal structure, referred to as the beta $(\beta)$ phase. Alloying elements can be added to stabilize either one of these phases, forming the alpha, alpha-plus-beta, and beta series of alloys. 
Ti-Grade 12 is a mixture of $\alpha-\mathrm{Ti}, \mathrm{Ti}_{2} \mathrm{Ni}$ intermetallic phase, and $\beta-(\mathrm{Ti}-$ Mo). The microstructure consists of alpha grains with 10 to $15 \%$ of beta phase. The beta phase is located primarily along grain boundaries and at triple points (intersection of grain boundaries of three or more grains). The intermetallic compound is seen at the boundaries between the alpha and beta phases and within the beta grains. Acicular (needle-like) alpha microstructures are found primarily in welds and in the heat-affected zones. The presence of the beta phase results in a significant increase in strength over that of the all alpha-phase material (compare the strength of Ti-Grade12 with Grade 7 in Table 3).

Ti-Grade 16 is a relatively new alloy with very little available information. 45 It is an all alpha (single-phase) alloy. The microstructure is strongly dependent on the thermomechanical history of the alloy. On one extreme it can consist entirely of equiaxed alpha grains resulting from cold work and recrystallization. A sufficiently low forging temperature might also produce a recrystallized structure. On the other extreme, it can consist of various morphologies, such as acicular or Widmanstatten ${ }^{1,}$ produced directly from the transformation of the beta phase on cooling. In addition, elongated grains may be present due to unidirectional deformation of the metal.

If the beta-to-alpha transformation occurs during deformation, the alpha separating from the beta takes on an equiaxed microstructure, called "primary alpha". This is due to the alpha continuously recrystallizing and undergoing grain growth into the transforming beta phase. However, if the deformation ends before the beta transformation is completed, the remaining beta transforms to the acicular-alpha microstructure.

\subsection{Technical Information and Fabrication Guidelines on Titanium}

Titanium Ti-Grade 12 is available as sheet, strip, plate, bar, billets, forgings, welded tubing, and welding wire. It is considered to be a

\footnotetext{
${ }^{1}$ The term Widmanstatten refers here to a pattern of alpha platelets formed along specific crystallographic planes and directions of the beta phase during the final stages of transformation of beta to alpha on cooling at intermediate cooling rates. The morphology can vary from acicular (needle-like) to platelets, and if extensive it can have a basket-weave appearance.
} 
low-medium strength, alpha-titanium alloy that is readily warm or cold formed and is highly weldable. It can be reduced up to $40 \%$ by cold working. The alloy responds to conventional heat treatments such as stress relief, mill anneal, and recrystallization. The alloy is normally used in the mill-annealed condition, which is obtained by heating to between 760 and $815^{\circ} \mathrm{C}$ for from 30 to 60 minutes, followed by cooling in air. Table 19 , which is reproduced from an RMI Company data sheet, shows typical values of a number of physical and mechanical properties of Ti-Grade 12.46 Other than ASTM minimum tensile requirements (Table 3 ), mechanical properties of Ti-Grade 16 were not available. It is assumed that they would be close to those of Grade 7. One disadvantage of titanium and most of its alloys is that their strength decreases rapidly with increasing temperature.

\subsection{Heat Treatment}

Flat-rolled products (sheet, strip, and plate) of Ti-Grade 12 are generally supplied in the final mill-annealed condition, depending on product form and/or customer requirements. Heat treatments range from 540 to $815^{\circ} \mathrm{C}$, similar to those for the C.P. grades. Annealing plate or strip products in the temperature range from 730 to $815^{\circ} \mathrm{C}$ will usually yield a recrystallized microstructure. For extensivelyworked material, soaking at $700^{\circ} \mathrm{C}$ for $1 / 2$ to 2 hours is sufficient. Normally, heat treatment following fabrication is not required; however, where close machining tolerances have to be held, stress relief may be required. For sheet products of Ti-Grade 12, a stressrelief anneal is performed on heating at 540 to $650^{\circ} \mathrm{C}$ for $1 / 2$ hour and cooling at any convenient rate. With plate material, the recommended time is one hour per $25.4 \mathrm{~mm}$ of thickness. For TiGrade 7 the corresponding temperature range is 540 to $600^{\circ} \mathrm{C}$.

The furnace atmosphere should be slightly oxidizing to minimize hydrogen contamination. Inert gases are recommended only for parts containing very thin sections that require multiple heating operations. Excessive exposure to oxidixing atmospheres at temperatures above 650 to $700^{\circ} \mathrm{C}$ may result in excessive oxidation. Above $800^{\circ} \mathrm{C}$, scale formation in air can be quite rapid. Both oxygen and nitrogen are alpha stabilizers and show extensive solubility in the alpha phase. The two elements tend to embrittle titanium if present even in fairly small amounts. In air, oxygen contamination is negligible below about $540^{\circ} \mathrm{C}$. Below this temperature, only a thin oxide film may form, causing a discoloration of the surface, while 
above about $540^{\circ} \mathrm{C}$, a definite oxide scale can form, with the formation of both film and scale depending on temperature and time. The scale formed in air (reaction of titanium with oxygen and nitrogen) is very adherent, hard, and difficult to machine, and is usually removed by pickling in strong reducing acids. The scale formed at the higher temperatures is generally more readily removeable.

The formation of titanium hydride during the manufacture of the material is highly unlikely. But, the absorption of hydrogen from the environment with the formation of the hydride and followed by hydrogen-induced cracking is a distinct possibility. ${ }^{45}$ Hydrogen can only be removed by vacuum annealing. An extensive review on the effect of hydrogen on titanium was presented by Paton and Williams. ${ }^{47}$. These authors stated that with the advent of improved mill practice and fabrication procedures, the hydrogen content of the finished product has been steadily reduced, and failures due to hydrogen contamination are very rare.

\subsection{Forging}

The initial breakdown forging of titanium alloys is usually done at temperatures above the beta transus (transformation temperature to all beta), since the beta phase is more ductile than the alpha phase and forging-pressure requirements are lower. Final forging is usually done at temperatures below the beta transus to prevent excessive beta grain growth, which results in a loss in ductility. Variations in strain rate have little effect on forgeability. The alpha and alpha-beta alloys are readily forgeable with either presses or hammers. For commercially pure titanium (as well as a number of the alloys), the initial breakdown of the ingot is carried out at temperatures between 925 and $1090^{\circ} \mathrm{C}$.

Die forging of unalloyed grades is readily accomplished with blocking (forging with dies used to form a specific part) temperatures in the range of 870 to $925^{\circ} \mathrm{C}$ and finishing between 815 to $870^{\circ} \mathrm{C}$ (below the beta transus). For Ti-Grade 12, the recommended blocking temperature range is 900 to $925^{\circ} \mathrm{C}$. Finishing below the beta transus will result in more uniform properties. As with the annealing processes, slightly oxidizing atmospheres must be used to minimize hydrogen pickup. Any scale or contaminated surfaces must be removed following any operation at elevated temperatures. 


\subsection{Forming}

Ti-Grades 12 and 7 can be both cold and hot formed. The alloys can be cold formed on equipment used for stainless steels and for other titanium alloys. Ti-Grade 12 can be considered as being similar to Ti-Grade 3 for ductility and bendability. For design purposes, a minimum bend radius of twice the section thickness is appropriate at room temperature. Tighter radii require preheating to about $150^{\circ} \mathrm{C}$.

Forming of titanium is best accomplished by one of four basic methods: hydropress, power brake, stretch, or drop hammer. ${ }^{44}$ The method used will be governed largely by the configuration of the end product. Pressures should be applied more gradually than with steels. Blanks should be deburred to a round smooth edgę to prevent the appearance of cracks or tears during the forming operation. Hot forming of titanium sheet is usually preferred over cold forming. In hot forming, the titanium blanks are heated so that the actual deformation takes place at 200 to $315^{\circ} \mathrm{C}$ for the commercially pure grades and at 425 to $700^{\circ} \mathrm{C}$ for the alloyed grades. Stress-relief heat treatments should be performed between cold-forming stages and following the final cold-forming operation.

The most important reason for hot forming titanium is to minimize springback and residual stresses associated with forming at lower temperatures. Hot forming also improves the forming characteristics of titanium by increasing its ductility. Variations in yield strengths between different heats of the same alloy are reduced on forming at elevated temperatures, allowing for greater uniformity in formed parts. Such advantages are also obtained, but to a lesser degree, by warm working $\left(150\right.$ to $\left.260^{\circ} \mathrm{C}\right)$.

With the alpha phase having an hexagonal close-packed crystal structurc, textures (crystallographic alignments) and corresponding anisotropic properties are readily developed following unidirectional working of titanium, such as by cold rolling. The variations in ductility and yield strength, associated with the preferred textures, can affect the uniformity of a part being formed. An extensive treatise on textures and its effect on properties in titanium and its alloys was presented by Larson and Zarkades. 48

\subsection{Handling and Cleaning}


All foreign material, such as stencil marks, grease, oil, solvents, solvent residues, and scrapings from straightening tools, should be removed before any heating operation associated with forming, heat treating, or welding. Surface oxides must be removed after hot forming. Surface oxides or scale should be removed before forming, as such coatings increase notch sensitivity during forming. Care must be taken to avoid nicks or scratches in blanks and parts. Such defects can lead to premature failure on forming the part or while in service. Foreign materials must be removed prior to any forming, heat-treating, or pickling operation.

Conventional cleaning, etching, and descaling procedures can be used. Specific details are covered in company specifications. Acid concentrations, temperatures, and etching rates should be carefully controlled to minimize local attack and dimensional changes. Heavy scale formed at elevated temperatures can be removed either by mechanical or chemical means. Mechanical descaling methods include tumbling, vapor blasting, and fine-grit blasting. Coarse-grit blasting and wire brushing should not be used due to the possibility of introducing stress risers. Small traces of scale remaining can be removed by hand, using fine emery grit (180 or finer). Thin oxide films can be removed by pickling in acid baths approved for use with titanium. Surfaces should first be cleaned to assure a uniform metal removal in etching bath.

\subsection{Machining and Grinding}

Much of what is presented in the following on machining was obtained from information provided by RMI Titanium Company. 44,49 Machining may be done by all customary methods, but specific procedures must take into account the physical characteristics common to titanium. Machinability of the commercial grades of titanium are comparable to that of the austenitic stainless steels, with the alloyed-titanium materials being somewhat more difficult. The low thermal conductivity of titanium can result in a rapid buildup of heat, unless proper application of coolants is used. The use of sharp and proper tools is vital. Dull tools will accentuate heat buildup causing galling and seizing, lcading to premature tool failure. Relatively slow speeds and heavy feeds must be used.

The modulus of elasticity of titanium is about half that of steel. Slender parts will tend to deflect under tool pressure, causing 
chatter, tool rubbing, and tolerance problems. Consequently, rigidity of the entire machine-tool system is of considerable importance.

The turning operation is done with little difficulty. Carbide tools are preferred, with the "straight" tungsten carbide grades of standard designations $\mathrm{C} 1$ through $\mathrm{C} 4$ giving the best results. If high-speed steels are used, the cobalt type appear to be the best. Cast alloy tools, such as Stellite, Tantung, and Rexalloy, are preferred over the cheaper grades of high speed steels.

Milling of titanium is a more difficult operation than that of turning. Climb milling is recommended over conventional milling in order to minimize the tendency for the chip to adhere or weld to a tooth. Since a cutter tooth mills only part of each revolution, the chips tend to adhere to the tooth during that part of the revolution that the tooth does not cut. On the next contact, when the chip is knocked off, the tooth can be damaged if it is welded to the chip. In climb milling, the cutter is in contact with the thinnest portion of the chip, minimizing the adherence problem. For slab milling, the work should move in the same direction as the cutting tool; for face milling, the teeth should emerge from the cut in the same direction that the work is fed. A water-base coolant is recommended.

Successful drilling can be accomplished with ordinary high-speed steel drills. It is important that the unsupported section of the drill be no longer than is necessary for the chips to flow unhampered through the flutes and out of the hole. Use of "Spiro-Point" drill grinding is recommended.

In grinding, both alundum and silicon carbide wheels are used. Wheel speeds should be lower than those used in conventional grinding of steels. Water-soluble oils or cutting fluids with a high flash point must be used for all machining and grinding operations. Because of the high heat that is generated, a low flash-point fluid could be ignited. Parts must be thoroughly cleaned with a nonchlorinated degreasing solvent prior to exposure to any subsequent operation at elevated temperatures. Methyl-ethyl-ketone (MEK) is the preferred solvent for cleaning. Cutting fluids containing halogens ( $\mathrm{Cl}, \mathrm{F}, \mathrm{Br}$, and I) should not be used, to avoid corrosion problems that may arise from the use of such fluids with titanium and its alloys. 


\subsection{Welding}

Molten titanium is extremely reactive with nitrogen, oxygen, and hydrogen, and can dissolve large quantities of these gases at temperatures above $540^{\circ} \mathrm{C}$. These three elements tend to embrittle the metal. Consequently, any welding method must include provisions for shielding the molten weld metal and the adjacent heat-affected zone from these gases to temperatures as low as 300 to $400^{\circ} \mathrm{C}$. The metal must also be protected against carbon contamination. The inert-gas tungsten-arc and inert-gas metal-arc processes, as well as laser, electron-beam, plasma-arc, resistance, spot, seam, and flash welding are methods used successfully for joining titanium and its alloys. Using the proper procedures, $\mathrm{Ti}$ Grades 7,12 , and 16 are readily weldable with any of these methods. Ductile welds cannot be obtained using oxyacetylene welding or other forms of welding that use active gases, electrode coatings or fluxes.

The gas tungsten-arc welding (GTAW) method is the one most commonly used for joining titanium and titanium alloys in thicknesses less than about $3.2 \mathrm{~mm} .50$. Gas metal-arc welding (GMAW) is usually used for thicknesses over $3.2 \mathrm{~mm}$. With GTAW, square-grooved butt joints can be welded without filler metal for thicknesses up to $2.5 \mathrm{~mm}$. For thicker parts, the joints should be grooved and filler metal is required. Hot-wire GTAW can be used for thicknesses greater than $6.4 \mathrm{~mm}$. Where possible, welding should be done in the flat position. GMAW is less costly than GTAW, especially for thicknesses over $12.7 \mathrm{~mm}$ due to the higher weld-metal deposition rates of the former process.

Plasma-arc welding (PAW) is faster than GTAW and can be used on thick sections, for example, as one-pass welding on plates up to 12.7 $\mathrm{mm}$ thick, using square-groove butt joints and the keyhole technique. In addition, the use of filler metal with PAW is optional for thicknesses less than $12.7 \mathrm{~mm}$. PAW is closely related to GTAW. Heat is produced by a constricted arc, either between a consumable electrode and a workpiece or between a nonconsumable tungsten elcctrode and a constricting orifice. The ionized gas issuing from the orifice provides some shielding, which may be supplemented from an auxiliary source. The joining of titanium has been one of the major applications of plasma-arc welding. 50 
In general, welding techniques with titanium and its alloys are similar to those used for the austenitic stainless steels, except with the added feature of a trailing shield to protect the weldment as it solidifies. The trailing shicld should cover the solidified weld and adjacent hot metal until they cool to below about 315 to $425^{\circ} \mathrm{C}$. The underside of the weld must also be protected. This is typically done by using a grooved backup bar filled with inert gas. Backup shielding devices, contoured to fit internal surfaces, may also be used for the larger structures. The torch is designed to allow the protective gas to flow through it and cover the molten metal.

Either argon or helium, or a mixture of the two is used as the shielding gas. Argon, being less costly, is more widely used. Because of the high purity $(99.985 \% \mathrm{~min})$ and low moisture content, liquid argon is preferred. The dew point of the argon must be below $-24^{\circ} \mathrm{C}$. Excessive flow rates, which may cause turbulence and entrapment of contaminants, must be avoided. To minimize moisture pickup, nonporous flexible gas hoses like Tygon or vinyl plastic should be used. A rubber hose absorbs air, and it must not be used. 50

The type of shielding used will affect the arc characteristics. 50 For example, at a given welding current, the arc voltage is much greater with helium than with argon. The heat liberated with helium is about twice that obtained with argon; consequently, with helium shielding, higher welding speeds and deeper penetrations can be obtained. Argon provides greater arc stability than that available with helium; thus, arc stability and weld-metal control are sacrificed on using only helium. A mixture of $75 \% \mathrm{Ar}-25 \% \mathrm{He}$ is frequently used as a compromise between stability and penetration for the shielding gas at the torch in automatic operations.

Both inert-gas-arc methods are adaptable to either manual or automatic welding of titanium. For manual gas-tungsten-arc welding, a water-cooled GTA torch equipped with a gas lens and a 19 $\mathrm{mm}$ ceramic gas cup should be used. 51

Spot- and seam-welding procedures for titanium are similar to those used on other metals. Inert-gas shielding is not required here. Satisfactory welds are possible, with a number of combinations of current, time, and electrode force and are determined by trial. It is suggested to start with welding parameters uscd for austenitic 
stainless steels, as the electrical and thermal conductivity of titanium are somewhat similar to these materials. 44,52

In resistance and pressure welding, air is eliminated by intimate contact between pieces to be joined. In flash welding, since the molten metal at the faying surfaces is expelled at the time the weld is consummated, gas shielding is generally not needed. Shielding may be required with complex or hollow shapes and forged cross sections. When possible, use clamped joints rather than tack welds as the latter require the same shielding as other welds.

The welder should be able to visually inspect both face and root sides of the weld to see that shielding was effective. The solidified metal should have a bright silvery appearance. Joints can be prepared by sawing, machining, or grinding. They must be smooth and free of crevices and overlaps that could trap dirt and cleaning solvents. Avoid excessive heat, such as may occur in grinding. Any burns (oxides) due to overheating must be removed. Do not use finishing methods that can contaminate the weld with loosened particles, for example, by using sandpaper or steel wool. Rotary mechanical deburrers (rotary files) are recommended.

Before welding, mill scale as well as any light-colored oxide should be removed by rotary filing or acid pickling in a $35 \% \mathrm{HNO}_{3}-5 \% \mathrm{HF}$ solution, and followed by a water rinse and then air dried. Grease and oils should be removed with a non-chlorinated degreasing solvent. The joint and workpiece must be meticulously cleaned on both sides of the joint at least $51 \mathrm{~mm}$ beyond the width of the gas trailing shield. Interpass cleaning is not necessary if the weld deposit is bright and silvery. Light-colored oxide films (light yellow to light blue) should be cleaned off with a stainless-steel wire brush. Contaminated beads (dark blue, purple, gray, and loose white deposits) should be completely removed by grinding and then cleaned before welding continues. As a general rule, if the surface oxide is heavy, the weld is contaminated.

Excellent welds can be obtained in a welding chamber under a protective atmosphere. This may be impractical, as well as costly and time-consuming, for closure of the large containers designed for the repository, especially with the multiple barrier design. Unless the chamber is made sufficiently large to accommodate all the components, it would require frequent purging of the chamber and replenishing of the protective atmosphere. 
Titanium welding normally does not require any preheat or postheat. Where the temperature is low or the humidity is high, preheating (35 to $65^{\circ} \mathrm{C}$ ) to eliminate moisture is recommended. Weldments, after thorough cleaning, may be stress relieved at $540^{\circ} \mathrm{C}$, for one hour per $25.4 \mathrm{~mm}$ of thickness. Post-weld heat treatments, however, are generally not required. The alpha and near-alpha alloys usually are welded in the annealed condition. In environments where the corrosion-resistant alloys, such as Ti-Grade 12 have been tested, the welds have shown corrosion resistance equivalent to the base metal.

\subsection{Weld-Filler Metals and Electrodes}

Matching filler metal is recommended for Ti-Grades 7 and 12 to maintain the corrosion resistance of the base metals. The recommended AWS grades are ERTi-0.20 Pd and ERTi-0.8 Ni-0.3 Mo, respectively. Correspondingly, the filler metal for Ti-Grade 16 is likely to be designated ERTi-0.05. Normally, the welding wire is acid cleaned before spooling and packaging. Nevertheless, wires should be checked for cleanliness with a white cloth or glove; if dirty, the wire must be cleaned with a non-chlorinated solvent. The die lubricant used for wire drawing is the most likely contaminant, and it is readily removed using an acetone-soaked, lint-free cloth. Pickling in a nitric-hydrofluric acid solution can also be used for cleaning. If, during welding, the wire is inadvertently taken out of the protective shield, the end should be clipped back about $12.7 \mathrm{~mm}$ to remove contaminated metal.

The recommended electrode is AWS 5.12-65T,51 which is a twopercent thoriated-tungsten electrode. The particular shape used will depend on welder preference.

\section{References}

1. J. C. Farmer, G. E. Gdowski, and R. D. McCright, "Corrosion Models for Prediction of Performance of High-Level Radioactive Waste Containers," Lawrence Livermore National Laboratory, Livermore, California, UCID-21756, November, 1991.

2. R. A. Van Konynenburg, W. G. Halsey, R. D. McCright, W. L. Clark, Jr., and G. E. Gdowski, "Selection of Canditate Materials for the Conceptual WastePackage Design for a Potential High-Level Nuclear-Waste Repository at Yucca Mountain," UCRL-ID-112058, Lawrence Livermore National Laboratory, Livermore, California, February, 1993. 
3. R. A. Van Konynenburg, R. D. McCright, A. K. Roy, and D. A. Jones, "Engineering Materials Characterization Report for the Yucca Mountain Site Characterization Project," 3, Corrosion Data and Modeling, UCRL-ID119564, Lawrence Livermore National Laboratory, Livermore, California, December, 1994.

4. R. A. Van Konynenburg, R. D. McCright, A. K. Roy, and D. A. Jones, "Engineering Materials Characterization Report for the Yucca Mountain Site Characterization Project," 1, Inroduction, History, and Current Candidates, UCRL-ID-119564, Lawrence Livermore National Laboratory, Livermore, California, December, 1994.

5. R. D. McCright, "Container Materials for High-Level Nuclear Waste at the Proposed Yucca Mountain Site," UCRL-JC-103726, Lawrence Livermore National Laboratory, Livermore, California, May, 1991.

6. D. W. Vinson, W. M. Nutt, and D. B. Bullen, "Survey of the Degradation Modes of Candidate Materials for High-Level Radioactive-Waste Disposal Containers-Iron-Base, Corrosion-Allowance Materials," UCRL-CR-120464, Lawrence Livermore National Laboratory, Livermore, California, May 1995.

7. J. C. Farmer, G. E. Gdowski, R. D. McCright, and H. S. Ahluwahlia, "Corrosion Models for Performance Assessment of High-Level Radioactive-Waste Containers," UCRL-JC-103517, Lawrence Livcrmore National Laboratory, Livermore, California, July, 1991.

8. G. A. Henshall, W. G. Halsey, W. I. Clarke, and R. D. McCright, "Modeling Pitting-Corrosion Damage of High-Level Radioactive-Waste Containers with Emphasis on the Stochastic Approach," UCRL-ID-111624, Lawrence Livermore National Laboratory, Livermore, California, January 1993.

9. K. O. Stein, E. S. Robitz, Jr., M. D. McAninch, D. P. Edmonds, and E. W. Russell, "Closure Development for High-Level Nuclear-Waste Containers for the Tuff Repository," UCRL-15964, Lawrence Livermore National Laboratory, Livermore, California, September 1990.

10. K. O. Stein, H. A. Domian, R. L. Holbrook, and D. F. LaCount, "Fabrication Development for High-Level Nuclear-Waste Containers for the Tuff Repository," UCRL-15965, Lawrence Livermore National Laboratory, Livermore, California, September 1990.

11. H. A. Domian, E. S. Robitz, Jr., C. C. Conrardy, M. D. McAninch, R. L. Fish, and E. W. Russell,"Status Report-Fabrication and Closure Development of Nuclear-Waste-Disposal Containers for the Yucca Mountain Project," UCRL-JC-107985, Lawrence Livermore National Laboratory, Livermore, California, October, 1991.

12. A. K. Roy, R. L. Fish, and R. D. McCright, "Waste Package Materials Selection Process," in Proceedings of the Fifth Annual International Conference on High-Level Radioactive-Waste Management, 2, Las Vegas, Nevada, May 22-26, 1994, pp 993-999. 
13. D. Stahl, K.J. McCoy, and R. D. McCright, "Impact of Thermal Loading on Waste Package Material Performance", in Proceedings of the Fifth Annual International Conference on High-Level Radioactive-Waste Management, 2, Las Vegas, Nevada, May 22-24994, pp 1000-1004

14. R. D. McCright, "Updated Candidate List for Engineered Barrier Materials." Draft, in preparation for publication.

15. R. A. Van Konynenburg, R. D. McCright, A. K. Roy, and D. A. Jones, "Engineering Materials Characterization Report for the Yucca Mountain Site Characterization Project," 2, Design Data, UCRL-ID-119564, Lawrence Livermore National Laboratory, Livermore, California, December, 1994.

16 D. C. Argawal, U. Heubner, and W. R. Herda, "Recent Alloy Development in the Ni-Cr-Mo Alloy System," in Proceedings of the First Pan American Corrosion and Protection Congress, Mar de Plata, Argentina, 25-30 October, 1992.

17. Haynes International Bulletin H-10693, 1984.

18. G. E. Gdowski, "Survey of Degradation Modes of Four Nickel-ChromiumMolybdenum Alloys," UCRL-ID-108330, Lawrence Livermore National Laboratory, Livermore, California, March, 1991.

19. M. J. Cieslak, T. J. Headlcy, and A. D. Romig, Jr., "The Welding Metallurgy of Hastelloy Alloys C-4, C-22, and C-276," Metall.Trans. A, 17A, November, 1986, pp 2035-2047.

20. F. G. Hodge, and H. S. Ahluwalia, "The Influence of Long-Term LowTemperature Aging on the Performance of Candidate High-Nickel Alloys for the Nuclear-Waste Repository," in $12^{\text {th }}$ International Corrosion Congress, September 19-24, 1993, Houston, Texas, 5B, pp 4031-4045.

21. M. J. Cieslak, G. A. Knorovsky, T. J. Headley, and A. D. Romig, Jr., "The Use of New PHACOMP in Understanding the Solidification Microstructure of Nickel-Base-Alloy Weld Metal",Metall.Trans. A, 17A, December 1986, pp 2107-2116.

22. S. J. Lukezich, and H. S. Ahluwalia, "The Corrosion Performance of Candidate High-Nickel Alloys for the Nuclear-Waste Repository," in Proceedings of the Topical Meeting on Nuclear Waste Packaging, Focus 91, September 30-October 2, Las Vegas Nevada, 1991, pp 170-176.

23. Haynes International Bulletin H-2019D, 1991.

24. Haynes International Bulletin H-2007A, 1993.

25. Haynes International Bulletin H-2010C, 1988.

26. "Guidelines for the Welded Fabrication of Nickel Alloys for CorrosionResistant Service," Nickel Development Institute, Reference Book Series Number 11012, 1994. 
27. S. D. Kaiser, "Welding high-Nickel Alloys: Different but Not Difficult," Welding Journal, (10), 1988, pp 55-57.

28. N. Stephenson, "Versatility of Highly Alloyed Ni-Cr-Mo Welding Consumables," in Nickel Development Institute, NiDI Reprint Series Number 104011, reprinted from Welding and Metal Fabrication, 58, (7 and 8), 1990.

29. A. Garner, "The Effect of Autogenous Welding on Chloride-Pitting Corrosion in Austenitic Stainless Steels," Corrosion, 23, (3),1979, pp 108-114.

30. Cabot Corporation (now Haynes International),, Inc.,"Hastelloy G-3," Bulletin H-2009A, 1983.

31. INCO Alloys International,"INCO Alloy G-3," Bulletin 4M IAI-4, December, 1990.

32. INCO Alloys International,"INCO Alloy 825" Bulletin 5M 8-92 IAI-32-1, August, 1992

33. M. J. Strum, H. Weiss, J. C. Farmer, and D. B. Bullen, "Weldability of Austenitic Alloys," in Survey of Degradation Modes of Candidate Materials for High-Level Radioactive-Waste Disposal Containers, UCID-21362, 7, Lawrence Livermore National Laboratory, Livermore, California, June, 1998.

34. INCO Alloys International, "Welding," Bulletin IAI 14-1/3M, 1994.

35. INCO Alloys International, "Fabricating," Bulletin 6M 8-92 IAI-21, August 1992

36 INCO Alloys International, "Machining," Bulletin IAI 37/6M, 1994.

37. "Arc Welding of Nickel Alloys," in Welding and Brazing, ASM Metals Handbook, Eigth Edition. 6, American Society for Metals, Cleveland, Ohio, 1971, pp 366-374.

38. INCO Alloys International, "Welding Products," Bulletin IAI -27$3 / 5 \mathrm{M} / 1994$.

39. H. B. Bomberger, "The Corrosion Resistanc of Titanium," in Titanium and Titanium Alloys Source Book, Consulting Ed. M. J. Donachie, Jr., Publ. American Society for Metals, Cleveland, Ohio, 1982, pp 161-166.

40. R. W. Schutz, "Recent Titanium Alloy and Product Development for Corrosive Industrial Service," Paper Number 244, Corrosion 95, The NACE International Annual Conference and Corrosion Show, National Association of Corrosion Engineers, 1995. pp 244/1-244/20.

41. G. E. Gdowski and R. D. McCright, "Degradation Mode Surveys of HighPerformance Candidate-Container Materials," in Proceedings of the 
Second Annual International Conference on High-Level Radioactive-

Waste Managment, 2, Las Vegas, Nevada, April 28- May 3, 1994.

42. R. W. Schutz and M. Xiao, "Optimized Lean-Pd Titanium Alloys for Aggressive Reducing-Acid and Halide Service Environments," $12^{\text {th }}$ International Corrosion Congress, Houston, Texas, September 19-24, 1993, National Association of Corrosion Engineers.

43. R. W. Schutz, J. A. Hall, and T. L. Wardlaw, "Ti-Code 12, an Improved Industrial Alloy," in Proceed. of the 30th Anniversary Symposium of Japan Titanium Society, Kobe, Japan, November 15-18, 1982, pp 73-78.

44. RMI Titanium Company, "Basic Design Facts about Titanium", undated.

45. G. E. Gdowski and H. S. Ahluwalia, "Degradation Mode Survey of TitaniumBase Alloys," Lawrence Livermore National Laboratory, Livermore, California, January 30, 1995.

46. RMI Titanium Company, Property Data Sheet for Grade 12 Titanium, 1987.

47. N. E. Patton and J. C. Williams, "Effect of Hydrogen on Titanium and its Alloys," in Titanium and Titanium Alloys Source Book, American Society for Metals, Metals Park, Ohio, 1982, pp 185-207.

48. F. Larson and A. Zarkades, MCIC Report 74-20, Metals and Ceramic Information Center, Battelle Columbus Laboratories, Columbus, Ohio, June, 1974 .

49. RMI Titanium Company, "Facts About Machining Titanium," Bulletin $4 / 68,1968$.

50. M. J. Donachie, Jr., "Joining," in Titanium: A Technical Guide, Chapter 10, American Society for Metals, Metals Park, Ohio, 1988, pp 131-156.

51. J. Inskeep, J. A. McMaster,and C. A. Trumbell, "Move Over for Titanium," Welding Design and Fabrication, April 1977, pp 88-94.

52. RMI Titanium Company, "Facts about Welding Titanium", 1986.

53. D. C. Agarwal, G. K. Grossmann and R. Kirchheiner, "Two New Alloys in Waste Incineration Systems, UNS N06059 \& UNS N08031, Recent Experiences from Field Exposures," Paper Number 210, Corrosion 93, National Association of Corrosion Engineer Annual Conference and Corrosion Show, March, 1993.

54. M. L. Caruso, "The Corrosion Performance of Candidate Nuclear-Waste Containment Materials in a Simulated Repository Environment under Heat-Flux Conditions," M. S. Thesis, Ohio State University, Columbus, Ohio, 1993.

55. D. C. Agarwal and W. Herda,"Nickel-Base Alloys Combat Corrosion," Advanced Materials and Processes, 147, (6)1995, pp 25-28. 
56. R. D. Kane, M. Watkins, D. F. Jacobs, and G. L. Hancock, "Factors Influencing The Embrittlement of Cold-Worked High-Alloy Materials in $\mathrm{H}_{2} \mathrm{~S}$ Environments," Corrosion, 33, (9), 1977, pp 309-320.

57. RMI Titanium Company, "Crevice Corrosion Resistance of Titanium and Titanium Alloys to Aqueous Salt Solutions," Bulletin 7902. 
TABLE 1. COMPOSITION OF J-13 WELL WATER

\begin{tabular}{|c|c|}
\hline Species & Concentration (mg/l) \\
\hline $\mathrm{Na}$ & 45.8 \\
\hline $\mathrm{Si}$ & 28.5 \\
\hline $\mathrm{Ca}$ & 13.0 \\
\hline $\mathrm{K}$ & 5.04 \\
\hline $\mathrm{Mg}$ & 2.01 \\
\hline $\mathrm{B}$ & 0.134 \\
\hline $\mathrm{Li}$ & 0.048 \\
\hline $\mathrm{HCO}_{3}^{-}$ & 128.9 \\
\hline $\mathrm{SO}_{4}^{2-}$ & 18.4 \\
\hline $\mathrm{NO}_{3}^{-}$ & 8.78 \\
\hline $\mathrm{Cl}^{-}$ & 7.14 \\
\hline $\mathrm{F}^{-}$ & 2.18 \\
\hline \multicolumn{2}{|c|}{$\mathrm{pH}=7.41$} \\
\hline
\end{tabular}


TABLE 2. CANDIDATE MATERIALS FOR MULTI-BARRIER CONTAINERS

\begin{tabular}{|c|c|c|c|}
\hline \multicolumn{4}{|c|}{ CORROSION-RESISTANT MATERIALS } \\
\hline UNS No. & $\begin{array}{l}\text { Common or Commercial } \\
\text { Name }\end{array}$ & ASTM Number & Nominal Composition-Wt.\% \\
\hline \multicolumn{4}{|c|}{ Nickel-rich Superaustenitic-Stainless Alloys } \\
\hline N08825 & Alloy 825 ; Incoloy 825 & B 424 (plate) & $\begin{array}{l}\text { Ni 38.0-46.0; Cr 19.5-23.5; Mo 2.5-3.5; Fe balance; Cu 1.5-3.0; Ti 0.6-1.2; Mn } 1.0 \text { max; C } 0.05 \\
\text { max; Si 0.5 max; S 0.03 max; Al 0.2 max }\end{array}$ \\
\hline N06985 & Alloy G-3; INCO Alloy G-3 & B 582 (plate) & $\begin{array}{l}\text { Ni balance; Cr 21-23.5; Mo 6.0-8.0; Fe 18.0-21.0; W } 1.5 \max ; \text { Co } 5.0 \max ; \mathrm{Cu} 1.5-3.0 ; \mathrm{Nb}+\mathrm{Ta} \\
0.5 \mathrm{max} \text {; Mn } 1.0 \mathrm{max} \text {; C 0.015 max; Si } 1.0 \mathrm{max} ; \text { S } 0.03 \text { max; P 0.04 max }\end{array}$ \\
\hline \multicolumn{4}{|r|}{ Nickel-base (Ni-Cr-Mo) Alloys } \\
\hline N06022 & Alloy C-22; Hastelloy C-22 & B 575 (plate) & $\begin{array}{l}\text { Ni balance; Cr 20.0-22.0; Mo 12.5-14.5; Fe 2.0-6.0; W 2.5-3.5; Co } 2.5 \text { max; Mn } 0.5 \text { max; C } \\
0.010 \text { max; Si } 0.08 \text { max; V 0.35 max; S 0.02 max; P 0.02 max }\end{array}$ \\
\hline N06455 & Alloy C-4; Hastelloy C-4 & B 575 (plate) & $\begin{array}{l}\text { Ni balance; Cr 14.0-18.0; Mo 14.0-17.0; Fe } 3.0 \text { max; Co } 2.0 \text { max; Mn } 1.0 \text { max; C } 0.010 \text { max; Si } \\
0.08 \text { max; Ti 0.7 max; S 0.010 max; P 0.025 max }\end{array}$ \\
\hline \multicolumn{4}{|r|}{ Titanium-base Alloys } \\
\hline R53400 & Ti-Grade 12 & B 265 Grade 12 & $\begin{array}{l}\text { Ti balance; Ni } 0.6-0.9 ; \text { Mo } 0.2-0.4 ; \text { N } 0.03 \text { max; H } 0.015 \text { max; Fe } 0.30 \text { max; O } 0.25 \text { max; other, } \\
\text { each } 0.05 \text { max; other; total } 0.30 \text { max }\end{array}$ \\
\hline None to date & Ti-Grade 16 & B 265 Grade 16 & Ti balance; $0.05 \mathrm{Pd} ; \mathrm{N} 0.03 \mathrm{max} ; \mathrm{H} 0.015 ; \mathrm{Fe} 0.30 \mathrm{max} ; \mathrm{O} 0.25 \max ; \mathrm{C} 0.10 \mathrm{max}$ \\
\hline \multicolumn{4}{|c|}{ MODERATELY CORROSION-RESISTANT (INTERMEDIATE) MATERIALS } \\
\hline \multicolumn{4}{|r|}{ Copper and Nickel Alloys } \\
\hline N04400 & Alloy 400; Monel 400 & B 127 (plate) & Ni $63.0 \mathrm{~min} ; \mathrm{Cu} 28.0-34.0 ; \mathrm{Fe} 2.5 \max ; \mathrm{Mn} 2.0 \mathrm{max} ; \mathrm{C} 0.03 \mathrm{max} ; \mathrm{Si} 0.5 \mathrm{max} ; \mathrm{S} 0.024 \mathrm{max}$ \\
\hline C71500 & 70-30 Cupronickel; CDA 715 & B 171 (plate) & $\begin{array}{l}\text { Cu balance; Ni 29.0-33.0; Mn 1.0 max; Pb 0.02 max; Fe 0.4-1.0; Zn 0.5 max; C } 0.05 \text { max P } \\
0.02 \text { max; S 0.02 max }\end{array}$ \\
\hline \multicolumn{4}{|c|}{ CORROSION-ALLOWANCE MATERIALS } \\
\hline \multicolumn{4}{|c|}{ Low-Carbon and Low-Carbon-Low-Alloy Steels } \\
\hline G10200 & 1020 Carbon Steel & A 516 (Grade 55) & Fe balance; C 0.22 max; Mn 0.60-1.20; Si 0.15-0.40; S 0.04 max; P 0.35 max \\
\hline $\mathrm{J} 02501$ & Centrifugally Cast Steel & A 27 (Grade 70-40) & Fe balance;.C $0.25 \max ;$ Mn $1,20 \max ;$ Si $0.80 \max ;$ S 0.60 max; P $0.050 \max$ \\
\hline K21590 & $2 / 4 \mathrm{Cr}-1 \mathrm{Mo}$ Alloy Steel & A 387 (Grade 22) & Fe balance; Cr 2.00-2.50; Mo 0.90-1.10; C 0.15 max; Mn 0.30-0.60 Si 0.50 max; S 0.035 max \\
\hline
\end{tabular}


TABLE 3. AVERAGE MECHANICAL PROPERTIES OF CANDIDATE CORROSION-RESISTANT ALLOYS ${ }^{+}$

\begin{tabular}{|c|c|c|c|c|c|c|c|c|c|c|c|c|c|c|c|c|}
\hline \multirow[b]{2}{*}{ Alloy } & \multicolumn{4}{|c|}{$\begin{array}{l}\text { Young's Modulus-10 } 6 \text { psi } \\
(\mathrm{GPa}) \text { Temperature- }{ }^{\circ} \mathrm{C}\end{array}$} & \multicolumn{4}{|c|}{$\begin{array}{l}0.2 \% \text { Offset Yield Strength- } \\
\text { ksi }(\mathrm{MPa}) \text { Temperature- }{ }^{\circ} \mathrm{C}\end{array}$} & \multicolumn{4}{|c|}{$\begin{array}{ll}\text { Tensile } & \text { Stress-ksi } \\
(\mathrm{MPa}) & \text { Temperature- }^{\circ} \mathrm{C}\end{array}$} & \multicolumn{4}{|c|}{$\begin{array}{l}\text { Elongation-\% } \\
\text { Temperature- }{ }^{\circ} \mathrm{C}\end{array}$} \\
\hline & 25 & 100 & 200 & 300 & 25 & 100 & 200 & 300 & 25 & 100 & 200 & 300 & 25 & 100 & 200 & 300 \\
\hline 825 & $\begin{array}{r}29.8 \\
(206) \\
\end{array}$ & $\begin{array}{r}29.2 \\
(201)\end{array}$ & $\begin{array}{c}28.3 \\
(19.5) \\
\end{array}$ & $\begin{array}{c}27.3 \\
(18.8) \\
\end{array}$ & $\begin{array}{c}47^{*} \\
(324) \\
\end{array}$ & $\begin{array}{c}40^{*} \\
(276) \\
\end{array}$ & $\begin{array}{c}36^{*} \\
(248) \\
\end{array}$ & $\begin{array}{l}34^{*} \\
(234)\end{array}$ & $\begin{array}{l}100^{*} \\
(689) \\
\end{array}$ & $\begin{array}{l}95^{*} \\
(655) \\
\end{array}$ & $\begin{array}{l}92^{*} \\
(634)\end{array}$ & \begin{tabular}{|l}
$91^{*}$ \\
$(627)$ \\
\end{tabular} & $45^{*}$ & $44^{*}$ & $45^{*}$ & $41^{*}$ \\
\hline G-3** & $\begin{array}{r}28.9 \\
(119) \\
\end{array}$ & $\begin{array}{l}28.3 \\
(195)\end{array}$ & $\begin{array}{c}27.6 \\
(190)\end{array}$ & $\begin{array}{l}26.7 \\
(184)\end{array}$ & $\begin{array}{l}45 \\
(310)\end{array}$ & $\begin{array}{l}40 \\
(276)\end{array}$ & $\begin{array}{c}33 \\
(228)\end{array}$ & $\begin{array}{l}30 \\
(207)\end{array}$ & $\begin{array}{l}100 \\
(689)\end{array}$ & $\begin{array}{l}93 \\
(641)\end{array}$ & $\begin{array}{l}87 \\
(600)\end{array}$ & $\begin{array}{l}83 \\
(572)\end{array}$ & 58 & 60 & 62 & 64 \\
\hline$C-4^{\#}$ & $\begin{array}{r}30.8 \\
(212) \\
\end{array}$ & $\begin{array}{r}30.1 \\
(208) \\
\end{array}$ & $\begin{array}{r}29.3 \\
(202) \\
\end{array}$ & $\begin{array}{r}28.4 \\
(196)\end{array}$ & $\begin{array}{c}49 \\
(338)\end{array}$ & $\begin{array}{c}43 \\
(297) \\
\end{array}$ & $\begin{array}{c}38 \\
(262)\end{array}$ & $\begin{array}{c}36 \\
(248)\end{array}$ & $\begin{array}{l}117 \\
(807)\end{array}$ & $\begin{array}{l}110 \\
(758)\end{array}$ & $\begin{array}{l}105 \\
(724)\end{array}$ & $\begin{array}{l}103 \\
(710)\end{array}$ & 63 & 70 & 61 & 65 \\
\hline C-22 & $\begin{array}{r}29.9 \\
(206)\end{array}$ & $\begin{array}{l}293 \\
(202)\end{array}$ & $\begin{array}{c}28.4 \\
(196)\end{array}$ & $\begin{array}{r}27.4 \\
(188)\end{array}$ & $\begin{array}{c}54^{\neq} \\
(372)\end{array}$ & $\begin{array}{l}48^{\neq} \\
(331)\end{array}$ & $\begin{array}{c}42^{\neq} \\
(290)\end{array}$ & $\begin{array}{c}36^{\neq} \\
(248)\end{array}$ & $\begin{array}{l}114^{\neq} \\
(786)\end{array}$ & $\begin{array}{l}106^{\neq} \\
(731)\end{array}$ & $\begin{array}{c}99 \neq \\
(683)\end{array}$ & $\begin{array}{c}95^{\neq} \\
(655)\end{array}$ & $62^{\neq}$ & $65^{\neq}$ & $66^{\neq}$ & $68^{\neq}$ \\
\hline Ti Gr $12^{2}$ & $\begin{array}{r}15.2 \\
(105)\end{array}$ & $\begin{array}{r}14.7 \\
(101)\end{array}$ & $\begin{array}{l}14.1 \\
(97)\end{array}$ & $\begin{array}{l}12.9 \\
(89)\end{array}$ & $\begin{array}{c}65 \\
(448)\end{array}$ & $\begin{array}{c}51 \\
(352)\end{array}$ & $\begin{array}{c}42 \\
(290)\end{array}$ & $\begin{array}{c}35 \\
(241)\end{array}$ & $\begin{array}{c}72 \\
(496)\end{array}$ & & & $\begin{array}{l}47 \\
(324)\end{array}$ & 25 & & & 32 \\
\hline Ti Gr 16 & & & & & $\begin{array}{c}40^{x} \\
(275)\end{array}$ & & & & $\begin{array}{c}50^{x} \\
(345)\end{array}$ & & & & $20^{x}$ & & & \\
\hline Ti Gr $7^{2}$ & $\begin{array}{r}15.2 \\
(105)\end{array}$ & $\begin{array}{r}14.7 \\
(101)\end{array}$ & $\begin{array}{r}14.1 \\
(97)\end{array}$ & $\begin{array}{r}12.9 \\
(89)\end{array}$ & $\begin{array}{c}51 \\
(352)\end{array}$ & $\begin{array}{l}35 \\
(241)\end{array}$ & $\begin{array}{c}23 \\
(159)\end{array}$ & $\begin{array}{c}17 \\
(117)\end{array}$ & $\begin{array}{c}57 \\
(393)\end{array}$ & & & $\begin{array}{l}27 \\
(186)\end{array}$ & 28 & & & 37 \\
\hline \multicolumn{17}{|c|}{$\begin{array}{l}\text { + Values obtained or interpolated from data provided in bulletins and Alloy Digests published by producers/distributors } \\
\text { * solution-annealed bar } \\
\text { ** solution-annealed plate } \\
\text { \# solution-annealed } 1 / 2 \text {-inch plate } \\
\text { \# solution annealed } 1 / 4 \text { - to } 3 / 4 \text {-inch plate } \\
\times \text { ASTM B minimum tensile requirements } \\
\text { z Modulii are average values; actual values depend on texture/orientation; ranges at } 25^{\circ} \mathrm{C} \text { are } 15.0 \times 10^{6}-15.5 \times 10^{6} \mathrm{psi}(10\end{array}$} \\
\hline
\end{tabular}


TABLE 4. HAYNES INTERNATIONAL HASTELLOY FAMILY OF CORROSION-RESISTANT ALLOYS

\begin{tabular}{|c|c|c|}
\hline Alloy & Composition & Main Characteristics \\
\hline $\begin{array}{l}\text { Hastelloy B-2 } \\
\text { (N10665) }\end{array}$ & $\begin{array}{l}\text { 69Ni(bal)-1Cr(max)-28Mo-2Fe(max)-1Co(max)-1Mn(max)- } \\
0.1 \mathrm{Si}(\max )-0.01 \mathrm{C}(\max ) \text {. }\end{array}$ & $\begin{array}{l}\text { Superior resistance to hydrochloric acid, aluminum chloride catalysts, } \\
\text { and other strongly reducing chemicals. Excellent high-temperature } \\
\text { strength in inert atmospheres or vacuum. }\end{array}$ \\
\hline $\begin{array}{l}\text { Hastelloy C-4 } \\
\text { (N06455) }\end{array}$ & $\begin{array}{l}\text { 65Ni(bal)-16Cr-16Mo-3Fe(max)-2Co(max)-1Mn(max)- } \\
0.08 \mathrm{Si}(\max )-0.01 \mathrm{C}(\max )-0.7 \mathrm{Ti}(\max ) .\end{array}$ & $\begin{array}{l}\text { High-temperature stability in the } 650 \text { to } 1040^{\circ} \mathrm{C} \text { range as evidenced by } \\
\text { good ductility and corrosion resistance. Virtually the same excellent } \\
\text { corrosion resistance as Alloy C-276. }\end{array}$ \\
\hline $\begin{array}{l}\text { Alloy C-22 } \\
\text { (N06022) }\end{array}$ & $\begin{array}{l}56 \mathrm{Ni}(\mathrm{bal})-22 \mathrm{Cr}-13 \mathrm{Mo}-3 \mathrm{Fe}-2.5 \mathrm{Co}(\max )-0.5 \mathrm{Mn}(\max )- \\
0.08 \mathrm{Si}(\max )-0.01 \mathrm{C}(\max )-3 \mathrm{~W}-0.3 \mathrm{~V}(\max ) .\end{array}$ & $\begin{array}{l}\text { Better overall corrosion resistance and versatility than Alloys C-4,.C- } \\
276, \text { and } 625 \text {. Outstanding resistance to localized corrosion, stress- } \\
\text { corrosion cracking, and both oxidizing and reducing chemicals. Best } \\
\text { alloy to use as a universal weld-filler metal to resist corrosion of } \\
\text { weldments. }\end{array}$ \\
\hline $\begin{array}{l}\text { Hastelloy C-276 } \\
\text { (N10276) }\end{array}$ & $\begin{array}{l}57 \mathrm{Ni}(\mathrm{bal})-16 \mathrm{Cr}-16 \mathrm{Mo}-5 \mathrm{Fe}-2.5 \mathrm{Co}(\max )-1 \mathrm{Mn}(\max )- \\
0.08 \mathrm{Si}(\max )-0.01 \mathrm{C}(\max )-4 \mathrm{~W}-0.3 \mathrm{~V}(\max ) .\end{array}$ & $\begin{array}{l}\text { Versatile corrosion-resistant alloy. Excellent resistance to both } \\
\text { oxidizing and reducing corrosives, mixed acids, and chlorine- } \\
\text { contaminated hydrocarbons. }\end{array}$ \\
\hline $\begin{array}{l}\text { Alloy G-30 } \\
\text { (N06030) }\end{array}$ & $\begin{array}{l}\text { 43Ni(bal)-30Cr-5.5Mo-15Fe-5Co(max)-1.5Mn(max)- } \\
1.0 \mathrm{Si}(\max )-0.03 \mathrm{C}(\max )-2.5 \mathrm{~W}-1.5 \mathrm{Nb}(\max )-2 \mathrm{Cu}(\max ) .\end{array}$ & $\begin{array}{l}\text { Many advantages over other metallic and non-metallic materialsin } \\
\text { handling phosphoric acid, sulfuric acid, nitric acid, fluoride } \\
\text { environments, and oxidizing-acid mixtures. }\end{array}$ \\
\hline $\begin{array}{l}\text { Alloy G-50 } \\
\text { (N06950) }\end{array}$ & $\begin{array}{l}50 \mathrm{Ni}(\min \mathrm{bal})-20 \mathrm{Cr}-9 \mathrm{Mo}-17 \mathrm{Fe}-2.5 \mathrm{Co}(\max )-1 \mathrm{Mn}(\max )- \\
1 \mathrm{Si}(\max )-0.02 \mathrm{C}(\max )-1 \mathrm{~W}(\max )-0.5 \mathrm{Nb}(\max )-0.5 \mathrm{Cu}(\max )- \\
0.4 \mathrm{Al}(\max )\end{array}$ & $\begin{array}{l}\text { Excellent resistanc to stress-corrosion cracking in aggressive sour-gas } \\
\text { environments. Mostly used as production tubing with yield strength } \\
\text { in the range of } 110 \text { to150 ksi. }\end{array}$ \\
\hline $\begin{array}{l}\text { Alloy H-9M } \\
\text { (N06920) }\end{array}$ & $\begin{array}{l}\text { 45Ni(bal)-22Cr-9Mo-19Fe-5Co(max)-1Mn(max)-1Si(max)- } \\
0.03 \mathrm{C}(\max )-2 \mathrm{~W}\end{array}$ & $\begin{array}{l}\text { Equivalent or better localized corrosion resistance compared to Alloy } \\
625 \text {, but, it is in a price range close to those of the superaustenitic } \\
\text { stainless steels. The alloy also has good resistance to hot acids and } \\
\text { excellent resistance to stress-corrosion cracking. }\end{array}$ \\
\hline $\begin{array}{l}\text { Hastelloy } N \\
\text { (N10003) }\end{array}$ & $\begin{array}{l}71 \mathrm{Ni}(\mathrm{bal})-7 \mathrm{Cr}-16 \mathrm{Mo}-5 \mathrm{Fe}(\max )-0.2 \mathrm{Co}(\max )-0.8 \mathrm{Mn}(\max )-1 \mathrm{Si} \\
(\max )-0.08 \mathrm{C}(\max )-0.5 \mathrm{~W}(\max )-0.35 \mathrm{Cu}(\max )-0.5 \mathrm{Al}+\mathrm{Ti}(\max )\end{array}$ & $\begin{array}{l}\text { Good resistance to aging and embrittlement. It has good fabricability, } \\
\text { and excellent resistance to hot fluoride salts in the temperature range of } \\
704 \text { to } 870^{\circ} \mathrm{C} \text {. }\end{array}$ \\
\hline $\begin{array}{l}\text { Alloy } 59 \\
\text { (N06059) }\end{array}$ & $59 \mathrm{Ni}-23 \mathrm{Cr}-16 \mathrm{Mo}-1 \mathrm{Fe}$ & $\begin{array}{l}\text { Excellent thermal stability (tungsten-free). Improved corrosion } \\
\text { resistance in strong oxidizing media. Highest pitting index of the } \\
\text { nickel-chromium-molybdenum family of alloys. }\end{array}$ \\
\hline
\end{tabular}


TABLE 5. CORROSION RATES OF FOUR Ni-Cr-Mo ALLOYS

\begin{tabular}{|l|c|c|c|c|}
\hline \multicolumn{1}{|c|}{ Corrosive Medium } & \multicolumn{5}{|c|}{ Corrosion Rate-mils (mm) per year } \\
\hline $10 \% \mathrm{FeCl}_{2}$ Boiling & $1(0.025)$ & $2(0.050)$ & $140(3.500)$ & $>150(>3.75)$ \\
\hline $1.5 \% \mathrm{HCl}_{\text {Boiling }}$ & $11(0.275)$ & $29(0.725)$ & $65(1.625)$ & $>150(>3.75)$ \\
\hline $2.5 \% \mathrm{HCl} 90^{\circ} \mathrm{C}$ & $<1(0.025)$ & $12(0.300)$ & $34(0.850)$ & $72(1.800)$ \\
\hline $2 \% \mathrm{HF} \mathrm{70} \mathrm{C}$ & $9(0.225)$ & $9(0.225)$ & $17(0.425)$ & $20(0.500)$ \\
\hline $\begin{array}{l}5 \% \mathrm{HNO}_{3}+25 \% \mathrm{H}_{2} \mathrm{SO}_{4} \\
+4 \% \mathrm{NaCl}^{\circ} \text { Boiling }\end{array}$ & $12(0.300)$ & $64(1.600)$ & $97(2.425)$ & $>150(>3.75)$ \\
\hline $5 \% \mathrm{HNO}_{3}+1 \% \mathrm{HCl} \mathrm{Boiling}$ & $1(0.025)$ & $7(0.175)$ & $11(0.275)$ & $1.2(0.030)$ \\
\hline $10 \% \mathrm{H}_{2} \mathrm{SO}_{4}$ Boiling & $11(0.275)$ & $23(0.575)$ & $31(0.775)$ & $46(1.150)$ \\
\hline $50 \% \mathrm{H}_{2} \mathrm{SO}_{4} 66^{\circ} \mathrm{C}$ & $1(0.025)$ & $4(1.000)$ & $13(0.325)$ & $26(0.650)$ \\
\hline $5 \% \mathrm{H}_{2} \mathrm{SO}_{4}+0.1 \% \mathrm{HCl} \mathrm{Boiling}$ & $27(0.675)$ & $42(1.050)$ & $49(1.225)$ & $>150(>3.75)$ \\
\hline $25 \% \mathrm{H}_{2} \mathrm{SO}_{4}+200 \mathrm{ppm} \mathrm{Cl} 70^{\circ} \mathrm{C}$ & $11(0.275)$ & $12(0.300)$ & $37(0.925)$ & $>150(>3.75)$ \\
\hline $\begin{array}{l}25 \% \mathrm{H}_{2} \mathrm{SO}_{4}+1.2 \% \mathrm{HCl}^{\circ} \\
+1 \% \mathrm{FeCl}_{3}+1 \% \mathrm{CuCl}_{2} \text { Boiling }\end{array}$ & $7(0.175)$ & $55(1.375)$ & $>150(>3.75)$ & $>150(>3.75)$ \\
\hline
\end{tabular}


TABLE 6. COMPARISON OF CORROSION DATA FOR DIFFERENT CONDITIONS OF ALLOY C-4

\begin{tabular}{|c|c|c|c|c|c|}
\hline \multirow[b]{2}{*}{ Medium } & \multirow[b]{2}{*}{ Conc., wt.\% } & \multirow[b]{2}{*}{ Temp., ${ }^{\circ} \mathrm{C}$} & \multicolumn{3}{|c|}{$\begin{array}{l}\text { Average Corrosion Rate } \\
\text { mils (mm) per year }\end{array}$} \\
\hline & & & Unwelded* & As-Welded ${ }^{+}$ & Aged\# \\
\hline Formic acid & 20 & Boiling & $2.9(0.07)$ & $3.5(0.09)$ & $3.5(0.09)$ \\
\hline Hydrochloric Acid & 10 & 75 & $36(0.91)$ & $34(0.86)$ & $35(0.89)$ \\
\hline Nitric Acid & 10 & Boiling & $5.9(0.15)$ & $7.1(0.18)$ & $9.2(0.23)$ \\
\hline Phosphoric Acid & 85 & Boiling & $61(1.5)$ & $52(1.3)$ & $85(2.2)$ \\
\hline Sulfuric Acid & 10 & boiling & $22(0.56)$ & $25(0.64)$ & $20(0.51)$ \\
\hline Sulfuric Acid & 85 & 75 & $23(0.58$ & $17(0.43)$ & $21(0.53)$ \\
\hline $\begin{array}{l}\text { Hydrochloric Acid (2T } \\
\text { Rad. Bend Test) }\end{array}$ & 10 & Boiling & $250(6.25)$ & $285(7.2)$ & $276(7.0)$ \\
\hline \multicolumn{2}{|c|}{ ASTM G28 $\left(50 \% \mathrm{H}_{2} \mathrm{SO}_{4}+42 \mathrm{~g} \mathrm{FeSO}_{4}\right)$} & Boiling & $100(2.50)$ & $111(2.8)$ & $114(2.9)$ \\
\hline \multicolumn{6}{|c|}{$\begin{array}{l}\text { *Solution annealed at } 1066^{\circ} \mathrm{C} \text { and water quenched. } \\
\text { +Gas tungsten arc welded. } \\
\text { \#Aged } 100 \text { hours at } 899^{\circ} \mathrm{C}\end{array}$} \\
\hline
\end{tabular}


TABLE 7. GRINDING WHEELS FOR GRINDING Ni-Cr-Mo ALLOYS

\begin{tabular}{|c|c|c|c|c|}
\hline Type of Grinding & Wheels* & Manufacturer & Type of Work & Coolant \\
\hline \multicolumn{5}{|l|}{ Cylinder Grinding } \\
\hline $\begin{array}{l}\text { Straight or Tapered } \\
\text { O.D.'s }\end{array}$ & $53 A 80-18 V 127$ & Norton & $\begin{array}{l}\text { Sharp corners and } \\
\text { fine finish }\end{array}$ & $\begin{array}{l}\text { Heavy duty } \\
\text { soluble coolant } 25: 1 \mathrm{mix} \\
\text { CASTROL } 653\end{array}$ \\
\hline $\begin{array}{l}\text { Form Work, Single Wheel } \\
\text { Section Method }\end{array}$ & 38A60-J8-VBE & Norton & $\begin{array}{l}\text { Removing stock } \\
\text { Sharp corner work } \\
\text { Straight radius work }\end{array}$ & Dry \\
\hline $\begin{array}{l}\text { Form Work, Crush-Roll } \\
\text { Method }\end{array}$ & 53A220-L9VB & Norton & $\begin{array}{l}\text { Precision forms } \\
\text { Radius }\end{array}$ & Straight oil \\
\hline Centerless & 53A80-J8VCN & Norton & $\begin{array}{l}\text { Thin-walled material } \\
\text { Solid or heavy- } \\
\text { walled material }\end{array}$ & $\begin{array}{l}\text { Heavy duty } \\
\text { soluble coolant } 25: 1 \mathrm{mix} \\
\text { CASTROL } 653\end{array}$ \\
\hline \multicolumn{5}{|l|}{ Internal Grinding } \\
\hline Straight or Tapered & 23A54-L8VBE & Norton & $\begin{array}{l}\text { Small holes } \\
\text { Medium-size holes } \\
\text { Large holes } \\
\text { Small counterbores }\end{array}$ & $\begin{array}{l}\text { Heavy duty } \\
\text { soluble coolant 25:1 mix } \\
\text { CASTROL 709 }\end{array}$ \\
\hline \multicolumn{5}{|l|}{ Surface Grinding } \\
\hline Straight Wheel & $\begin{array}{l}\text { 32A46-H8VBE } \\
38 A 46-1-V\end{array}$ & $\begin{array}{l}\text { Norton } \\
\text { Norton }\end{array}$ & & $\begin{array}{l}\text { Dry or any heavy duty } \\
\text { soluble coolant } 25: 1 \text { mix } \\
\text { CASTROL } 653\end{array}$ \\
\hline $\begin{array}{l}\text { Double Opposed Disk } \\
\text { Type }\end{array}$ & $\begin{array}{l}\text { 87A46-G12-BV } \\
87 A 46-J 11-B W\end{array}$ & $\begin{array}{l}\text { Gardner } \\
\text { Gardner }\end{array}$ & $\begin{array}{l}\text { Through-feed work } \\
\text { Ferris wheel work } \\
\text { Thin work }\end{array}$ & $\begin{array}{l}\text { Heavy duty } \\
\text { soluble coolant 10:1 mix } \\
\text { CASTROL } 653\end{array}$ \\
\hline $\begin{array}{l}\text { Cylinder or Segmental } \\
\text { Type }\end{array}$ & 32A46-F12VBE & Norton & $\begin{array}{l}\text { Thin work, bevels } \\
\text { and close } \\
\text { tolerance work }\end{array}$ & $\begin{array}{l}\text { Sal-soda in water } \\
\text { CASTROL } 653\end{array}$ \\
\hline $\begin{array}{l}\text { Single Wheel Section } \\
\text { Method }\end{array}$ & 32A46-F12VBEP & Norton & Profile work & Dry \\
\hline \multicolumn{5}{|l|}{ Thread Grinding } \\
\hline External Threads & A100-T9BH & Norton & & $\begin{array}{l}\text { VANTOL 5299-M } \\
\text { or equivalent }\end{array}$ \\
\hline \multicolumn{5}{|l|}{ Honing } \\
\hline Internal & $\begin{array}{l}\text { C120-E12-V32 } \\
\text { C220-K } 4 \text { VE } \\
\text { J45-J57 }\end{array}$ & $\begin{array}{l}\text { Bay State } \\
\text { Carborundum } \\
\text { Sunnen }\end{array}$ & & $\begin{array}{l}\text { VANTROL } 5299-C \\
\text { or equivalent }\end{array}$ \\
\hline \multicolumn{5}{|l|}{ Rough Grinding } \\
\hline $\begin{array}{l}\text { Cut-off (Wet) } \\
\text { Cut-off (Dry) }\end{array}$ & $\begin{array}{l}\text { 86A461-LB25W } \\
\text { 4NZA24-TB65N } \\
\end{array}$ & $\begin{array}{l}\text { Norton } \\
\text { Norton }\end{array}$ & & $\begin{array}{l}\text { CASTROL } 653 \\
\text { Dry }\end{array}$ \\
\hline Snagging & 4ZF1634-Q5B38 & Norton & & Dry \\
\hline
\end{tabular}




\section{TABLE 8. CARBIDE TOOLS FOR MACHINING Ni-Cr-Mo ALLOYS}

Operations

Roughing, with severe interruptions;

Turning or Facing

Normal roughing

Turning or Facing

Carbide Tools

C-2 or C-3 grade: Negative rake square insert, $45^{\circ}$ SCEA $1 / 32$ in. nose radius. Tool holder: $5^{\circ}$ neg. back rake, $5^{\circ}$ neg. side rake.

Speed: $30-50 \mathrm{sfm}, 0.004-0.008$ in. feed, $0.150 \mathrm{in}$. depth of cut. Dry $^{2}$, oil $^{3}$, or water-base coolant.

C-2 or C-3 grade: Negative rake square insert, $45^{\circ}$ SCEA, $1 / 32$ in. nose radius. Tool holder: $5^{\circ}$ neg. back rake, $5^{\circ}$ neg. side rake.

Speed: $90 \mathrm{sfm}$ depending on rigidity of set up, $0.010 \mathrm{in}$. feed, 0.150 in. depth of cut.

Dry, oil, or water-base coolant.

Finishing:

Turning or Facing

C-2 or C-3 grade: Positive rake square insert, if possible, $45^{\circ}$ SCEA, $1 / 32$ in. nose radius.

Tool holder: $5^{\circ}$ pos. back rake, $5^{\circ}$ pos. side rake.

Speed: $95-110 \mathrm{sfm}, 0.005-0.007$ in. feed, $0.040 \mathrm{in}$. depth of cut.

Dry or water-base coolant.

Rough Boring

C-2 or C-3 grade: If insert type boring bar, use standard positive rake tools with largest possible SCEA and 1/16 in. nose radius. If brazed tool bar, grind $0^{\circ}$ back rake, $10^{\circ}$ pos. side rake, $1 / 32$ in. nose radius and largest possible SCEA.

Speed: $70 \mathrm{sfm}$ depending on the rigidity of setup, $0.005-0.008$ in. feed, $1 / 8$ in. depth of cut.

Dry, oil, or water-base coolant.

Finish Boring

C-2 or C-3 grade: Use standard positive rake tools on insert type bars. Grind brazed tools as for finish turning and facing except back rake may be best at 0 .

Speed: $95-110 \mathrm{sfm}, 0.002-0.004$ in. feed.

Water-base coolant.

NOTES: 1 SCEA - Side cutting edge angle or lead angle of the tool.

2 At any point where dry cutting is recommended, an air jet directed on the tool may provide substantial tool life increases. A water-base coolant mist may also be effective.

3 Oil coolant should be a premium quality, sulfochlorinated oil with extreme pressure additives. A viscosity at $100^{\circ} \mathrm{F}$ from 50 to $125 \mathrm{SSU}$.

4 Water-base coolant should be premium quality, sulfochlorinated water soluble oil or chemical emulsion with extreme pressure additives. Dilute with water to make 15:1 mix. Water-base coolant may cause chipping and rapid failure of carbide tools in interrupted cuts. 


\section{TABLE 9. HIGH-SPEED TOOLS FOR MACHINING Ni-Cr-Mo ALLOYS}

\begin{tabular}{|c|c|c|}
\hline Operations & High Speed Steel Tools & Carbide Tools \\
\hline Facing Milling & $\begin{array}{l}M-2, M-7, \text { or } M-40 \text { series }^{5}: \text { Radial and } \\
\text { axial rake } 0^{\circ}-\text { pos. } 10^{\circ} 45^{\circ} \\
\text { corner angle, } 10^{\circ} \text { relief angle. } \\
\text { Speed: } 20-30 \mathrm{sfm} \text {. } \\
\text { Feed: } 0.003-0.005 \text { in. } \\
\text { Oil }{ }^{6} \text { or water-base coolant? }\end{array}$ & $\begin{array}{l}\text { Carbide not generally successful, } \\
\text { C-grade may work. Use positive axial } \\
\text { and radial rake, } 45^{\circ} \text { corner angle, } \\
10^{\circ} \text { relief angle. } \\
\text { Speed: } 50-60 \text { sfm. } \\
\text { Feed: } 0.005-0.008 \text { in. } \\
\text { Oil or water-base coolants will reduce } \\
\text { thermal shock damage of carbide } \\
\text { cutter teeth. }\end{array}$ \\
\hline End Milling & $\begin{array}{l}\text { M-40 series or T-15: If possible, } \\
\text { use short mills with } \\
4 \text { or more flutes for rigidity. } \\
\text { Speed: } 20-25 \text { sfm. } \\
\text { Feed: } 0.002 \text { in. tooth } 1 / 4 \text { in. dia. } \\
0.002 \text { in. tooth } 1 / 2 \text { in. dia. } \\
0.003 \text { in. tooth } 3 / 4 \text { in. dia. } \\
0.004 \text { in. tooth } 1 \text { in. dia. } \\
\text { Oil or water-base coolant. }\end{array}$ & $\begin{array}{l}\text { Not recommended, but C-2 grades may } \\
\text { be successful on good setups. } \\
\text { Use positive rake. } \\
\text { Speed: } 50-60 \text { sfm. } \\
\text { Feed: Same as high speed steel. } \\
\text { Oil or water-base coolants will reduce } \\
\text { thermal shock damage. }\end{array}$ \\
\hline Drilling & $\begin{array}{l}\text { M-33, M-40 series or T-15: Use short } \\
\text { drills, heavy web, } 135^{\circ} \text { crank-shaft, } \\
\text { grind points wherever possible. } \\
\text { Speed: } 10-15 \text { sfm. } \\
\text { Feed: } 0.001 \text { in. rev. } 1 / 8 \text { in. dia. } \\
0.002 \text { in. rev. } 1 / 4 \text { in. dia. } \\
0.003 \text { in. rev. } 1 / 2 \text { in. dia. } \\
0.005 \text { in. rev. } 3 / 4 \text { in. dia. } \\
0.007 \text { in. rev. } 1 \text { in. dia. } \\
\text { Oil or water-base coolant. } \\
\text { Use coolant feed drills if possible. }\end{array}$ & $\begin{array}{l}\text { C-2 grade not recommended, but tipped } \\
\text { drills may be successful on rigid } \\
\text { setup if no great depth. The web } \\
\text { must be thinned to reduce thrust. } \\
\text { Use } 135^{\circ} \text { included angle on point. } \\
\text { Gun drill can be used. } \\
\text { Speed: } 50 \text { sfm. } \\
\text { Oil or water-base coolant. } \\
\text { Coolant-feed carbide tipped drills } \\
\text { may be economical in some setups. }\end{array}$ \\
\hline Reaming & $\begin{array}{l}\text { M-33, M-40 series or T-15: Use } 45^{\circ} \\
\text { corner angle, narrow primary } \\
\text { land and } 10^{\circ} \text { relief angle. } \\
\text { Speed: } 10-20 \text { sfm. } \\
\text { Feed: } 0.003 \text { in. tooth } 1 / 2 \text { in. dia. } \\
0.008 \text { in. tooth } 2 \text { in. dia. } \\
\text { Oil or water-base coolant. }\end{array}$ & $\begin{array}{l}\text { C-2 or C-3 grade: Tipped reamers } \\
\text { recommended, solid carbide } \\
\text { reamers require very good } \\
\text { setup. Tool geometry same } \\
\text { as high speed steel. } \\
\text { Speed: } 50 \text { sfm. } \\
\text { Feed: Same as high speed steel. }\end{array}$ \\
\hline Tapping & $\begin{array}{l}\text { M-1, M-7, M-10: } 2 \text { flute, spiral point, } \\
\text { plug tap } 0^{\circ}-10^{\circ} \text { hook angle } \\
\text { nitrided surface may be helpful } \\
\text { by increasing wear resistance } \\
\text { but may cause chipping } \\
\text { or breakage. Tap drill for } 60-65 \% \\
\text { thread, if possible, to increase } \\
\text { tool life. } \\
\text { Speed: } 7 \text { sfm (cutting). } \\
\text { Use best possible tapping compound, } \\
\text { sulfochlorinated oil base preferred. }\end{array}$ & Not recommended \\
\hline
\end{tabular}

Electrical

Discharge

HASTELLOY alloys can be easily cut using any conventional electrical discharge

Machining machining system (EDM) or wire EDM.

NOTES: 5 M-40 series High Speed Steels include $M-41, M-42, M-43, M-44, M-45$ and $M-46$ at the time of writing. 0thers may be added and should be equally suitable. 6 Oil coolant should be a premium quality, sulfochlorinated oil with extreme pressure additives. A viscosity at $100^{\circ} \mathrm{F}$ from 50 to $125 \mathrm{SSU}$.

7 Water-base coolant shoutd be premium quality, sulfochlorinated water soluble oil or chemical emulsion with extreme pressure addifives. Dilute with water to make $15: 1$ mix. 


\begin{tabular}{|c|c|c|}
\hline Process & Advantages & Disadvantages \\
\hline Friction Welding & $\begin{array}{l}\text { Small HAZ, small fusion zone, } \\
\text { minimum risk for second phases, } \\
\text { low residual stress, low } \\
\text { distortion, good inspectability, } \\
\text { ease of in-cell maintenance, low } \\
\text { frequency of maintenance, fast } \\
\text { weld speed, few welding } \\
\text { variables to monitor. }\end{array}$ & $\begin{array}{l}\text { ID and OD scarf (requires OD } \\
\text { machining) massive equipment, } \\
\text { expensive equipment, repair } \\
\text { difficult, (full reweld of second } \\
\text { process repair), may impact } \\
\text { container design, additional } \\
\text { safety considerations. }\end{array}$ \\
\hline Electron Beam Welding & $\begin{array}{l}\text { Low heat input,relatively small } \\
\text { fusion zone and HAZ, relatively } \\
\text { low residual stresses and } \\
\text { distortion, good inspectability, } \\
\text { fast weld speeds, chance for } \\
\text { repair welding without } \\
\text { machining, no filler metal. }\end{array}$ & $\begin{array}{l}\text { Could experience poor crown } \\
\text { surface condition and defects in } \\
\text { spike areas, expensive } \\
\text { equipment, in-cell vacuum } \\
\text { chamber required, in-cell } \\
\text { maintenance expensive, safety } \\
\text { considerations. }\end{array}$ \\
\hline Plasma Arc Welding & $\begin{array}{l}\text { Low to medium heat input, no } \\
\text { filler metal with keyhole, } \\
\text { relatively low-cost equipment, } \\
\text { much previous closure } \\
\text { experience, versatile equipment, } \\
\text { repair welding with same } \\
\text { process, arc length more } \\
\text { forgiving than with gas tungsten } \\
\text { arc welding. }\end{array}$ & $\begin{array}{l}\text { Many weld variables to monitor, } \\
\text { in-cell monitors (guidance and } \\
\text { real-time controls) could be } \\
\text { required, fairly complex torch, } \\
\text { possibility for porosity in } \\
\text { keyhole mode, medium } \\
\text { inspectability, higher possibility } \\
\text { for second phases if filler metal } \\
\text { is used, machining for repair } \\
\text { welding possibly required, }\end{array}$ \\
\hline Laser Beam Welding & Same as electron beam welding. & $\begin{array}{l}\text { Pushing current technology with } \\
\text { required material thicknesses, } \\
\text { expensive equipment, beam must } \\
\text { penetrate cell wall at some point, } \\
\text { maintenance could be expensive. }\end{array}$ \\
\hline Gas Tungsten Arc Welding & $\begin{array}{l}\text { Medium heat input, low-cost } \\
\text { equipment, fewer variables than } \\
\text { plasma arc welding, much } \\
\text { previous in-cell experience, } \\
\text { repair welding with same } \\
\text { equipment, easier in-cell } \\
\text { maintenance, less expensive than } \\
\text { all of the above processes. }\end{array}$ & $\begin{array}{l}\text { A greater volume of material } \\
\text { affected by high residual stresses } \\
\text { and greater distortions than all of } \\
\text { the above processes, filler metals } \\
\text { required, repairs require re- } \\
\text { machining, larger fusion zone } \\
\text { and larger HAZ, lower } \\
\text { inspectability, higher possibility } \\
\text { for second phases, in-cell } \\
\text { guidance and real-time controls } \\
\text { may be needed. }\end{array}$ \\
\hline
\end{tabular}


TABLE 11. RELATIVE MERITS OF THREE WELDING METHODS FOR WELDING OF NICKEL-BASED CORROSION-RESISTANT ALLOYS

\begin{tabular}{|c|c|c|}
\hline Process & Advantages & Disadvantages \\
\hline $\begin{array}{l}\text { Gas Tungsten Arc } \\
\text { Welding (GTAW) }\end{array}$ & $\begin{array}{l}\text { Very versatile, all-position process; } \\
\text { adapts to both manual and automatic } \\
\text { operations; offers great control; no } \\
\text { slag to remove; no weld splatter; no } \\
\text { alloy loss during welding; minimal } \\
\text { postweld surface cleanup/finishing; } \\
\text { most readily used for making small } \\
\text { repair welds; weld can be made by } \\
\text { fusion of the base metal without any } \\
\text { filler metal. }\end{array}$ & $\begin{array}{l}\text { Major drawback is low productivity; } \\
\text { manual weld-deposition rates are low. }\end{array}$ \\
\hline $\begin{array}{l}\text { Gas Metal Arc } \\
\text { Welding (GMAW) }\end{array}$ & $\begin{array}{l}\text { Provides considerable increase in } \\
\text { productivity over GTAW; suited for } \\
\text { both manual and automatic situations; } \\
\text { easily autimated; faster welding } \\
\text { speeds than GTAW and SMAW; } \\
\text { provides possibility for three modes } \\
\text { of metal transfer (short-circuiting, } \\
\text { globular, and spray transfer); constant } \\
\text { current, fixed frequency pulse, } \\
\text { variable slope/inductance, and } \\
\text { synergic welding power suppplies can } \\
\text { all be used; no slag formed; better } \\
\text { transfer of elements across arc as } \\
\text { compared to GTAW and SMAW. }\end{array}$ & $\begin{array}{l}\text { Control and ease of operation are } \\
\text { somewhat reduced relative to GTAW; } \\
\text { since electrode holder must be close to } \\
\text { the workpiece it is less adaptable than } \\
\text { SMAW for welding in difficult-to- } \\
\text { reach situations. }\end{array}$ \\
\hline $\begin{array}{l}\text { Shielded Metal Arc } \\
\text { Welding (SMAW) }\end{array}$ & $\begin{array}{l}\text { Versatile, can be used in all welding } \\
\text { positions; can be operated easily in } \\
\text { remote locations; equipment is less } \\
\text { complex, more portable, and less } \\
\text { costly than for other arc-welding } \\
\text { processes. }\end{array}$ & $\begin{array}{l}\text { Limited to manual operations; } \\
\text { electrode requires a short time to } \\
\text { begin generating a protective } \\
\text { atmosphere from the electrode flux } \\
\text { coating, and this can result in start-up } \\
\text { porosity; removal of slag required } \\
\text { between passes; visibility during } \\
\text { welding is impaired by slag; not } \\
\text { suitable for very thin sheet; electrodes } \\
\text { are sensitive to moisture pickup. }\end{array}$ \\
\hline
\end{tabular}


TABLE 12. CONTAMINATING ELEMENTS ON WELDING NICKEL-RICH ALLOYS

\begin{tabular}{|l|l|l|}
\hline \multicolumn{1}{|c|}{ Elements } & \multicolumn{1}{|c|}{ Effect/Defect } & Common Sources of Elements \\
\hline Sulfur, Carbon & Reduced corrosion resistance & $\begin{array}{l}\text { Hydrocarbons, such as cutting fluids, } \\
\text { grease, oil, waxes, and primers }\end{array}$ \\
\hline Sulfur, Phosphorus & Cracking in weld and in HAZ & $\begin{array}{l}\text { Marking crayons, paints, and } \\
\text { temperature-indicating markers }\end{array}$ \\
\hline $\begin{array}{l}\text { Lead, Zinc, Copper, and other } \\
\text { low melting point metals }\end{array}$ & Cracking in weld and in HAZ & $\begin{array}{l}\text { Tools, such as lead hammers, copper } \\
\text { hold-down or backing bars, zinc-rich } \\
\text { paint, and galvanized steel }\end{array}$ \\
\hline Shop dirt & Any of the above & Any of the above \\
\hline
\end{tabular}


TABLE 13. COMPARISON OF ROOM-TEMPERATURE TENSILE PROPERTIES OF AS-WELDED WELDMENTS AND BASE METAL OF ALLOYS C-4, C-22, AND G-3

\begin{tabular}{|l|l|l|l|l|l|}
\hline Alloy & $\begin{array}{c}\text { Thickness } \\
\text { inches }\end{array}$ & $\begin{array}{c}\text { Sample } \\
\text { Source }\end{array}$ & $\begin{array}{c}\text { Yield Strength } \\
\mathrm{ksi}(\mathrm{Mpa})\end{array}$ & $\begin{array}{c}\text { Tensile Strength } \\
\mathrm{ksi}(\mathrm{Mpa})\end{array}$ & $\begin{array}{l}\text { Elong. in 2 } \\
\text { inches-\% }\end{array}$ \\
\hline C-4 & 0.5 & Base metal & $48.6(335)$ & $116.8(805)$ & 63 \\
\hline C-4 & 0.5 & GTAW* & $68.3(471)$ & $112.7(777)$ & 40 \\
\hline C-22 & $0.25-0.75$ & Base Metal & $54(372)$ & $114(786)$ & 62 \\
\hline C-22 & 0.5 & GTAW & $65(448)$ & $114(786)$ & 47 \\
\hline C-22 & 0.5 & $\begin{array}{l}\text { GMAW } \\
\text { Short Arc }\end{array}$ & $63(434)$ & $109(752)$ & 38 \\
\hline C-22 & 0.5 & $\begin{array}{l}\text { GMAW } \\
\text { Spray }\end{array}$ & $67(462)$ & $110(758)$ & 37 \\
\hline C-22 & 0.75 & SMAW\# & $56(386)$ & $111(765)$ & 44 \\
\hline G-3 & Plate & Base Metal & $45.1(311)$ & $1004(692)$ & 58 \\
\hline G-3 & $0.5-0.75$ & GTAW & $47.3(326)$ & $95.9(661)$ & 49 \\
\hline G-3 & $0.5-0.75$ & SMAW & $52.9(365)$ & $101.8(702)$ & 42 \\
\hline G-3 & $0.5-0.75$ & GMAW & $51.1(352)$ & $98.3(678)$ & 39 \\
\hline * GTAW-Gas Tungsten Arc Welding & & \\
\hline $\begin{array}{l}\text { + GMAW-Gas metal Arc Welding } \\
\text { SMAW-Shielded Metal Arc Welding }\end{array}$ & & & \\
\hline
\end{tabular}


TABLE 14. COMPARATIVE IMMERSION PITTING AND CREVICE-CORROSION TEMPERATURES IN OXIDIZING NaCl-HCl SOLUTION*

\begin{tabular}{|l|cc|cc|}
\hline & \multicolumn{2}{|c|}{$\begin{array}{c}\text { Pitting } \\
\text { Temperature }\end{array}$} & \multicolumn{2}{c|}{$\begin{array}{c}\text { Crevice-Corrosion } \\
\text { Temperature }\end{array}$} \\
\hline \multicolumn{1}{|c|}{ Alloy } & ${ }^{\circ} \mathrm{C}$ & ${ }^{\circ} \mathrm{F}$ & ${ }^{\circ} \mathrm{C}$ & ${ }^{\circ} \mathrm{F}$ \\
\hline Alloy C-276 & 150 & 302 & 80 & 176 \\
\hline Alloy 625 & 101 & 214 & 25 & 77 \\
\hline Alloy G-3 & 75 & 167 & 25 & 77 \\
\hline Alloy G & 75 & 167 & 25 & 77 \\
\hline Alloy 255 (FERRALIUM) & 50 & 122 & 35 & 95 \\
\hline Alloy 904L & 45 & 113 & 20 & 68 \\
\hline Type 317LM Stainless Steel & 35 & 95 & 15 & 59 \\
\hline Type 317L Stainless Steel & 25 & 77 & 10 & 50 \\
\hline Alloy 825 & 25 & 77 & $5-5$ & $\leq-23$ \\
\hline Alloy 20 Cb-3 & 20 & 68 & $\leq-5$ & $\leq-23$ \\
\hline Type 316 Stainless Steel & 20 & 68 & $\leq-5$ & $\leq-23$ \\
\hline $\begin{array}{l}* 4 \% \text { NaCl + 0.1\% Fe2(SO4)3 +0.01 M HCl. Solution contains 24,300 ppm } \\
\text { chlorides and is acidic with a pH 2. }\end{array}$ & \multicolumn{4}{|c|}{} \\
\hline
\end{tabular}


TABLE 15. MINIMUM AS-WELDED MECHANICAL PROPERTIES OF WELDING PRODUCTS FOR INCOLOY ALLOY 825

\begin{tabular}{|l|l|l|l|l|}
\hline & \multicolumn{2}{l|}{ Tensile Strength } & Elong. & Hardness \\
\cline { 2 - 6 } & $\mathrm{ksi}$ & $\mathrm{Mpa}$ & $\%$ & $\mathrm{R}_{\mathrm{B}}$ \\
\hline $\begin{array}{l}\text { Inconel Welding Electrode 112 (AWS A5.11 ENiCrMo-3; } \\
\text { ASME F43; ASME SFA-5.11; UNS W86112) }\end{array}$ & 110 & 758 & 30 & \\
\hline $\begin{array}{l}\text { Inconel Welding Electrode 122 (AWS A 5.11ENiCrMo-10; } \\
\text { UNS W86022) }\end{array}$ & 115 & 793 & 40 & 100 \\
\hline $\begin{array}{l}\text { Incoloy Welding Electrode 135 (DIN 1736 EL-NiCr28Mo; } \\
\text { Werkstoff Nr. 2.4653; VdTUV 1042.00) }\end{array}$ & 85 & 586 & 30 & \\
\hline $\begin{array}{l}\text { Incoloy Filler Metal 65 (AWS A5. 14 ERNiFeCr-1; ASME } \\
\text { F45; ASME SFA-5. 14 ERNiFeCr-1; UNS N08065) }\end{array}$ & 80 & 552 & 25 & \\
\hline $\begin{array}{l}\text { Inconel Filler Metal 622 (AWS A 5. 14 ERNiCrMo-10; } \\
\text { UNS N06022) }\end{array}$ & 115 & 793 & 40 & 100 \\
\hline $\begin{array}{l}\text { Inconel Filler Metal 625 (AWS A5. 14 ERNiCrMo-3; } \\
\text { ASME F43; ASME SFA-5. 14 ERNiCrM0-3; UNS N06625 }\end{array}$ & 105 & 724 & 30 & \\
\hline
\end{tabular}


TABLE 16. COMPOSITIONS OF WELDING PRODUCTS FOR ALLOY $825^{++}$

\begin{tabular}{|c|c|c|c|c|c|c|}
\hline & $\begin{array}{c}\text { Inconel } \\
\text { Welding } \\
\text { Electrode } 112\end{array}$ & $\begin{array}{c}\text { Inconel } \\
\text { Welding } \\
\text { Electrode } 122\end{array}$ & $\begin{array}{c}\text { Incoloy } \\
\text { Welding } \\
\text { Elcctrode } 135\end{array}$ & $\begin{array}{l}\text { Incoloy } \\
\text { Filler } \\
\text { Metal } 65\end{array}$ & $\begin{array}{l}\text { Inconel } \\
\text { Filler } \\
\text { Metal } 622\end{array}$ & $\begin{array}{c}\text { Inconel } \\
\text { Filler } \\
\text { Metal } 625\end{array}$ \\
\hline $\mathrm{Ni}$ & $55.0 \mathrm{~min}^{* *}$ & Remainder & $35.0-40.0^{*}$ & $38.0-46.0^{*}$ & Remainder & $58.0 \mathrm{~min}$ \\
\hline $\mathrm{Fe}$ & $7.0 \max$ & $2.0-6.0$ & Remainder & $22.0 \mathrm{~min}$ & $2.0-2.6$ & $5.0 \max$ \\
\hline $\mathrm{Cr}$ & $20.0-23.0$ & $20.0-22.5$ & $26.5-30.5$ & $19.5-23.5$ & $20.0-22.5$ & $20.0-23.0$ \\
\hline Mo & $8.0-10.0$ & $12.5-14.5$ & $2.75-4.50$ & $2.5-3.5$ & $12.5-14.5$ & $8.0-10.0$ \\
\hline C & $0.10 \max$ & $0.02 \max$ & $0.08 \max$ & $0.05 \max$ & $0.015 \max$ & $0.10 \max$ \\
\hline Mn & $1.0 \max$ & $1.0 \max$ & $1.25-2.50$ & $1.0 \max$ & 0.50 & $0.50 \max$ \\
\hline $\mathbf{P}$ & $0.03 \max$ & $0.03 \max$ & & $0.03 \max$ & $0.02 \max$ & $0.02 \max$ \\
\hline$S$ & $0.02 \max$ & $0.02 \max$ & $0.03 \max$ & $0.03 \max$ & $0.02 \max$ & $0.015 \max$ \\
\hline $\mathbf{S i}$ & $0.75 \max$ & $0.2 \max$ & $0.75 \max$ & $0.50 \max$ & $0.08 \max$ & $0.50 \max$ \\
\hline Co & & $2.5 \max$ & & & $2.50 \max$ & $1.0 \max ^{\#}$ \\
\hline V & & $0.3 \max$ & & & $0.35 \max$ & \\
\hline $\mathbf{T i}$ & & & & $0.60-1.20$ & & $0.40 \max$ \\
\hline Al & & & & $0.20 \max$ & & $0.40 \max$ \\
\hline $\mathrm{Cu}$ & $0.50 \max$ & $0.50 \max$ & $1.0-2.5$ & $1.5-3.0$ & $0.50 \max$ & $0.50 \max$ \\
\hline $\mathrm{Nb}$ & $3.15-4.15^{+}$ & & & & & $3.15-4.15^{+}$ \\
\hline $\mathbf{W}$ & & $2.5-3.5$ & & & $2.5-4.5$ & \\
\hline Others & $0.50 \max$ & $0.50 \max$ & $0.50 \max$ & $0.50 \max$ & $0.50 \max$ & $0.50 \max$ \\
\hline
\end{tabular}


TABLE 17. APPROXIMATE MILL-PRODUCT-COST RATIO*

\begin{tabular}{|c|c|c|}
\hline Alloy & ASTM Grade & Cost ratio \\
\hline Unalloyed Ti & 2 & 1.00 \\
\hline Ti-0.3Mo-0.8Ni & 12 & 1.10 \\
\hline Ti-0.1Ru & - & 1.12 \\
\hline Ti-6Al-4V-0.1Ru & -- & 1.34 \\
\hline Ti-0.05Pd & 16 & 1.35 \\
\hline Ti-3Al-2.5V-0.1Ru & - & 1.37 \\
\hline Ti-6Al-4V-0.05Pd & 24 & 1.57 \\
\hline Ti-3Al-2.5V-0.05Pd & 18 & 1.60 \\
\hline Ti-0.15Pd & 7 & 1.90 \\
\hline Hastelloy C-276 & - & 1.90 \\
\hline * Corrected for density and for 6.3 mm plate \\
\hline
\end{tabular}


TABLE 18. RELATIVE MERITS OF Ti-GRADES 7, 12, AND 16

\begin{tabular}{|l|l|}
\hline \multicolumn{1}{|c|}{ Feature } & \multicolumn{1}{c|}{ Relative Mcrit } \\
\hline Corrosion resistance in reducing acids & Grade $16 \approx$ Grade $7>$ Grade 12 \\
\hline Pitting potential & Grade $16 \approx$ Grade $7>$ Grade 12 \\
\hline Resistance to crevice corrosion & Grade $16>$ Grade $7>$ Grade 12 \\
\hline Resistance to hydrogen absorption & Grade $16>$ Grade $7>$ Grade 12 \\
\hline Mechanical and physical properties & Grade $16 \approx$ Grade $7 \approx \approx$ Grade 12 \\
\hline Formability & Grade $16 \approx$ Grade $7>$ Grade 12 \\
\hline Weldability & Grade $16 \approx$ Grade $7 \approx$ Grade 12 \\
\hline Relative cost & Grade $7>$ Grade $16>$ Grade 12 \\
\hline
\end{tabular}


TABLE 19. PHYSICAL AND MECHANICAL PROPERTIES OF Ti-GRADE 12

\begin{tabular}{|c|c|c|}
\hline $\mathrm{Popert}$ & \multicolumn{2}{|c|}{$\mathrm{rnnaldates}$} \\
\hline \multirow[t]{2}{*}{ Yield Strength $(0.2 \%$ Offset) } & $448 \mathrm{MPa} @ 24^{\circ} \mathrm{C}$ & $65 \mathrm{ksi} @ 75^{\circ} \mathrm{F}$ \\
\hline & $414 \mathrm{MPa} @ 93^{\circ} \mathrm{C}$ & $60 \mathrm{ksi} @ 200^{\circ} \mathrm{F}$ \\
\hline \multirow{2}{*}{$\left.\begin{array}{l}50 \mathrm{ksi} \text { min. } \\
345 \mathrm{MPa} \text { min. }\end{array}\right] \begin{array}{l}\text { per ASTM } \\
\text { Specs. }\end{array}$} & $365 \mathrm{MPa} @ 149^{\circ} \mathrm{C}$ & $53 \mathrm{ksi} @ 300^{\circ} \mathrm{F}$ \\
\hline & $303 \mathrm{MPa} @ 204^{\circ} \mathrm{C}$ & 44 ksi@400 \\
\hline \multirow{4}{*}{$\begin{array}{l}\text { Tensile Strength } \\
\left.\begin{array}{l}70 \mathrm{ksi} \text { min. } \\
483 \mathrm{MPa} \text { min. }\end{array}\right] \begin{array}{c}\text { per ASTM } \\
\text { Specs. }\end{array}\end{array}$} & $538-586 \mathrm{MPa} @ 24^{\circ} \mathrm{C}$ & $78-85 \mathrm{ksi} @ 75^{\circ} \mathrm{F}$ \\
\hline & 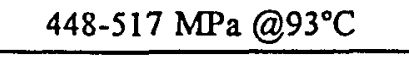 & 65-75 ksi@200 F \\
\hline & $379-469 \mathrm{MPa} @ 149^{\circ} \mathrm{C}$ & $55-68 \mathrm{ksi} @ 300^{\circ} \mathrm{F}$ \\
\hline & $324-393 \mathrm{MPa} @ 204^{\circ} \mathrm{C}$ & 47-57 ksi @400 F \\
\hline $\left.\begin{array}{l}\text { Elongation } \\
18 \% \\
18 \% \\
\end{array}\right] \begin{array}{l}\text { per ASTM } \\
\text { Specs. }\end{array}$ & \multicolumn{2}{|c|}{$\begin{array}{c}20-25 \% @ 75^{\circ} \mathrm{F}\left(24^{\circ} \mathrm{C}\right) \\
22-28 \% @ 200^{\circ} \mathrm{F}\left(93^{\circ} \mathrm{C}\right) \\
25-30 \% @ 300^{\circ} \mathrm{F}\left(149^{\circ} \mathrm{C}\right) \\
27-32 \% @ 400^{\circ} \mathrm{F}\left(204^{\circ} \mathrm{C}\right)\end{array}$} \\
\hline Reduction in Area & \multicolumn{2}{|c|}{$>25 \% @ \geq 75^{\circ} \mathrm{F}\left(\geq 24^{\circ} \mathrm{C}\right)$} \\
\hline \multirow{3}{*}{ Elastic Modulus } & $1.03 \times 10^{5} \mathrm{MPa} @ 24^{\circ} \mathrm{C}$ & $15.0 \times 10^{6} \mathrm{psi} @ 75^{\circ} \mathrm{F}$ \\
\hline & $0.99 \times 10^{5} \mathrm{MPa} @ 93^{\circ} \mathrm{C}$ & $14.4 \times 10^{6} \mathrm{psi} @ 200^{\circ} \mathrm{F}$ \\
\hline & $0.96 \times 10^{5} \mathrm{MPa} @ 204^{\circ} \mathrm{C}$ & $13.9 \times 10^{6} \mathrm{psi} @ 400^{\circ} \mathrm{F}$ \\
\hline Hardness & & HRB $95-98$ \\
\hline Charpy Impact Energy & 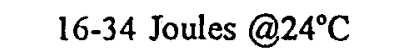 & 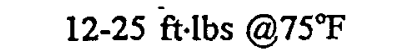 \\
\hline \multirow[t]{3}{*}{ Thermal Conductivity } & $19 \mathrm{~W} / \mathrm{m} \cdot{ }^{\circ} \mathrm{C} @ 20^{\circ} \mathrm{C}$ & 14.3 BTU/ft.hr. ${ }^{\circ} \mathrm{F} @ 68^{\circ} \mathrm{F}$ \\
\hline & $18 \mathrm{~W} / \mathrm{m} \cdot{ }^{\circ} \mathrm{C} @ 100^{\circ} \mathrm{C}$ & $13.5 \mathrm{BTU} / \mathrm{ft} \cdot \mathrm{hr} \cdot{ }^{\circ} \mathrm{F} @ 212^{\circ} \mathrm{F}$ \\
\hline & $17 \mathrm{~W} / \mathrm{m} \cdot{ }^{\circ} \mathrm{C} @ 150^{\circ} \mathrm{C}$ & 12.8 BTU/ft $\cdot h r \cdot{ }^{\circ} \mathrm{F} @ 302^{\circ} \mathrm{F}$ \\
\hline \multirow[t]{3}{*}{ Electrical Resistivity } & $51 \times 10^{-6} \mathrm{ohm} \cdot \mathrm{cm} @ 20^{\circ} \mathrm{C}$ & $20 \times 10^{-6} \mathrm{ohm} \cdot \mathrm{in} @ 68^{\circ} \mathrm{F}$ \\
\hline & $65 \times 10^{-6} \mathrm{ohm} \cdot \mathrm{cm} @ 100^{\circ} \mathrm{C}$ & $26 \times 10^{-6} \mathrm{ohm} \cdot \mathrm{in} @ 212^{\circ} \mathrm{F}$ \\
\hline & $74 \times 10^{-6} \mathrm{ohm} \cdot \mathrm{cm} @ 150^{\circ} \mathrm{C}$ & $29 \times 10^{-6} \mathrm{ohm} \cdot \mathrm{in} @ 302^{\circ} \mathrm{F}$ \\
\hline $\begin{array}{l}\text { Thermal Expansion } \\
\text { Coefficient }\end{array}$ & $\begin{array}{c}9.8 \times 10^{-6}\left({ }^{\circ} \mathrm{C}\right)^{-1} \\
\text { over } 0-370^{\circ} \mathrm{C} \text { range }\end{array}$ & $\begin{array}{c}5.3 \times 10^{-6}\left({ }^{\circ} \mathrm{F}\right)^{-1} \\
\text { over } 32-600^{\circ} \mathrm{F} \text { range }\end{array}$ \\
\hline Specific Heat (at $25^{\circ} \mathrm{C}$ ) & $544 \mathrm{~J} / \mathrm{kg} \cdot{ }^{\circ} \mathrm{C}$ & $0.13 \mathrm{BTU} / \mathrm{b} \cdot{ }^{\circ} \mathrm{F}$ \\
\hline Density (at $25^{\circ} \mathrm{C}$ ) & $4.54 \mathrm{gm} / \mathrm{cm}^{3}$ & $0.163 \mathrm{lb} / \mathrm{in}^{3}$ \\
\hline
\end{tabular}



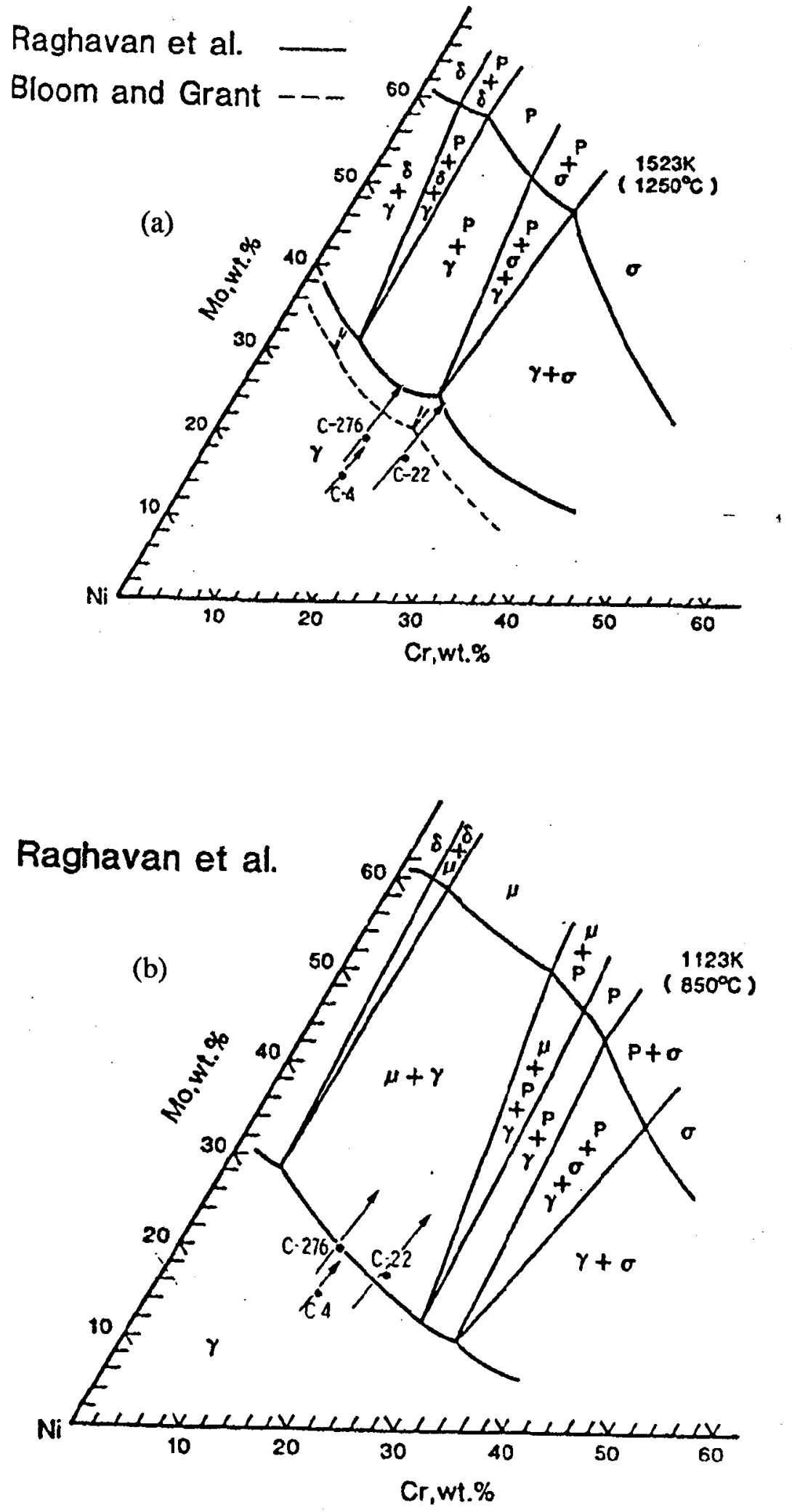

Figure 1-Isothermal sections of the Ni-Cr-Mo system showing nominal equivalent compositions and equivalent solidification profiles (arrows): (a) $1250^{\circ} \mathrm{C}$, (b) $850^{\circ} \mathrm{C}$. 


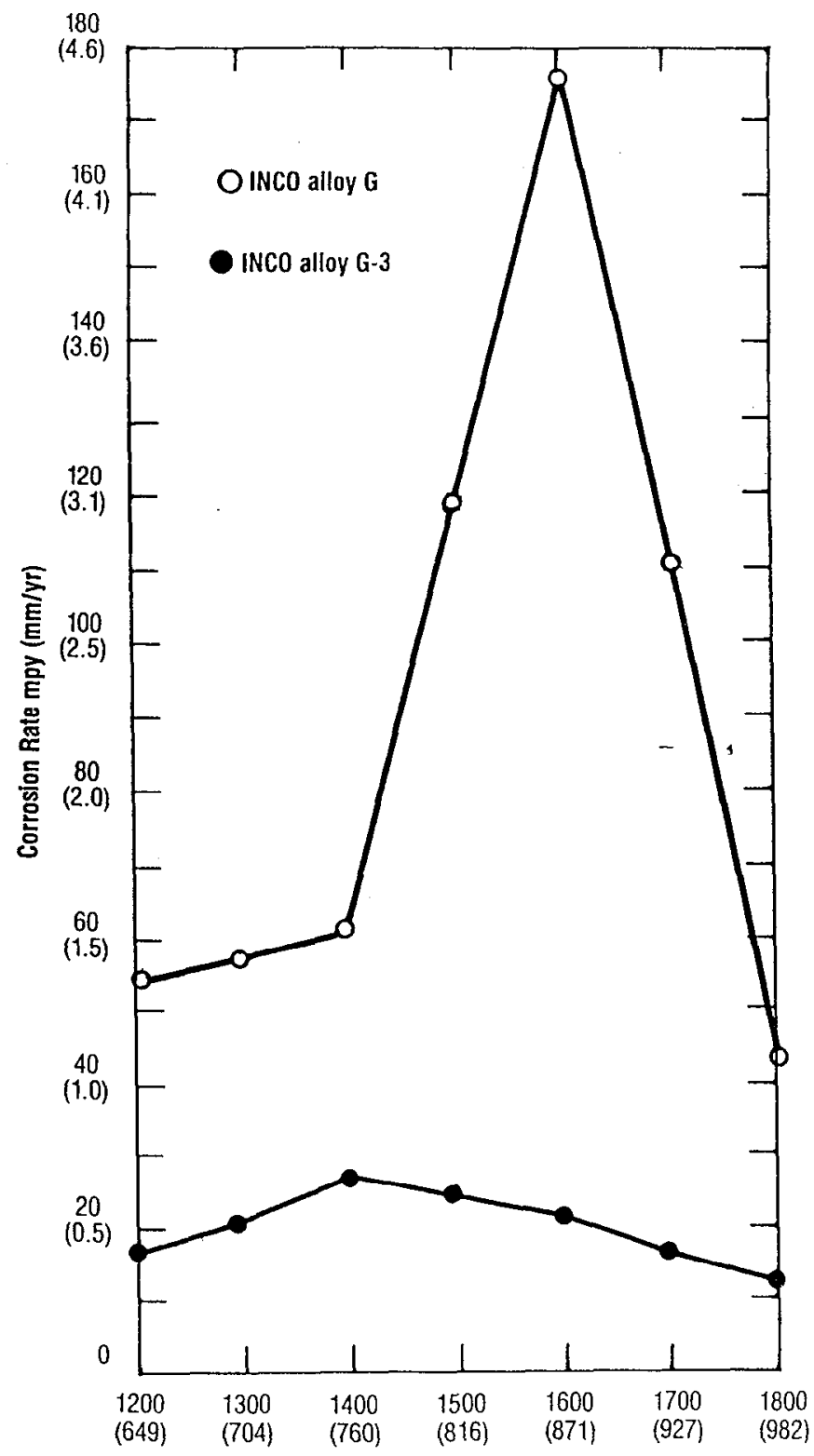

Figure 2-Effect of heat-treatment temperature on the corrosion rate of Alloys G and G-3. Test samples were heated for one hour to indicated temperatures and air cooled. Following heat treatment, samples were exposed to procedure ASTM G-28, Method A (24 hours in boiling $50 \% \mathrm{H}_{2} \mathrm{SO}_{4}$ plus $42 \mathrm{~g} / 1$ of $\mathrm{Fe}_{2}\left(\mathrm{SO}_{4}\right)_{3}$ ). 


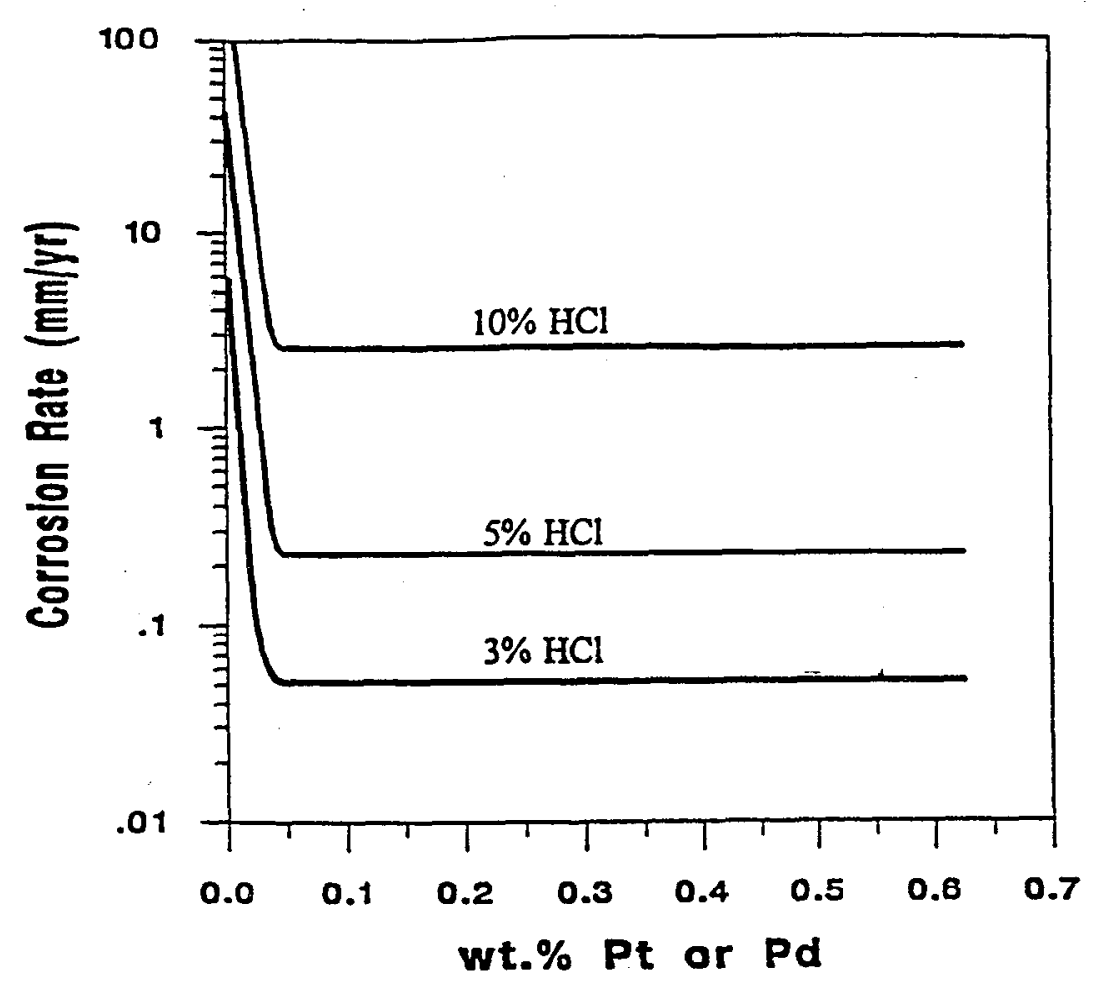

Figure 3. Effect of paladium or platinum content in titanium on the corrosion rate in boiling $\mathrm{HCl}$ solutions. 


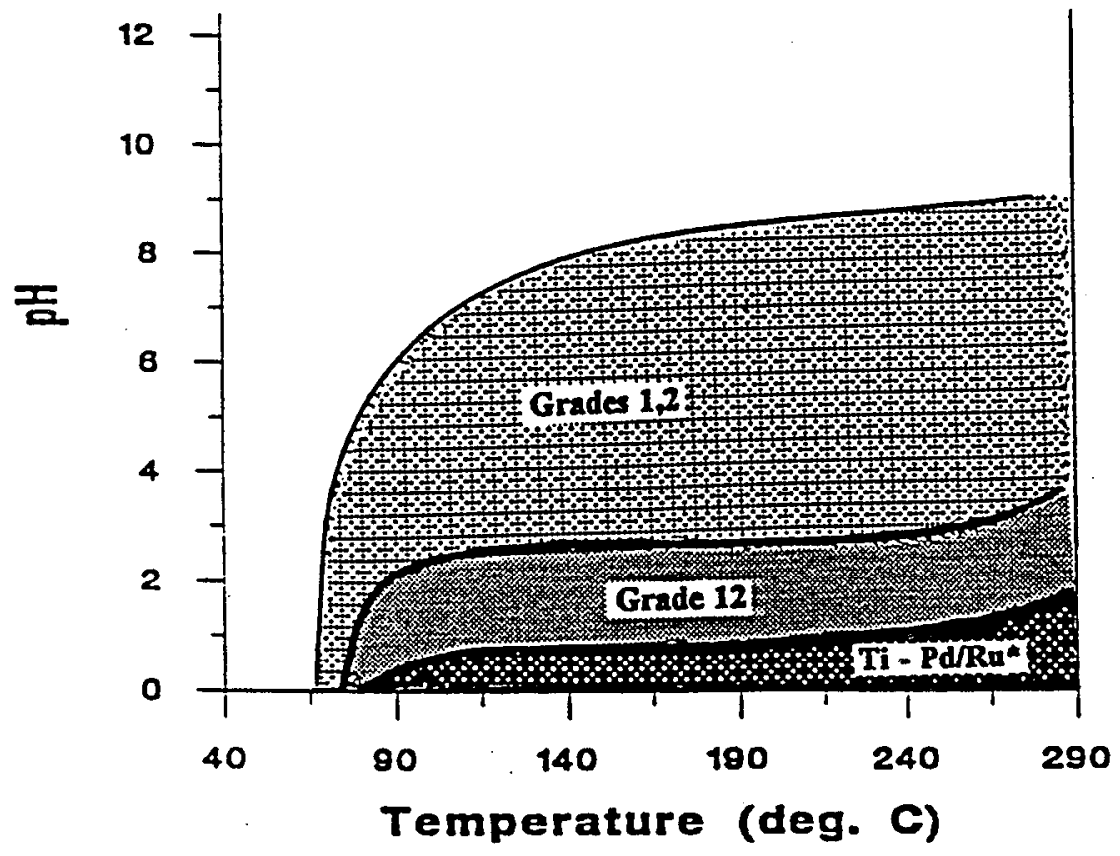

Figure 4. Temperature-pH limits for crevice corrosion of various titanium alloys in naturally aerated saturated- $\mathrm{NaCl}$ brine. Shaded areas are regions of alloy susceptibility to crevice attack. 


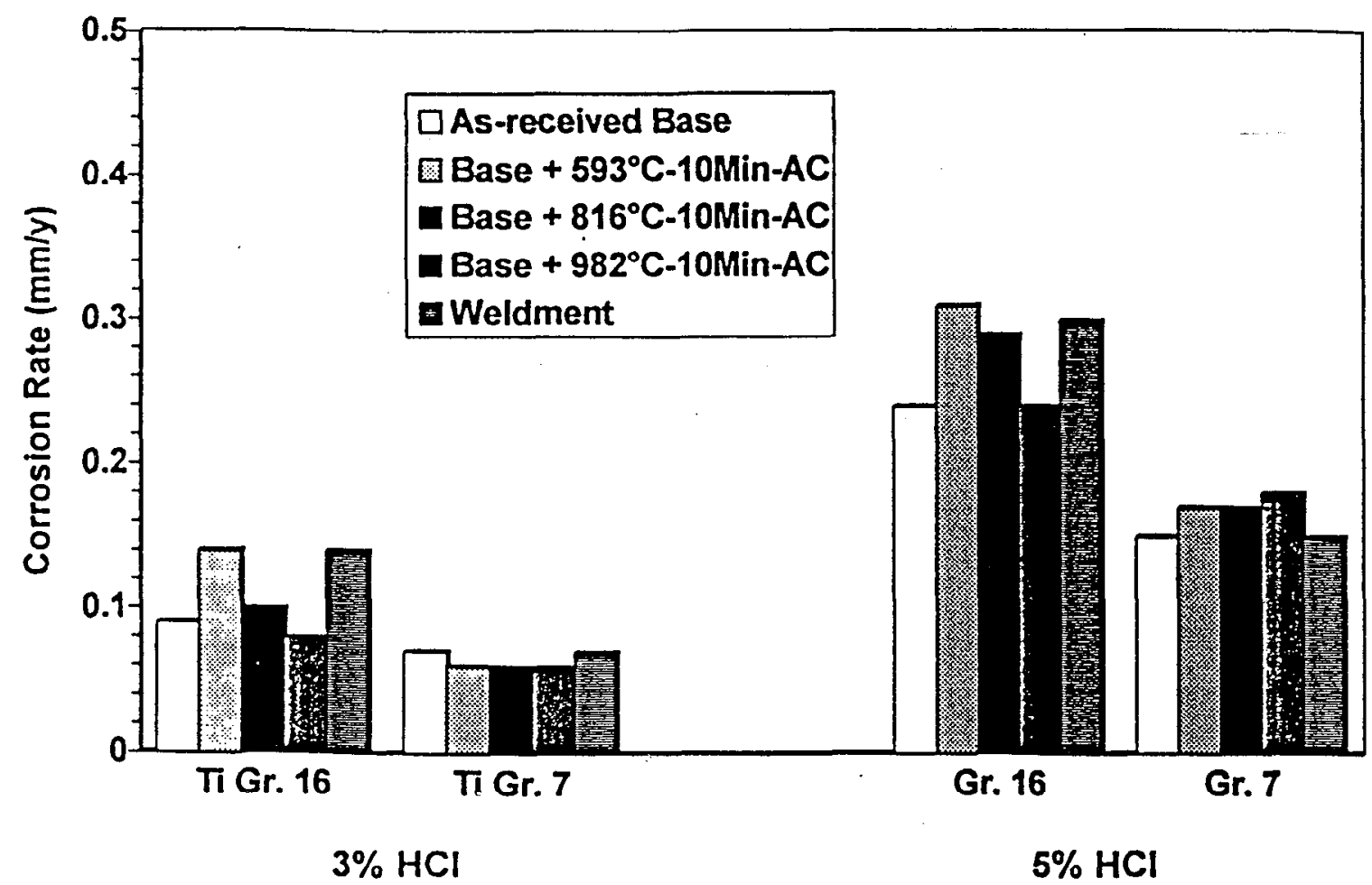

Figure 5. Effect of thermal treatments on corrosion resistance of Ti-Grades 7 and 16 in boiling $\mathrm{HCl}$. 


\section{APPENDIX}

\section{Corrosion of Superaustenitic Stainless Alloys and Ni- Cr-Mo Alloys}

The superaustenitic stainless alloys and the Ni-Cr-Mo alloys are used predominantly to resist aqueous corrosion. The following comments related to the corrosion resistance of these alloys are extracted from a publication by Stephenson. 28 The high chromium level in these alloys provides resistance to oxidizing acids. Chromium and molybdenum, together with tungsten if present, promote resistance to pitting and crevice corrosion in halide environments. High nickel and chromium contents impart resistance to halide-ion stress-corrosion cracking and, together with molybdenum (plus tungsten), diminish the susceptibility to sulfide stress-corrosion cracking. Copper, when present, tends to inhibit depasssivation under less oxidizing conditions and reinforces molybdenum in enhancing resistance to reducing acids. The carbon content is kept low to diminish the risk of sensitization during fabrication/welding. Alternatively or in addition, titanium or niobium may be used in small amounts to stabilize carbon, and in larger amounts to impart additional strength.

These alloys usually have a high resistance to uniform corrosion. The main concern is their susceptibility to localized corrosion. A relative measure of the pitting resistance equivalent (PRE) of these alloys is given in terms of composition as follows 53 :

$\mathrm{PRE}=\% \mathrm{Cr}+3.3 \times \% \mathrm{Mo}+30 \times \% \mathrm{~N}$.

Based on this expression, the PRE values for Alloys 825, 625, C-22, $\mathrm{C}-4, \mathrm{C}-276$, and 59 are $32,54,65,69,69$, and 76, respectively. 53 Corresponding value estimated for Alloy G-3 is 46 , being considerably below the values for the high molybdenum-bearing alloys, but significantly above the value for Alloy 825 .

Some of these alloys were exposed to various corrosive solutions, namely, ASTM G-28A, ASTM G-28B and "Green Death" $\left(11.5 \% \mathrm{H}_{2} \mathrm{SO}_{4}\right.$ $1.2 \% \mathrm{HCl}-1 \% \mathrm{FeCl}_{3}-1 \% \mathrm{CuCl}_{2}$ ) at several temperatures up to their boiling points. 53 The results verified the high value of PRE calculated for Alloy 59. Critical temperatures for pitting and crevice corrosion, pit and crevice depths, and uniform corrosion rates were measured. Of significance, is the superior resistance of Alloy 59 to the "Green Death" solution which attempts to simulate 
severe oxidizing chloride-acid conditions. The critical temperatures in this solution were greater than 120,120 , and $110^{\circ} \mathrm{C}$ for pitting corrosion and 110,110 , and $105^{\circ} \mathrm{C}$ for crevice corrosion for Alloys $59, \mathrm{C}-22$, and $\mathrm{C}-276$, respectively. 53 In an oxidizing solution of $\mathrm{NaCl}-\mathrm{HCl}-\mathrm{Fe}_{2}\left(\mathrm{SO}_{4}\right)_{3}(\mathrm{pH} 2$ and $24,300 \mathrm{ppm} \mathrm{Cl})$ the critical temperatures were reported as above 150 and as $150^{\circ} \mathrm{C}$ for pitting corrosion and as 102 and $80^{\circ} \mathrm{C}$ for crevice corrosion for Alloys C-22 and $\mathrm{C}-276$, respectively. The corresponding critical temperatures for Alloy 825 were 25 and equal to or less than minus $5^{\circ} \mathrm{C} .41$

Corrosion rates were reported for Alloys C-276, C-22, and 59, which had been exposed to 34 different environments consisting of different concentrations of either $\mathrm{H}_{2} \mathrm{SO}_{4}, \mathrm{HCl}$, or mixtures of the two acids at several different temperatures. ${ }^{16}$ Alloy 59 generally showed the lowest rates for the more dilute solutions of $\mathrm{HCl}$ and $\mathrm{H}_{2} \mathrm{SO}_{4}-\mathrm{HCl}$ mixtures, while Alloy $\mathrm{C}-276$ generally showed the lowest rates for the more concentrated of these two types of solutions and for all concentrations of $\mathrm{H}_{2} \mathrm{SO}_{4}$. The range of concentrations were 1 to $10 \%$ for $\mathrm{HCl}$ and 10 to $96 \%$ for $\mathrm{H}_{2} \mathrm{SO}_{4}$. Temperatures listed ranged from 52 to $107^{\circ} \mathrm{C}$, with boiling also being listed for some of the solutions. In contrast to these results, when the corrosion rates were obtained following exposure in accordance with ASTM-28 A and B, the materials in decreasing order of performance for method A were Alloys 59, C-22, C-4, and C-276; for method B, they were Alloys 59, C-22, C-276, and C-4.16

A comprehensive review of the susceptibility of the superaustenitic stainless alloys and the $\mathrm{Ni}-\mathrm{Cr}-\mathrm{Mo}$ alloys to the various forms of corrosion in different chloride media and in hydrogen environments was presented by Gdowski. ${ }^{18}$ Resistance to stress-corrosion cracking in boiling $42 \% \mathrm{MgCl}_{2}$ and $45 \% \mathrm{MgCl}_{2}$ solutions was greatly enhanced by increasing the nickel content relative to that present in conventional austenitic stainless steels. In the boiling $45 \%$ solution, Alloys 625, C-276, C-22 did not show any cracking in 1000-hour tests, while Alloy 825 with lower nickel and molybdenum contents cracked in 46 hours. This compared to failure in less than two hours for the conventional stainless steels (316 and 316L). The stress-corrosion-cracking studies quoted for a $42 \%$ solution of boiling $\mathrm{MgCl}_{2}$ performed by Copson supported these results in that no failure occurred in the testing period of 1000 hours for nickel contents above $45 \%$. A number of alloys $(304,304 \mathrm{~L}, 316,316 \mathrm{~L}$, $20 \mathrm{Cb}-3,825,20-\mathrm{Mod}, \mathrm{G}$, and $\mathrm{C}-276$ ) were tested in various $\mathrm{NaCl}$ 
solutions for stress-corrosion cracking and localized corrosion. Ubend samples were exposed for one month at $141^{\circ} \mathrm{C}$. All of the conventional stainless steels exhibited stress-corrosion cracking as well as crevice corrosion and/or pitting. None of the high-nickel alloys showed any cracking, while pitting and crevice corrosion developed in Alloys $20 \mathrm{Cb}-3$ and 825 in one of the solutions, namely, $0.8 \% \mathrm{NaCl}-0.2 \% \mathrm{H}_{3} \mathrm{PO}_{4}$. The other solutions consisted of $4 \% \mathrm{NaCl}-1 \%$ $\mathrm{H}_{3} \mathrm{PO}_{4}, 0.8 \% \mathrm{NaCl}-0.5 \% \mathrm{CH}_{3} \mathrm{COOH}, 2 \% \mathrm{NaCl}(825$ and $20 \mathrm{Cb}-3$ were not tested). Alloy 825 was reported as being subjected to uniform thinning in a $0.8 \% \mathrm{NaCl}-\mathrm{HCl}$ solution with a $\mathrm{pH}$ of 2.2. following a 10-day exposure at $141^{\circ} \mathrm{C}$.

Anodic polarizationm tests indicated that the Ni-Cr-Mo alloys (as well as titanium alloys) are susceptible to both crevice and piting corrosion in aqueous halide solutions. 41 A review of several studies on the susceptibility to crevice corrosion in various chloride media showed that Alloys C-22, C-276, and, to a lesser extent, C-4 are considerably less susceptible than other alloys $(255,316 \mathrm{~L}, 904 \mathrm{~L}$, $625,20 \mathrm{Cb}-3$, and 825) tested. For example, a ten-day exposure of Alloy 825 in $10 \% \mathrm{FeCl}_{3}$ at $25^{\circ} \mathrm{C}$ resulted in a crevice penetration of $3175 \mu \mathrm{m}$; by contrast, no crevices developed in either Alloys C-22 or C-276. In the same test, Alloy 625 showed a penetration of 76 $\mu \mathrm{m}$.

Very limited reference is made to pitting in chlorides. 18 Smooth samples of Alloys C-276 and 625 were exposed for 24 hours to a $7 \%$ $\mathrm{H}_{2} \mathrm{SO}_{4}-3 \% \mathrm{HCl}-1 \% \mathrm{FeCl}_{3}-1 \% \mathrm{CuCl}_{2}$ solution. Exposure at $25^{\circ} \mathrm{C}$ gave a corrosion rate of $7.6 \mu \mathrm{m}$ per year with no pitting for both alloys. At $102^{\circ} \mathrm{C}$, the two alloys exhibited a considerable difference in their resistance to corrosion, namely, corrosion rates of 610 and 48,060 $\mu \mathrm{m}$ per year for Alloys C-276 and 625, respectively, with pitting only in the latter alloy (which has a much lower Mo content). Similar tests on cold-worked materials (up to $50 \%$ cold work) did not result in any pitting for Alloy C-276. The critical pitting and crevice-corrosion temperatures, as measured both in a $\mathrm{FeCl}_{3}$ and in an oxidixing $\mathrm{NaCl}-\mathrm{HCl}$ solution, indicate that Alloys $\mathrm{C}-22$ and $\mathrm{C}-276$ both have a much higher resistance to pitting and crevice corrosion relative to that of Alloy 825 . For example, the critical pitting

$\mathrm{m}$ The term polarization refers to the displacement of an electrode potential from its equilibrium potential resulting in a net current. Anodic polarization measurements allows identifying the passive region and the critical pitting potential of a metal in a given medium. 
temperatures on exposure to $6 \% \mathrm{FeCl}_{3}$ for 24 hours are about 70,60 , 38,38 , and $0^{\circ} \mathrm{C}$ for Alloys C-22, C-276, 625, C-4, and 825, respectively. Potentiostatic polarization tests, whereby induced galvanic currents are obtained by applied constant voltages, showed a direct correlation between an increase in the resistance to localized attack and an increase in the molybdenum content. ${ }^{18}$

Using potentiodynamic polarization curves, which measures corrosion current as a function of a continuously increasing or decreasing applied voltage, and potentiostatic polarization curves, Caruso evaluated the relative susceptibility to pitting corrosion of $316 \mathrm{~L}$, and Alloys 625, 825, and $\mathrm{C}-22$ in simulated $\mathrm{J}-13$ well water heated to $95^{\circ} \mathrm{C}$ and containing a 1000 -fold increase in chloride content. 54 . Only Alloys 625 and C-22 showed extended ranges of passive behavior, indicating immunity in these two alloys to localized corrosion in the test environment. Visual examination of the test samples showed no localized attack on Alloy $\mathrm{C}-22$, slight crevice corrosion on Alloy 625, and both pitting and crevice corrosion for Alloy 825 and 316L. In adding a cementitious material simulating a backfill, the pitting potentials of both $316 \mathrm{~L}$ and Alloy 825 was significantly raised, thereby indicating an increase in the passive range, and with no evidence of localized corrosion. The author suggested that this was due to the formation of a $\mathrm{CaCO}_{3}$ protective film and to the resulting high $\mathrm{pH}$ value.

Lukezich and Ahluwalia performed simlar tests in simulated $\mathrm{J}-13$ well water at its nominal composition and at a 1000-fold increase in chloride content $6.4 \mathrm{ppm}$ and $6400 \mathrm{ppm} \mathrm{Cl}^{-} .22$ Tests were performed at $100^{\circ} \mathrm{C}$. Alloys $\mathrm{C}-22, \mathrm{H}-9 \mathrm{M}, 825$, and $316 \mathrm{~L}$ were evaluated. In the nominal water, $316 \mathrm{~L}$ showed unstable behavior, while the other three materials exhibited stable passivity. A current peak formed in the passive region in each of the three potentiodynamic polarization curves, which is attributed to the oxidation of $\mathrm{Mo}$ to $\mathrm{Mo}^{+6}$ with no visible damage to the samples. In the chloride-enriched water, both $316 \mathrm{~L}$ and Alloy 825 exhibited abrupt breakdown of passivity at relatively low potentials (below which oxygen evolution is expected) as well as crevice corrosion and deep pits. Alloy H-9M showed less susceptibility to localized corrosion than the above two alloys. Alloy $\mathrm{C}-22$ did not exhibit any physical change in the chloride-enriched water other than a discoloration appearing on the sample and in the liquid when the breakdown potential was exceeded. The authors state that, Alloy C- 
22 appeared to be virtually unaffected by the increase in the chloride content from 6.4 to $6400 \mathrm{ppm}$. Potentiostatic tests were made in both solutions, also at $100^{\circ} \mathrm{C}$, for Alloys $\mathrm{C}-22$ and 825 and $316 \mathrm{~L}$. The results obtained corroborated those obtained with the potentiodynamic tests.

In his report, Gdowski presented a review on the corrosion of a number of alloys in marine environments. ${ }^{18}$ Sea water is much more aggressive than $\mathrm{J}-13$ well water. Many of the same constituents are present in both environments, but, at much higher concentrations in the sea water. In addition to the high chloride contents, magnesium, which is believed to be the most aggresive cation, is present in sea water in concentrations of about two orders of magnitude greater than in $\mathrm{J}-13$ well water. $\mathrm{A} \mathrm{pH}$ of 8.1 , which is slightly more alkaline than that of $\mathrm{J}-13$ well water, was quoted for a representative sea water. Among the Ni-Cr-Mo alloys included in the review are Alloys 825, 625, and C. In offshore marine atmospheres, these alloys did not fail in ongoing stress-corrosion-cracking tests that lasted for up to 28 years. In sea-water tests of two-year duration, none of the three alloys showed any stress-corrosion cracking; however, Alloy 825 exhibited pitting and crevice corrosion, both of which were absent on Alloys 625 and C. In a ten-year sea-water test, Alloy C suffered no detectable weight loss or pitting. In Alloy 625, localized corrosion was detected only following seven years of exposure to sea water. Crevice-corrosion tests in filtered sea water at $30^{\circ} \mathrm{C}$ for 30 days were made on a number of alloys including Alloys C-276, 625, and 825 . Of the alloys tested, only Alloys 625 and C-276 were free from attack.

In a separate investigation, 18 crevice corrosion and corrosion rates of Alloy C-276 were measured in sea-water over a range of temperatures. Crevice-corrosion tests (with excess dissolved oxygen) were performed at temperatures ranging from 35 to $107^{\circ} \mathrm{C}$ for approximately 100 days, while tests for uniform corrosion measurements were performed at temperatures from 10 to $288^{\circ} \mathrm{C}$ with times from 15 to 150 days. In these tests, crevice attack was undetected and corrosion rates were very low, between 2.5 and 5.1 $\mu \mathrm{m}$ per year.

One of the more recent developments in the Ni-Cr-Mo family of alloys is a tungsten-free, low-iron $59 \% \mathrm{Ni}-23 \% \mathrm{Cr}-16 \%$ Mo material, referred to as Alloy 59. This alloy showed a higher resistance to corrosion than did Alloys C-22, C-4, and C-276 when tested 
according to both ASTM G-28A (120-hour exposure) and G-28B (24hour exposure). ${ }^{16}$ Alloy 59 also showed a relatively high resistance to sensitzation. For example, using ASTM G-28, procedure B, following an exposure of one hour at $871^{\circ} \mathrm{C}$, Alloy $\mathrm{C}-22$ was heavily attacked and showed a corrosion rate of $8.5 \mathrm{~mm}$ per year, while Alloy 59 corroded at a rate of only $0.10 \mathrm{~mm}$ per year. After a pretreatment of five hours at $871^{\circ} \mathrm{C}$, the rates were 40.2 and $0.43 \mathrm{~mm}$ per year, respectively. Intergranular penetration of Alloy 59 was also considerably less than that observed for the other $\mathrm{Ni}-\mathrm{Cr}-\mathrm{Mo}$ alloys. The time-temperature-precipitation diagram for the onset of precipitation at grain boundaries and within the grains for Alloy 5916 can be superimposed on the diagram reported for Alloy C-22.18 This is seen by comparing the curves in Figure A-1a with those in Figure A-1b. Microprobe analysis following an exposure of 100 hours at $900^{\circ} \mathrm{C}$, corresponding to the maximum precipitation rate, indicated the precipitate in Alloy 59 to be the Mu phase. ${ }^{16}$ In a recent review article on nickel-based alloys, Agarwal and Herda indicated that Alloy 59, in having the highest pitting resistance equivalent and the lowest iron content has improved corrosion resistance over Alloys C-22 and C-276 as well as over many other alloys. The elimination of tungsten and the reduction of iron to about $1 \%$ gives the alloy superior thermal stability. With the combination of high chromium $(23 \% \mathrm{Cr})$ and high molybdenum $(16 \%$ Mo) contents, the authors claim that Alloy 59 exhibits one of the highest critical pitting and crevice-corrosion temperatures. 55

\section{Failure of Ni-Cr-Mo Alloys in Hydrogen Environments}

In the annealed condition, the Ni-Cr-Mo alloys are not susceptible to hydrogen embrittlement $(\mathrm{HE})$. The cold-worked alloys are also not susceptible to $\mathrm{HE}$ unless either galvanically coupled to a less noble material or cathodically charged with hydrogen. 56 Failure by HE is distinguished from failure by stress-corrosion cracking in that the former involves the absorption of atomic hydrogen at the cathode, while the latter involves anodic dissolution. It is possible, that at some point in time the highly corrosion-resistant barrier wall would come in contact with the corrosion-allowance alloy. In a wet environment, under sufficient stress, and with the evolution of hydrogen at the cathodic barrier, $\mathrm{HE}$ of the corrosion-resistant alloy could occur if it were in the cold-worked condition or if part of the structure had experienced local plastic deformation. Gdowski points out that studies on HE in the Ni-Cr-Mo alloys were focused primarily 
on the cold-worked and/or aged conditions that provided the high strength levels required for oil-field operations. ${ }^{18}$ The strength levels of these alloys in the mill-annealed condition, however, are sufficient to meet the design requirements for the proposed waste containers.

The degree of cold work, the temperature and time of aging, the stress level, the direction of stressing, alloy composition, and the environmental composition all effect the susceptibility to HE.

Gdowski presents the results of a number of studies showing the effects of these factors on HE in Alloys C-276, C-4, and 625.18. Samples were stressed close to their yield strengths. The tests were conducted in the NACE Solution (aqueous solution of $5 \% \mathrm{NaCl}-$ $0.5 \%$ acetic acid saturated with $100 \% \mathrm{H}_{2} \mathrm{~S}$ gas) recommended for testing the susceptibility to HE. Tests were performed either under hydrogen charging or galvanic coupling. By galvanic coupling the test metal to a less noble metal, the test metal becomes cathodic to the less noble metal with the evolution of hydrogen at its surface. This is corrosion-resistant alloy coming in contact with the corrosion-allowance alloy with hydrogen being generated at the surface of the former alloy.

Of the three alloys, Alloy C-276 generally appeared to exhibit the greatest resistance to $\mathrm{HE}$ and Alloy C-4 the least. The effect of impurites is unclear, although it is suggested that impurities will adversely affect HE. 18 Phosphorus appears to have a detrimental affect by segregating at grain boundaries during aging. The susceptibility to HE increased with the degree of cold work. Samples stressed parallel to the rolling direction were shown to be more resistant to $\mathrm{HE}$ than were those stressed transversely. An increase in either aging time or aging temperature of cold-worked materials resulted in a decrease in the time to failure. Based on limited information, it appears that with an increase in test temperature the alloys become less susceptible to HE. The effect of temperature $\left(25\right.$ to $149^{\circ} \mathrm{C}$ ) is attributed to the hydrogen becoming more dispersed throughout the lattice with an increase in temperature in contrast to their concentration at defect sites at the lower temperatures. The presence of $\mathrm{H}_{2} \mathrm{~S}$ in the test solution increases the susceptiblity to $\mathrm{HE}$. It is suggested that $\mathrm{H}_{2} \mathrm{~S}$ promotes the absorption of atomic hydrogen into the lattice. 


\section{ADDITIONAL COMMENTS ON CORROSION OF TITANIUM AND ITS ALLOYS}

Gdowski and Ahluwalia recently published a review on the physical metallurgy, mechanical and physical properties, and corrosion characteristics of titanium and of slightly alloyed titanium alloys. 45 The extensive amount of data available on Ti-Grade 12 indicates that this material is not susceptible to stress-corrosion cracking at naturally occurring potentials in various brines. The alloy is particularly well suited to service in the chemical industry where the environment is either mildly reducing or varying between oxidizing and reducing.

Ti-Grade 12 is claimed to possess superior resistance to sweet and sour chloride brines at high temperatures. 46 It is commonly used in a number of applications where crevice corrosion is of some concern. It is resistant to crevice corrosion and pitting in concentrated $\mathrm{NaCl}$ brines up to at least $260^{\circ} \mathrm{C}$ for $\mathrm{pH}$ values equal to or greater than three. It is fully resistant to sulfides, $\mathrm{H}_{2} \mathrm{~S}$, and elemental sulfur to at least $260^{\circ} \mathrm{C}$. Its critical pitting and crevice corrosion temperatures, determined by ASTM G-48, method B, are above $120^{\circ} \mathrm{C}$ It is fully resistant to cracking and localized attack on testing according to ASTM G-44. Crevice corrosion, however, can occur in very restricted crevices at low $\mathrm{pH}$ values in sodium chloride solutions at elevated temperatures. The susceptibility to crevice corrosion in $\mathrm{NaCl}$ solutions increases with increasing temperature, increasing chlorideion concentration, decreasing dissolved oxygen, and decreasing $\mathrm{pH}$ values. In chloride solutions with a neutral $\mathrm{pH}$, crevice corrrosion of titanium has not been observed below $120^{\circ} \mathrm{C}$. In saturated $\mathrm{NaCl}$ brines, the substitution of Ti-Grade 12 for Ti-Grade 2 greatly extends the resistance to crevice corrosion to higher temperatures and lower $\mathrm{pH}$ values. The use of Ti-Grade 7 will allow exposures to still lower $\mathrm{pH}$ values and /or higher temperatures for the same corrosion rates in these brines (Fig. A-2). 57

In Ti-Grade 12, there is no significant difference in the corrosion-rest potentials between base metal, weld metal, and the heat-affectedzone metal and, therefore, there should be no intergalvanic effects in weldments of this alloy. 46 However, under marginal or active corrosion conditions, the weldment can experience an accelerated corrosive attack depending on alloy composition. The increase in impurity content (iron, sulfur, and oxygen) associated with the coarse 
transformed beta microstructures weldments is a factor in this acceleration. Generally, weldments of Ti-Grade 12 exhibit corrosion resistance similar to the unwelded metal.

Schutz and Xiao compared the corrosion resisistance of Ti-Grade 16 with that of several other titanium grades including Ti-Grades 7 and 12.42 They obtained nearly equivalent results for Ti-Grades 7 and 16 with respect to corrosion resistance to dilute reducing acids and to resistance to acidic halide crevice attack. The corrosion rate on exposure to a number of different acids, both reducing and oxidizing, were evaluated as a function of acid concentration. For example (Fig. A-3), at low concentrations of boiling $\mathrm{HCl}$ solutions, Ti-Grades $12(0 \%$ $\mathrm{Pd})$ and $16(.05 \% \mathrm{Pd})$ exhibited essentially the same resistance to general corrosion as did Ti-Grade $7(0.15 \% \mathrm{Pd})$. At about $1,5 \% \mathrm{HCl}$, the corrosion rate of Ti-Grade 12 rises above that of Ti-Grade 7 , while the corrosion of Ti-Grade 16 only begins to rise above that of Ti-Grade 7 at about $3.5 \mathrm{wt} \% \mathrm{HCl}$. At the higher concentrations, however, Ti-Grade 16 becomes only slightly more subject to attack relative to Ti-Grade 7 . The corrosion rates at $2 \mathrm{wt} \% \mathrm{HCl}$ are 0.06 , 0.06 and $0.75 \mathrm{~mm}$ per year for Grades 7,16 , and 12, respectively; at $6 \mathrm{wt} \% \mathrm{HCl}$, the rates are 0.23 and $0.4 \mathrm{~mm}$ per year for Ti-Grades 7 and 16 , respectively.

Crevice corrosion tests in both chlorinated and non-chlorinated oxidizing brines, which included $\mathrm{pH}$ levels as low as 1.0, did not reveal any attack of either Ti-Grades 7 or 16 . Samples were exposed for 30 days at temperatures up to $260^{\circ} \mathrm{C}$. Ti-Grade 12 was not evaluated. In a separate crevice-corrosion investigation quoted by the authors, 42 samples were exposed at 100 and $200^{\circ} \mathrm{C}$ for up to 1000 hours. No incidence of crevice attack was reported for both TiGrades 7 and 16, whereas, all samples of Ti-Grade 12 were attacked. 


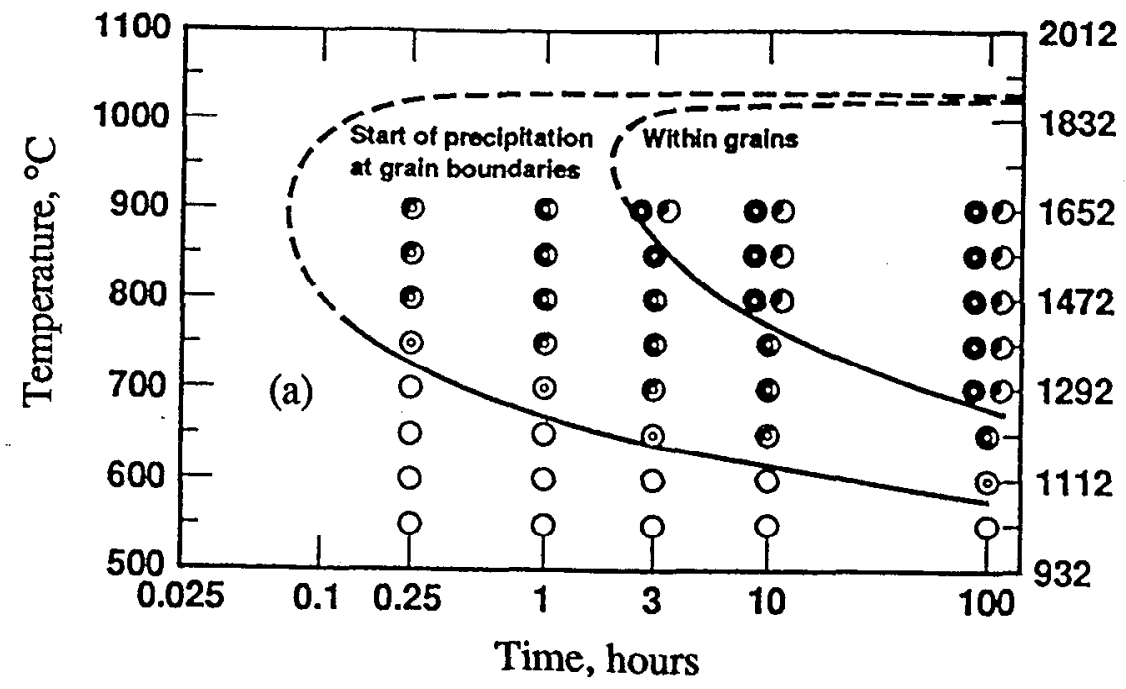

O Free from preclpitates

- Precipitation starting at grain boundarles

If Some grain boundary precipitation

- Grain boundary precipltation still Incomplete

Precipitation covers grain boundaries completcly

O Some precipitation within the grains

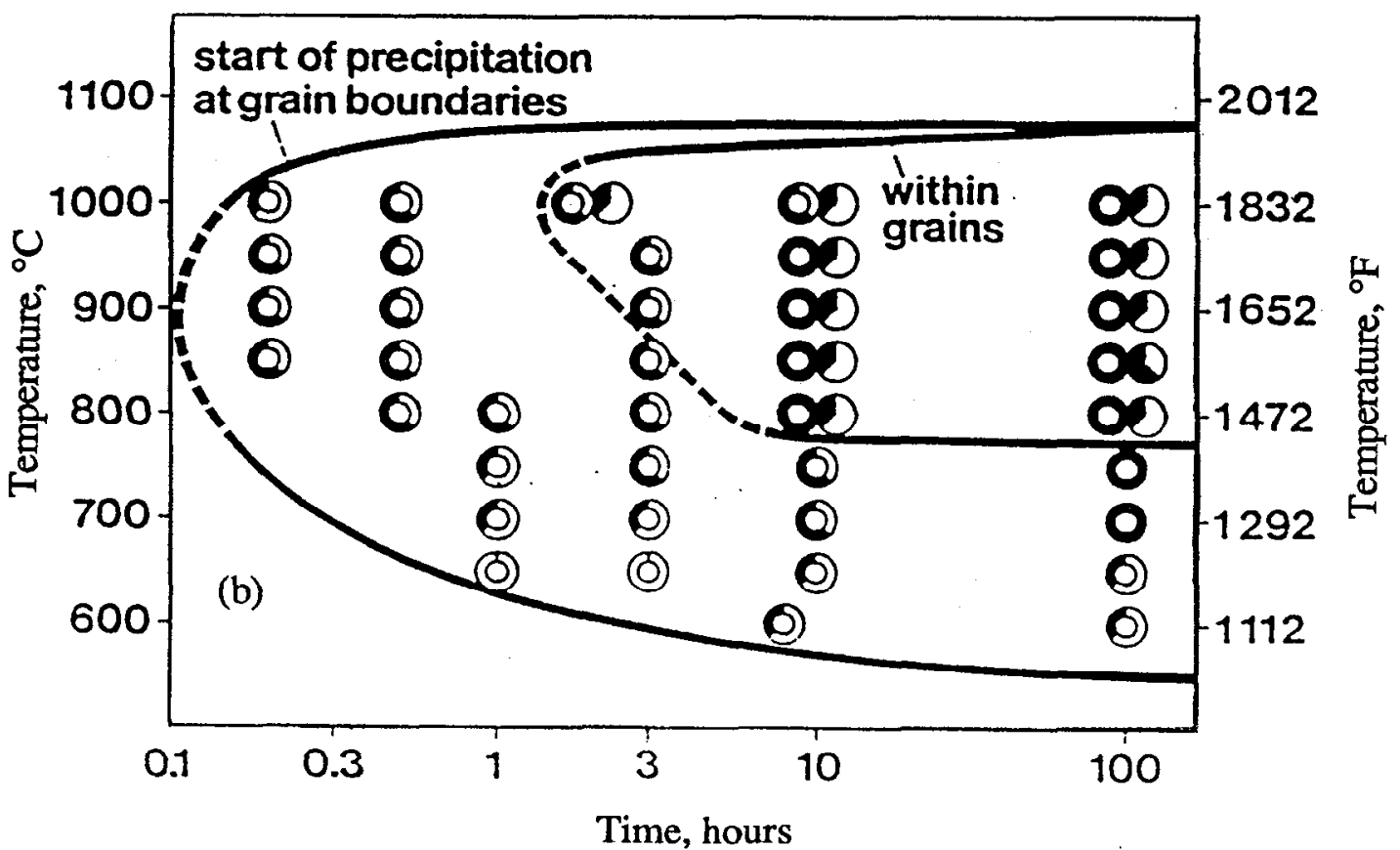

Figure A-1 - Isothermal time-temperature-precipitation (TTP) diagrams for (a) Alloy C-22 and (b) Alloy 59. 


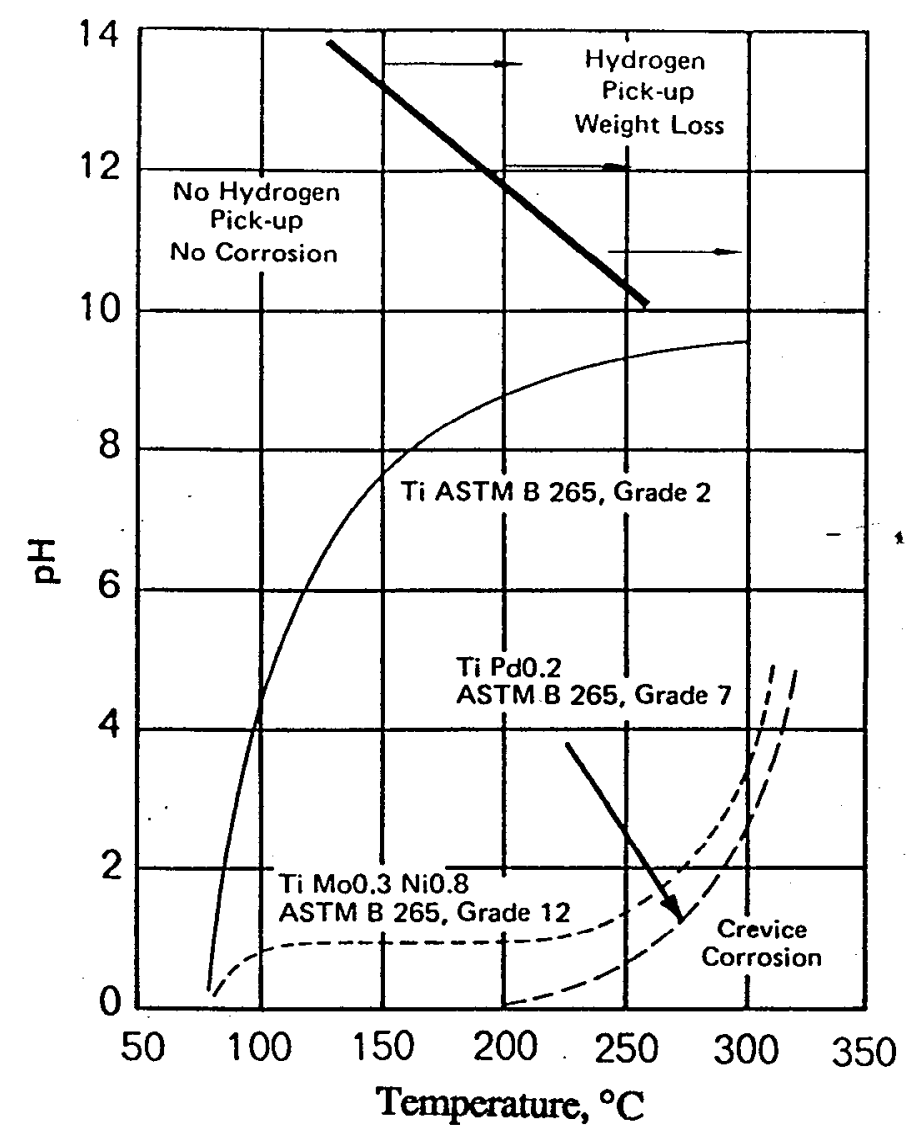

Figure A-2 - Corrosion resistance of titanium and titanium alloys in saturated $\mathrm{NaCl}$ brines. 


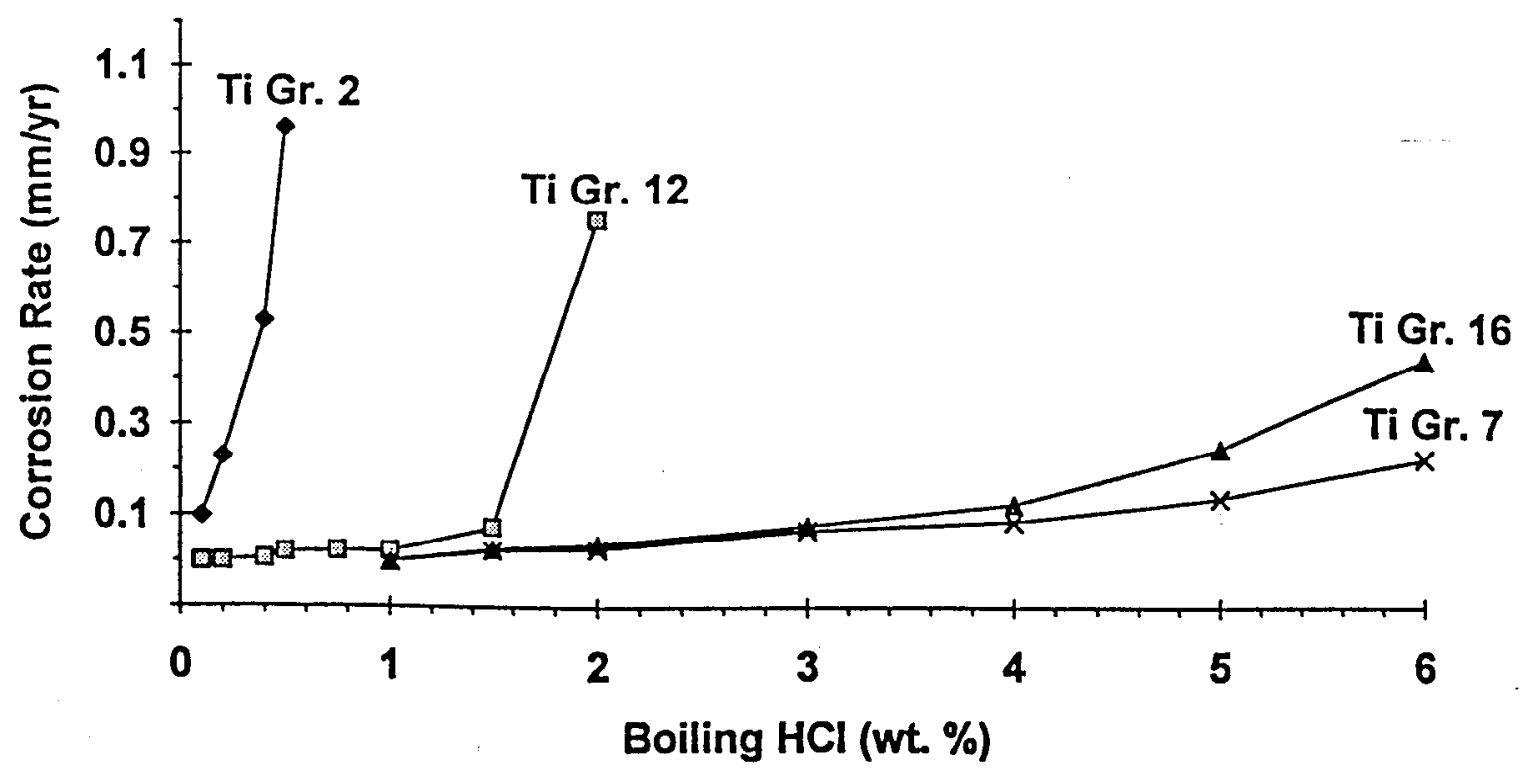

Figure A-3. Corrosion-rate profiles for Ti-Grade 7 and Ti-Grade 16 in boiling $\mathrm{HCl}$ solutions. 